\section{$32 / 1$}

NAT. HIST. JUR.

\section{IIIINOIS}

atural

\section{Iistory Surves BULLFTIN}

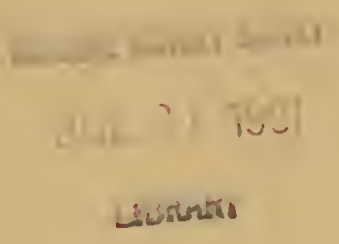

Waterfowl Populations and the Changing Environment of the Illinois River Valley nk C. Bellrose

d L. Paveglio, Jr.

iald W. Steffeck
Dsgogito.t.

JUL \& \& 1981

HNIV. Ut It HERAT.

oflow

TE OF ILLINOIS

INOIS INSTITUTE OF NATURAL RESOURCES

ITURAL HISTORY SURVEY DIVISION

BANA, ILLINOIS

VOLUME 32, ARTICLE 1

AUGUST 1979 



\section{ILLINOIS}

\section{atural Fistory Survey \\ BULLETIN}

\section{Waterfowl Populations and the \\ Changing Environment of the Illinois River Valley}


Frank Real, M.S., Chairman; Thomas Park, Ph.D., Riology; L. I. Sloss. Ph.D. Geology; H. S. Gutowsky, Ph.D., Chemistry; STANLEY K. SHAPIRo, Ph.D., Forestry; IV. L. EveritT, E.E. Ph.D. Retresenting the President of the University of Illinois; JOHN C. GuYoN, Ph.D., Representing the President of Southern Illinais University.

\section{NATURAL HISTORY SURVEY DIVISION, Urbana, Illinois}

\section{SCIENTIFIC AND TECHNICAL STAFF}

George Sprucel, JR., Ph.D., Chief

AliCE K. ADAMs, Secretary to the Chief

\section{Section of Economic Entomology}

WILLiam H. LuCKMANN, Ph.D., Entomologist and Head

JAMES E. APPLEBY, Ph.D., Entomologist

EDWARD J. ARMBRUST, Ph.D., Entomologist

MIARCos Kogan, Ph.D., Entomologist

RONALO H. MEYER, Ph.D., Entomologist

STEVENGON MLORE, III, Ph.D., Entomologist, Extension

MICHAEL E. IRWIN. Ph.D., Associote Entomologist

Donaco E. Kuhl.man, Ph.D., Associote Entomologist, Exterision

JOSEPH V. MADDox, Ph.D., Associate Entomologist RoBert D. PAusch, Ph.D.. Assorinte Entomolngist Roscoe RANDezl, Ph.D., Associnte Entomologist, Extension

WILLIAM G. RUESINK, Ph.D., Associnte Entomologist JOHN K. BOUSEMAN, M.S., Assistant Entomologist Catherive EastMan, Ph.D.. Assistont Entomologist CATHERIVE EASTMAN, Ph. Assistont Entomologist ALLAN FELSOT. Ph.D., Assistont Entomologi

CLARENCE E. White. B.S., Assistant Entomologist Luis R. Zavaleta, Ph.D., Assistant Entomologist KEVIV D. BLACK, M.S. Assisiant Specinlist, Extension Davio A. Gentry, Mi.S., Assistant Sperialist, Extension John Lublinkhor, Ph.D., Assistant Sperialist, Extension

KFVIN STEFFEY, Ph.D., Assistant Specinlist, Extension STEven Troester, M.E., Assistant Systems Engineet JEAN G. WILSON, B.A., Supervisory Assistant Lester WEe, Ph.D.. Assistant Professional Scientist Chartes G. HelM, M.S., Assistont Supportive Scientist STEPHEN ROBERTS, B.S., Assistont Supportive Scientist JoHN T. SHAw, B.S., Assistant Supportive Scientist DANIEL SHERROD, is.s. Assistant Suptortive Scientist DANIEL SHERROD, HAIE, Junior Professional Scientist ROBERT J. BARNEY, B.S., Research Assistant Victoria BRUNJEs, B.S., Research Assisfant MICHAEL BURKE, M.S., Researrh Assistant TzU-SUan ChU, M.S., Research Assistant Marion Farris, M.S., Research Assistant JANET HARRY, BS Research Assistant JENNY KOGAN. M.S., Research Assistant JENNY KOGAN. M.S., Research Assistant SUSAN POST, B.S., Researrh Assistant
FRANK RE.SS, B.S., Research Assistont BarRara STANGER, B.S., Research Assistant JO ANN AUBLE, Teclinical Assistant

Ellen Brewer. M.S., Compuler Programmet Howarn OJalvo, M.S., Computer Programmer

\section{Section of Botany and Plant Pathology}

Claus Grunwald, Ph.D., Plant Physiologist and Ilead Eugene Himelick, Ph.D., Plant Pathologist

Dan NeEly, Ph.D., Plant Pafhologist

D. F. SCHOENEWE ISS, Ph.D., Plant Pathologist J. Leinno Crane, Ph.D.. A Assoriate Myrologid KENNETH R. ROBERTSON, Ph.D.. Assistant Taxonomist BETTY NFISON, Assistant Supportive Scientist GENE E. REID, Junior Professional Scientist JAMES E. SERGENT, Creenhouse Superintendent PATRICIA O'BRYAN, B.S., Resentrh Assistant Rorert A. Harrison, Teclinical Assistant

\section{Section of Aquatic Biology}

ROBERT W. GORDEN, Ph.D., Aquatic Riologist and Head

D. Homer Buck. Ph.D.. Aquatic Riologist

WurLiam F. CHILders, Ph.D.. Aquatic Biologist

R. WEIDON LARIMORE, Ph.D. Aquntic Biologist

Robert C. HILTiBRan, Ph.D., Biochenist

ALzison Bricham. Ph. D.. Associate Aquatic Biologist

WARREN U. Briciam, Ph.D., Associale Aquatic hiologist

Ruchard F. Sparks, Ph.D., Associnte Aquafic Riologist Johv Traneutut.t, Ph.D., Associnte Aquatic Biolngist KEN I.URINSKit, P'h.D., Assistant Aquatic Biologist Tro W. STORCK. Ph.D., Assistant Aquntic Biologist Richitro J. Batr, M.S. Assistant Supportive Srientist
DEE A. MíCormick, M.S. Junior Professionnl Srientist DIE A. MCCORMICK, M.S. Junior Professional
EUGENe SONS, Junior Professional Scientist JANA I.Ee White, M.S., Junior Professionol Scientist Davio P. PHutr. P'h.D., Resentch Assorinie STEPHEN W. WAIE, M..S.. Resentch Assorinie HARRY W. BERG.ALANV, B.S., Reseatele Assistont

CONSULTANTS ANI) RESEARCH AFFIIATES: SYSTHMTIG FNtomology, ROnFICK R. IRWIN. Chirngo,

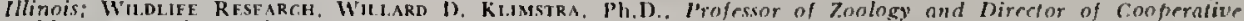

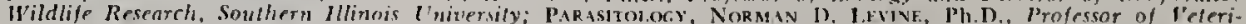

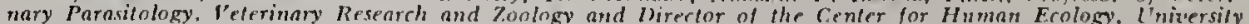

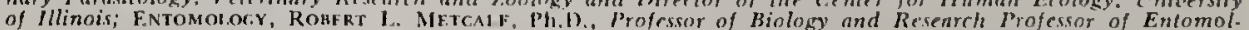

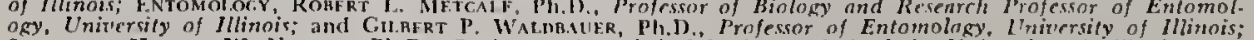
Statistics, Horace W. Norton, Ph.D., Professor of Statisticnl Design and dnalysis, University of Illinois.
Dale BurketT, B.S., Research Assistant KURT T. ClEMENT, B.S. Reseatch Assistant LARRY W. Coutant, M.S., Reseorch Assistant W'illiam Kraus, M.S., Research Assistant Richard KRAUSE, MI.S., Research Assistant SARAH LIEHR, M.S., Research Assitiont THOMAS SKELLy, MiS. Reseorch Assistant StF.pHeN O. Swade ver, M.S., Research Assistant BKICE TAUBERT, Ph. D., Reseorch Assistant CARL AloE, B.S., Terhnical Assistant Elmer Atwood. B.S. Technical Assistant Paul. Beaty, Ph. D., Technical Asristant BILL DIMOND, B.S., Techrical Assistant
KATHRYN F.wINC., B.S. Technical Assistant IFFE HUTTON. B.S.. Technicol Assistont Phildp Mankin, Techrical Assistant

DAN MYRICK, B.S., Techniral Assistant

F. J. PARTENheimer, B.A.. Technical Assistant R. DAN SALLEE, R.S. Technical Asristont IENS SANDBERCER, M.S., Technical Assistant JOHY J. Suloway. B.S. Tecliniral Assistant Gary L. WarRev. B.S. Technical Assistan! MARK I. WETZEL, B.S., Technicol Assistant

\section{Section of Faunistic Surveys and} Insect Identification

Wallace E. LABERcE. Ph. D., Insed Taxonomist and Head

Georce L. Goderey, Ph.D., Associnte Taxonomist Larry Mi. Par.e. Ph.D., Associote Toxonomist JoH, D. UnzICKER, Ph.D., Asrociate Taxonomist DONALD W. WERB, M.S., Associnte Taxonomist

\section{Section of Wildlife Research}

Gen C. Sanoerson, Ph.D.. Mildlife Specialist and Head

Frank C. Bfllrose, Sc.D., Wildlife specialist William R. EDwaros, Ph.D. Wildlife specinlist IEAN WV. GRABER, Ph.D.. H'ildlife Specinlist RICHARD R. GRABER, Ph.D., IVildife Specinlist HARoIn C. Hansov. Ph.D., W'ildlife Specialist
W. W. Cochran, JR., B.S., Associate Wildlife Specialsst Chitres M. Nixon, M..S., Assorinte Wildlife specialist KENNFth E. SMIth, Ph.D., Associate Chemisi Ronald 1.. Westemeier, il.S., Associate Wildlife

IONNIE P. Hansen, Ph.D. Asristant Wildlice Specialist STEPHEN P. HAVERA, Ph.D.. A sistant W'ildlife

RoRER D.. WARver, M.S. Assistant Wildlife Speciolist ROAERT D. Cromptov, Junior Professional Scientis RONALD E. DUZIN, Junior Professional Srientis F.v STEg.e. B.S.. Junior Professional Scientist ELFANORE Wutsov, Junior Professional Scirntist

\section{Supporting Services}

W'um, C. Dutiman, Property Control and Trust Arounts

Patty L. Duzan, Payroll and Personnel

ROAERT O, Elt.1s, Assistant for Operotions

I.ARRY 1). Gross. Operations Assisiant

Cur Lusk. Mailing and Distribution Services MFLWIN F. SCHWARTz, Fiscol Officer

\section{Publications and Public Relations}

RoRr r M . ZFWAnsk, M.S., Technical Edilot SHIRtFy MCCiflisN, B.S., Assistant Terhmienl Editor L.COYD LEMERF, Trelinical Mlluserater

C.eSt.IE. WOODRUM, Technical Pholocropher

\section{Technical Library}

DORIs 1. Sthe ETE, M.S.I..S. Terhnirnl Librarinn Movica liss, Library Clerk 1.ANCE PERRY, M.S., Research Assistant She ILA Magre, B.S.. Terhnical Assistant BERNICE P. SWEeney, Junior Professional Scientist 


\section{CONTENTS}

GEOLOGICAL HISTORY ..

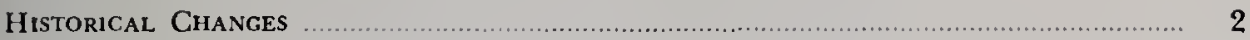

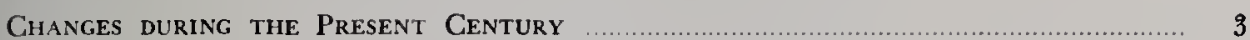

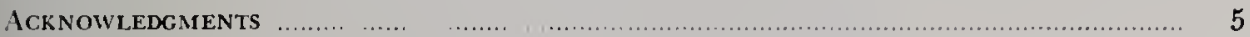

METHODS

Sedimentation

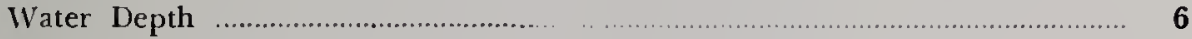

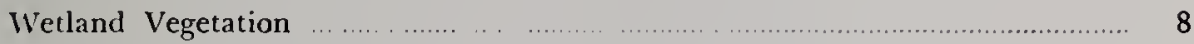

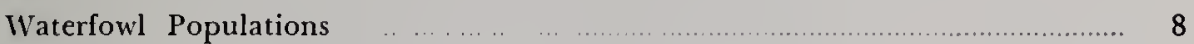

Moist-Soil Water-Level and Water-Stability Indices _................................. 8

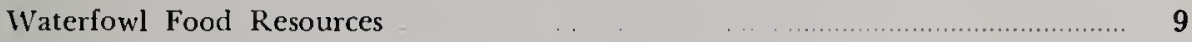

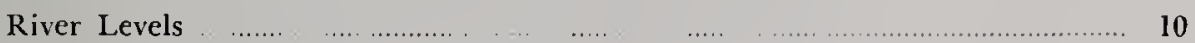

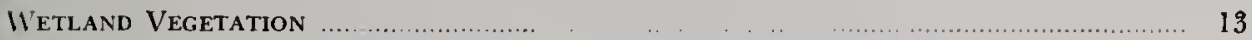

Evaluation of the Severance of Lakes from the River . .............................. 20

Evaluation of Seasonal Changes in Bottomland Lake Water Levels ............... 20

Effects on Moist-Soil Plants

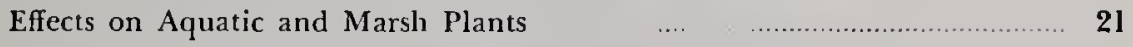

Lake Chautauqua .....

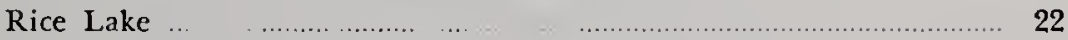

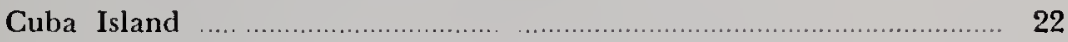

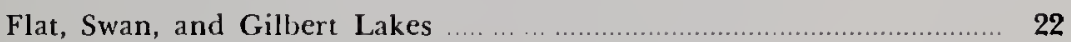

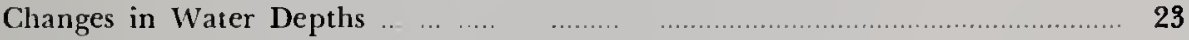

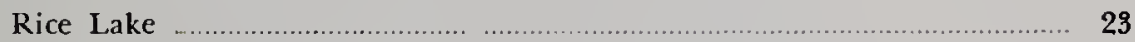

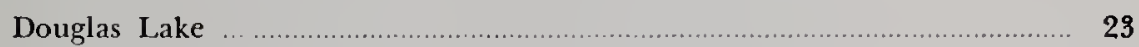

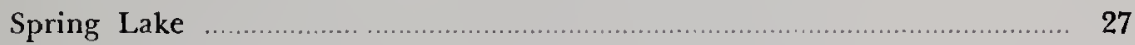

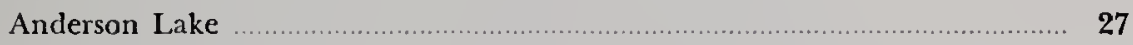

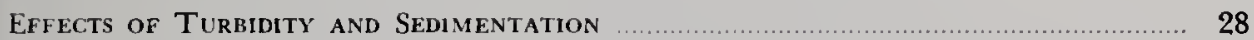

EfFects of Food Resources on Fali. Waterfowl Populations ….......................... 34

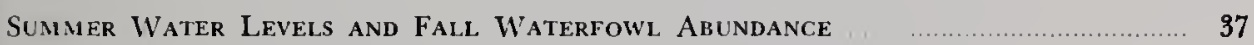

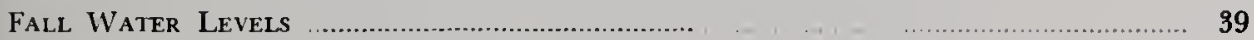

Water Levels in Relation to the Duration of Stay of Ducks ............................ $\$ 9$

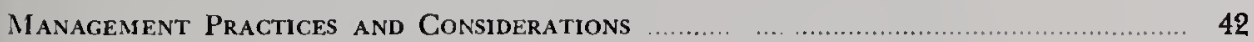

DisCUSSION

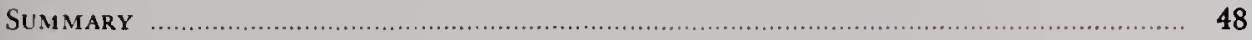

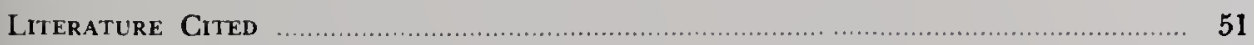

List of Comimon and SCIEnTIFIC Names …

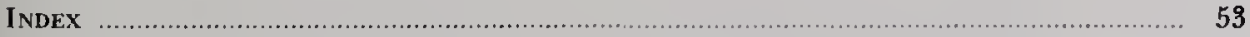

This report is published by authority of the State of Illinois. It is a contribution from the Section of Wildlife Research of the Illinois Natural History Survey.

Dr. Frank C. Bellrose is a Wildlife Specialist and Fred L. Paveglio, Jr., and Donald $\boldsymbol{W}$. Steffeck are Research Assistants in the Section of Wildlife Research. 


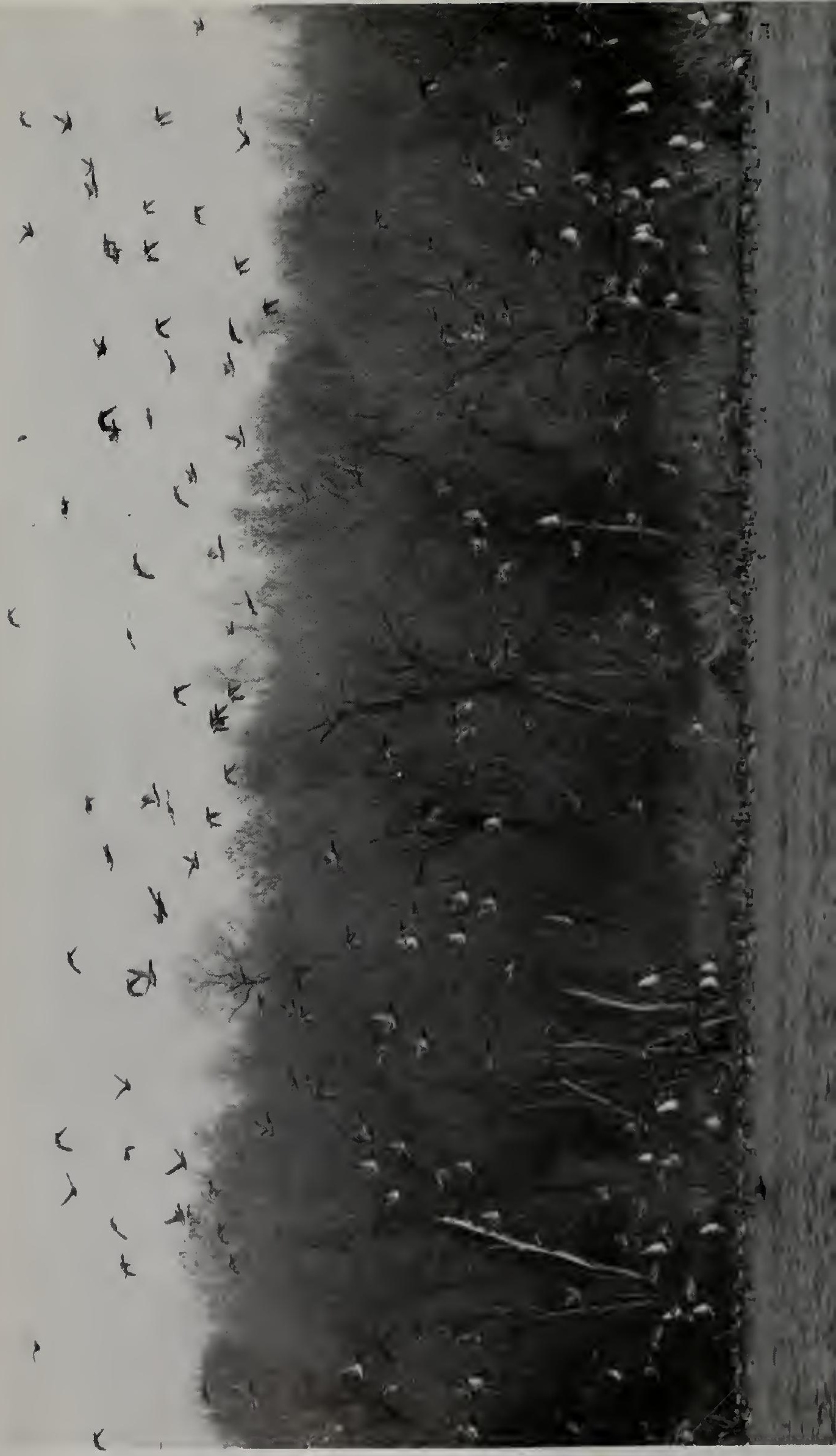




\title{
Waterfowl Populations and the Changing Environment of the Illinois River Valley
}

\author{
Frank C. Bellrose, Fred L. Paveglio, Jr., and Donald W. Steffeck
}

THE VALUE OF THE ILLINOIS RIVER valley for waterfowl lies in its bottomland lakes that flank the relatively narrow river channel between Spring Valley and Meredosia and between Pearl and Grafton. These lakes originated in the most recent glaciation (IVisconsinan), which profoundly altered the ancient Mississippi and Illinois rivers and created the mique Illinois Valley that we find today. Up to the 1930's, the Illinois River valley was one of the nation's outstanding waterfowl hunting areas. Since then it has been in a state of decline for a variety of reasons, some of which will be cliscussed here.

\section{GEOLOGICAL HISTORY}

Prior to the Wisconsinan glaciation, the Mississippi River flowed down the Illinois Valley below the Big Bend at Hennepin, Illinois, by means of a now buried channel between Bureau and northeastern Rock Island counties (WVillman \& Frye 1970). About 21,000 years ago, the most recent ice sheet, the Wisconsinan, moved westward past the Big Bend and diverted the Mississippi River westward to its present channel south of Muscatine, Iow'a (Willman 1973). As the Wisconsinan glaciation retreated, flood waters formed the Des Plaines and Kankakee rivers, which joined near Channahon to create the present Illinois River. From Channahon westward to the Big Bend at Hennepin, the Illinois carved a new valley. At the Big Bend, the flood waters of the g) lacial melt entered an ancient valley of the Mississippi River and followed this pathway sonthward to the present Mississippi River at Grafton.
Because the ancient Mississippi Valley through central Illinois had been broidlened and dcepened by repeated pre-IVisconsinan glacial melts, the IIlinois River entered a much deeper valley below Hennepin than was warrantcal by its volume of water. The valley has also been considerably filled with sediment carried by the glacial meltwater. This origin resulted in a river with an numsually low rate of fall: $0.03 \mathrm{~m}$ per $\mathrm{km}$ ( $0.17 \mathrm{ft}$ per mile) between Hennepin and Pekin, and 0.02 $m$ per $\mathrm{km}$ (0.13 ft per mile) from Pekin to Meredosia, Forbes \& Richardson (1920) reported that at ordinary levels the flow varied from 2.01 to 4.02 km (1.25-2.50 miles) per hour. Since 1938, navigation clams have further retarded the river velocity to about 1.0 km (0.6 mile) per hour (Starrett 197l). The gentle slope of the river below the Big Bencl has resulted, during postglacial times, in the valley's aggrading rather than croding, as do most river valleys.

The Illinois River's low volume of llow for its channel capacity and its low rate of fall combined to form the unique bottomland lakes associated with the Illinois Valley. Under overflow conditions, the faster-moving waters of the channel meet the slowermoving backwaters with the result that sediment is deposited more rapidly along this shear. Through eons of lime natural levees rosc, like barrier islands, to separale most of the channel waters from the adjacent bottomland waters. Thus evolved bottomland lakes, or backwater lakes, as the engincers term them (Fig. 1).

The very creation of bottomland lakes also set the stage for their exinction. The seclimentation that sep- 


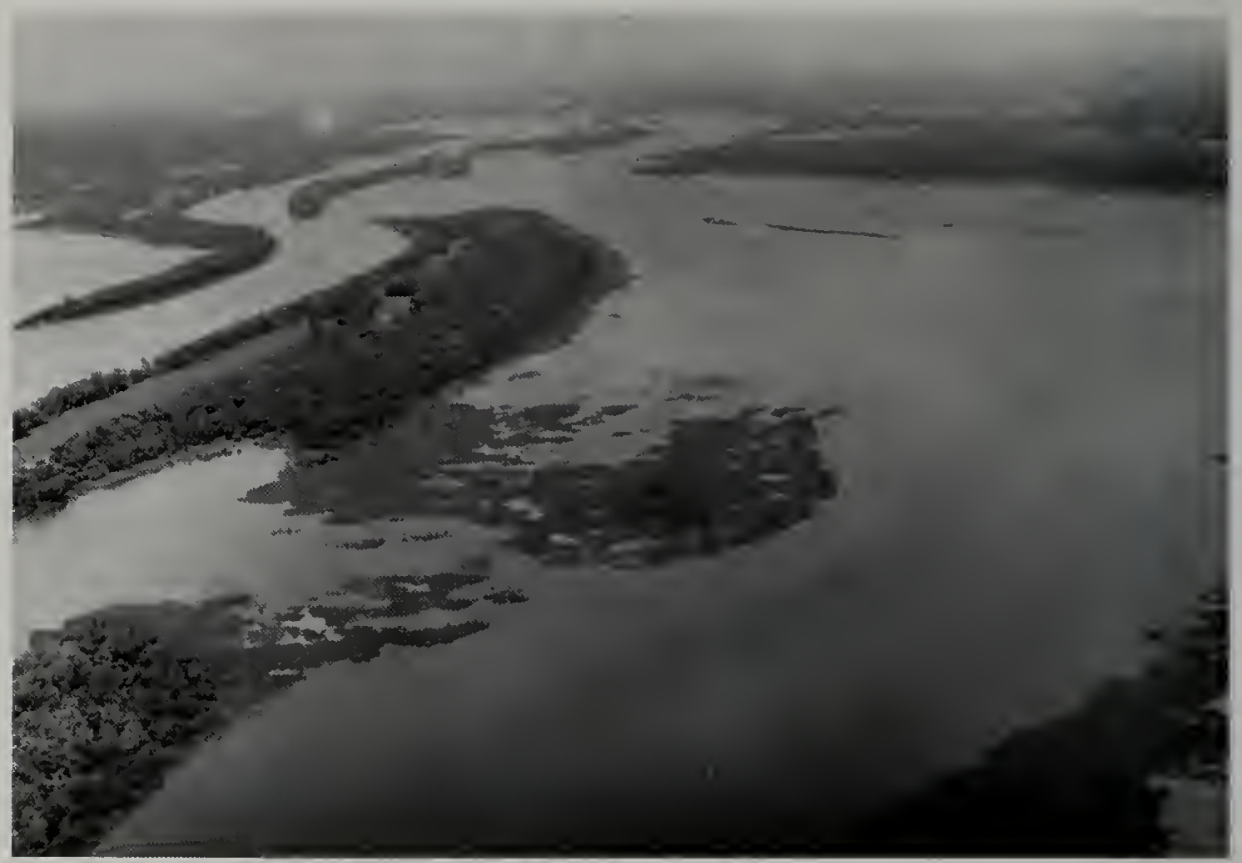

Fig. 1.- Illinois River north of Chillicothe, illustrating the natural banks that formed bortomland lakes in the Illinois Valley. The channel is shown meandering between Babbs Slough, Sawyer Slough, Big Meadow Lake, Wightman Lake, and Sparland Lake.

arated the lakes from the river channel is now rapidly engulfing them. Under pristine conditions, this extinction of individual bottomland lakes would probably have taken hundreds of years, and while one generation of lakes was being filled with sediment, another generation would have been formed by the growtl of new natural levees. Man, throngh intensive use of the land, has greatly accelcrated the process.

The lllinois Valley is especially subject to seclimentation because its tributary streams fall many times faster than does the main stream. For examp.e, the s!ope of the Spoon River, an important tributary, varies from 0.19 to $0.57 \mathrm{~m}$ per $\mathrm{km}$ ( $1-3 \mathrm{ft}$ per mile) (Evans \&. Schnepper 1977). Consequently. the rivers and creeks feeding the lltinois River transport enormons quantities of finely suspended soils to its waters. Since it flows more slowly, the Illinois in turn cleposits a sizeable proportion of this load in its network of botomland lakes during floods. At lower water stiges the river waters ming'c very little with the backwater lakes. Only Peoria Lake, through which the river llows, is continuously exposed to transported material.

\section{HISTORICAL CHANGES}

For 150 years following Pere Marsquette's and Louis Joliet's ascent of the Illinois River in 1673, its valley was populated largely by Indiaus and a few white tralers and trappers. In 1823 screral white families lived at the present site of Peoria, and Chicago was known as a military and mading post (Barrows 1910). However, the establishment of steambonting in 1823 brought an influx of immigrants, so that by 18.10 much of the Illinois Valley contained 6-18 people per square mile.

After 1840 the population of the 
valley grew apace. By 1900 there were 3.3 million people in the Illinois basin, 95 percent of which lies within the state of lllinois. The basin embraces slightly over half the area of the state.

To facilitate transportation, a canal was constructed in 1848 from Lake Michigan at Chicago to the Illinois River at $\mathrm{La}$ Salle. In addition, three low navigation dams and locks were constructed on the Illinois River, at Henry in 1871, at Copperas Creek near Banner in 1877, and at La Grange in 1889. These changes appear to have had little effect upon the natural biota of the Illinois Valley; its lakes were still nearly pristine.

Detailed maps of the Illinois Valley made by J. W. Woermann, Corps of Engineers, U.S. Army, from 1902 to 1904 indicate that slightly over onethird of the meadows and wooded bottomlands had been cleared and placed in some form of cultivation.

During the late 1890 's, the waters of the lllinois River still ran comparatively clear. Kofoicl (1903:151) described a boat trip across a series of bottomland lakes above Havana during high water in late May. Despite the high stage, waters were surprisingly clear: aquatic and marsh plants were beginning to appear in abundance, with coontail still "at some depth below the surface." In the waters of Thompson Lake (one of the largest lakes in the valley). Kofoid could see schools of young fry feeding upon plankton. Its waters were described as "somewhat turbicl but more from plankton than silt." The river channel was more turbid from silt and plankton than were the adjacent lakes.

Later in the summer, Kofoid (1903: 155) revisited the same lakes during low water. He found "the backwaters liave been recluced to the lakes, sloughs, and marshes which abound everywhere in the bottomlands." Most of the lakes were choked with aquatic plants or rushes. His descriptions of bottom soils suggest that they were composed more of decayed plant material than of silt.

\section{CHANGES DURING THE PRESENT CENTURY}

From 1900 to the present, the natural habitats of the Illinois Valley have experienced a sequence of overlapping catastrophic events. Had the Illinois River and its backwater lakes been a fragile ecosystem, they would have passed into oblivion long ago. With varying degrees of success, the aquatic communities of the Illinois Valley have withstood the ravages of man.

The first pronounced change occurred in 1900 with the completion of the Chicago Sanitary and Ship Canal, which diverted water from Lake Michigan and sewage effluent from Chicago to the lllinois River. The diversion ranged from 82.1 cubic meters per second (cms) (2,900 cubic feet per second-cfs) in 1900 to $283.4 \mathrm{cms}(10,010$ cfs) in 1928; from 1900 to 1938, it averagerl $204.5 \mathrm{cms}(7,222 \mathrm{cfs})$. A U.S. Supreme Court lecree limited cliversion to $42.5 \mathrm{cms}(\mathrm{l}, 500 \mathrm{cfs})$ after 1938 , but a second decree in 1961 increased the rate to $90.6 \mathrm{cms}(3,200 \mathrm{cfs})$.

Yearly water profiles at Peoria, 1868-1975, show that low-water levels climbed from $131.7 \mathrm{~m}(432 \mathrm{ft})$ mean sea level (msl) in 1899 to $132.1 \mathrm{~m}$ $(433.5 \mathrm{ft})$ in 1900 and $133.2 \mathrm{~m}(436.9$ $\mathrm{ft}$ ) in 1902. Until the Peoria lock and clam became operational in 1938 , low-water levels averaged about 133.5 in $(138.0 \mathrm{ft}) \mathrm{msl}$. The diversion of water into the Illinois River appears to have increased low-water levels at Peoria betwcen 1.5 and $1.8 \mathrm{~m}$ (5 and $6 \mathrm{ft}$ ). Forbes \& Richarclson (1919:140141) concluded that miclsummer levels at Havana rose an average of $1.1 \mathrm{~m}$ (3.6 $\mathrm{ft}$ ) above prediversion averages.

The diversion caused the flooding of thousands of hectares of bottomland 
forest during the growing season, killing the trees and enlarging the backwater lakes. Pin oaks and pecans, which had grown extensively in the valley below Peoria, were especially vulnerable to higher water. Their loss greatly reduced the mast food supply for mallards and wood ducks.

Overall, though, waterfowl benefited from the diversion of Lake Michigan water as the surface areas of lakes, sloughs, and marshes doubled. Prior to diversion, about 21,850 ha $(54,000$ acres) were in bottomland water areas, exclusive of the river channel. The diversion of Lake Michigan water expanded bottomland lakes and marshes to slightly over 48,560 lia $(120,000$ acres) in the 161,878-ha (400,000-acre) floodplain.

This expanded water area did not persist long but shrank due to man's next alteration of the Illinois River valley. Levee and drainage clistricts, largely initiated between 1903 and 1920 , placed 82,962 ha $(205,000$ acres) of bottomland behind levees (Mulvihill \& Cornish 1929). Natura] lakes and marshes within the leveed tracts were drained. The land in three drainage districts-Partridge, Chautauqua, and Big Prairie, aggregating 3,238 ha $(8,000$ acres)-was not farmed successfully and reverted to a seminatural state (Fig. 2). Ironically, this drainage district loss increased the lake and marsh surlace area to about 28,329 ha $(70,000$ acres), more than the precliversion 21,854 ha $(54,000$ acres). Irretrievably lost to waterfowl were the pin oak and pecan groves that had provided important food resources during floods.

At the same time that llinois Valley lakes were being altered by the creation of levees and drainage districts, the aquatic biotil was being threatened by yet another serious menace-that of urban wastes discharged into the Hhinois River. Although a small amount of polfution had occurred before 1900, the opening of the Chicago Sanitary and Ship Canal in 1900 created a prob-
Jem of catastrophic proportions for the river and its backwater lakes above Peoria (Mills et al. 1966). At first only the extreme upper reaches (abov' Marseilles) were affected. However, the zone of pollution steadily moved clownstream until by 1922 the upper Illinois was essentially a dead river, devoid of important aquatic life as far south as Chillicothe (Mills et al. 1966).

Extensive beds of pondweeds, wild celery, and coontail, present in Peoria Lake between 1910 and 1914, had largely disappeared by 1920 (Richardson 1921). In 1921, Peoria Lake contained slight growths of pondweeds and algae, so little as to be overlooked by the casual observer (Purdy 1930).

A decline in urban and industrial pollution began with the operation of treatment plants by the Chicago Sanitary District in 1922. Pollution control was aicled by the navigation dams that became operational in the upper river in 1933. These dams reduced the rate of flow, thereby resulting in bacterial decomposition of waste products within a shorter distance downstream. A gradual reduction in the urban pollution of the Illinois River has continued to the present time (Richard Sparks, lllinois Nitural History Survey, personal communication).

The 9-foot $(2.7-\mathrm{m})$ waterway for navigation became operational above the Starved Rock lock and dam in 1933 and below that point in 1938. The waterway below Starved Rock was created by dredging the chamnel deeper and raising the water levels by clams at Peoria, below Beardstown, and on the Mississippi River at Alon.

Even as the urban and inclustrial pollution abated, the Illinois River and its lakes were subjected to yet another degratation, that of pollution from sedimentation. The permanent and inviclious nature of silt pollution makes it more harmful than urban pollution: although not as apparent, it is accumulative.

This report examines the role of 


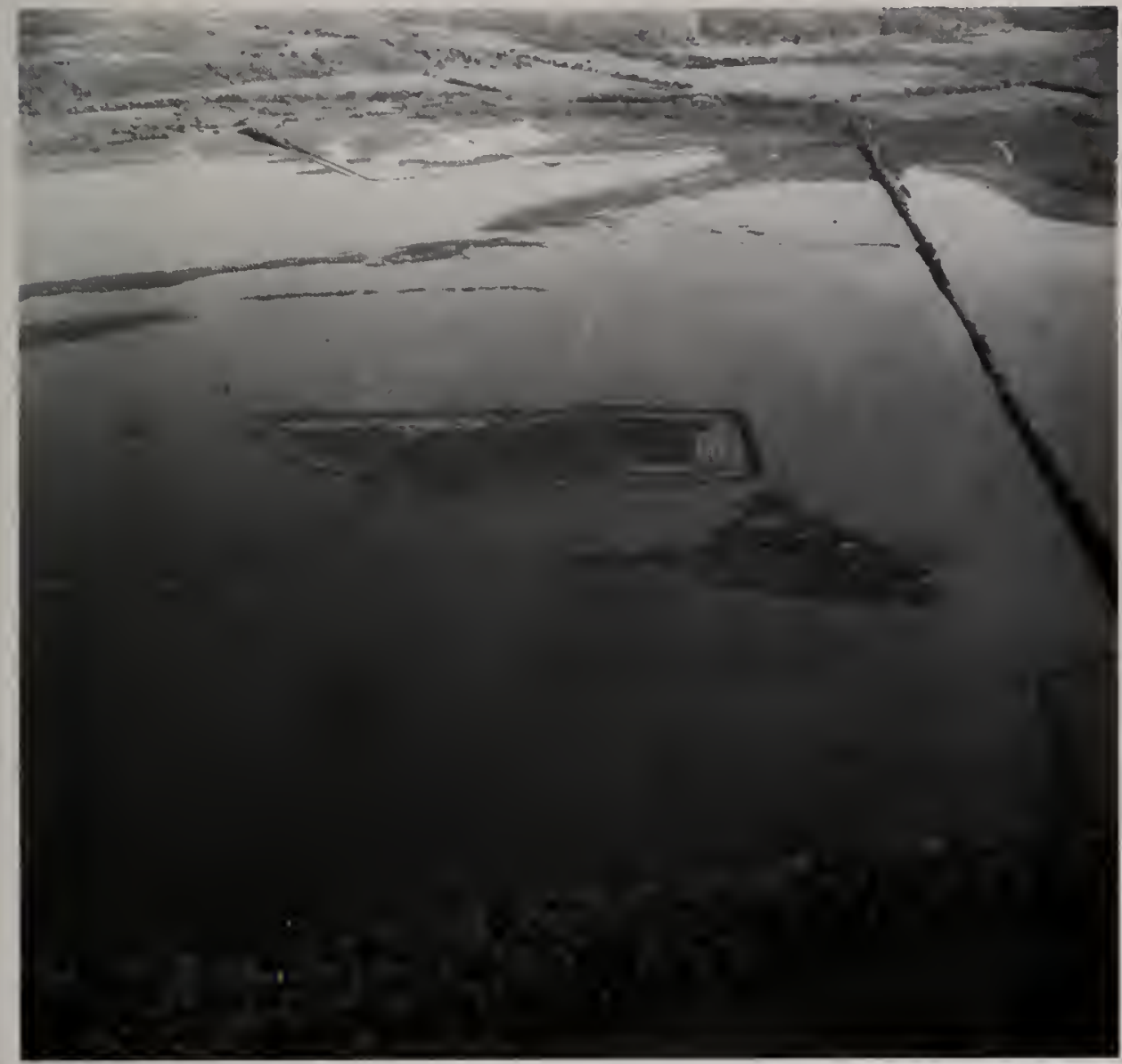

Fig. 2.-A portion of the abandoned Partridge Levee District located at the northern end of Upper Peoria Lake across from Chillicothe, showing a leveed area (center) dewatered for moist-soil plant development.

sedimentation in the Illinois Valley: its effects on alpuatic, marsh, and moistsoil plants and its effects upon watterlowl alsumelance.

\section{ACKNOWLEDGMENTS}

We are inclebted to these persons and organizations for their contributions to this pajer.

Part of the material presented, particularly that on sedimentation, was derived from studies funanced by the bepartment of the Arnsy, Chicago District, Corps of Engineers, Project DACIV 23-76-6-0066 under project leader Exlward Hanses.

Dr. David L. Gross, Illinois State
Geological Survey, reviewerl the section on Geological llistory and made pertinemt suggestions. Dr. Vernon Wright, formerly with the Illinois Department of Conservation, provided guidance in the statistical analyses.

Forrest Loomis, now with the Illinois Department of Conservation, conducted field studies and made vegetation maps of hotomland lakes, $1955-$ 1957.

1)rs. Leigh Frealerickson of the University of Missouri and David Tratuger of the U.S. Fish and Wildlife Service reviewed the pilper and offered suggestions for improvement.

$\Lambda$ number of Illinois Natural His- 
tory Survey staff members contributed to this paper: Lloyd LeMere, Technical Illustrator, drew the graphs. Dr. Glen C. Sanderson, Head, Section of Wildlife Research, Mrs. Eva Steger, and Harold Henderson did preliminary editing. Final editing and preparation of the paper for publication was done by Robert M. Zewadski, Technical Editor.

\section{METHODS}

Three diverse aspects of Illinois River habitat were measured for this report: (1) the rate of sedimentation in various bottomland lakes, (2) the abundance and distribution of aquatic, marsh, and moist-soil plants, and (3) the abundance of waterfowl as related to the availability of aquatic and moistsoil vegetation and mollusks (Fig. 3).

\section{SEDIMENTATION}

Reports on the sedimentation of three bottomland lakes have been issued by personnel of the Illinois State Water Survey (M. T. Lee. 1976. Sediment deposition of Lake Chautauqua, Havana, Illinois. Unpublished Xeroxed report. M. T. Lee and J. B. Stall. 1976. Sediment deposition in Lake DePue, DePue, Illinois and its implications for future lake management. Unpublished Xeroxed report. M. T. Lee, J. B. Stall, and T. A. Butts. 1976. The 1975 sediment survey of Lake Meredosia, Meredosia, Illinois. Unpublished Xeroxed report). In addition, we made sedimentation studies on these lakes: Senachwine, Sawmili, Billsbach, Sparland, Wightman, Babbs Slough, Upper Peoria, Rice, Clıautauqua, Anderson, and Meredosia.

Comparisons between present-day water depths and earlier readings were possible because of soundings conducted in the Illinois Valley in 19021904 by J. W. Woermann, Assistant Engineer, Corps of Engineers, U.S. Army. Differences in water depths of lakes, slouglis, and marshes were used to cletermine the amount of sedimentation that has occurred during an interval of $73-75$ years.

Fortunately, at three lakes sedimentation could be separated into two periods during this time span. At Lake Chautauqua, Stall \& Melsted (195I) studied sedimentation between 1926 and 1950, and Lee (1976 unpublished) studied it during 1950-1976. The Peoria Project Office, U.S. Army Corps of Engineers, took soundings of Peoria Lake in 1965 . These studies enabled us to calculate the sedimentation at Peoria Lake for two periods: 1903-1965 and 1966-1976. Soundings of Meredosia Bay were taken in 1956 by the State Division of Water Resources and by us in February 1978. Sedimentation rates were calculated for the periods 1903-1956 and 1957-1978.

\section{WATER DEPTH}

In our 1976 and 1977 soundings, 310 transects were established across each lake. Depths along the transects were taken at approximate intervals of 77.7 m (85 yards) except in Upper Peoria Lake, where the interval was 228.6 $\mathrm{m}$ (250 yards). The depth of water was related to the river stage (i.e., to the nearest gauge reading adjusted for the slope of the river). From these data the mean sea level (msl) elevation of each lake bottom was derived. The elevations of lake bottoms on the 1902-1904 J. W. Woermann maps were based upon the Memplis Datum (MD). The Memphis Datum was an arbitrary elevation at Memphis, Tenn., used as a reference point in measuring other elevations. The Memphis Datum was converted to usl (1929 general adjustment) by subtracting a correction factor varying from 2.26 to $2.27 \mathrm{~m}$ (7.43$7.45 \mathrm{ft}$ ) depending upon the location of the bencl marks.

The areas of bottomland lakes in the Illinois River valley were determined by using a planimeter to measure the basin areas as delineated by the 
wooded-vegetation line on the U.S. series of the Woermann 1902-1904 Army Corps of Engineers 1933 revised maps.

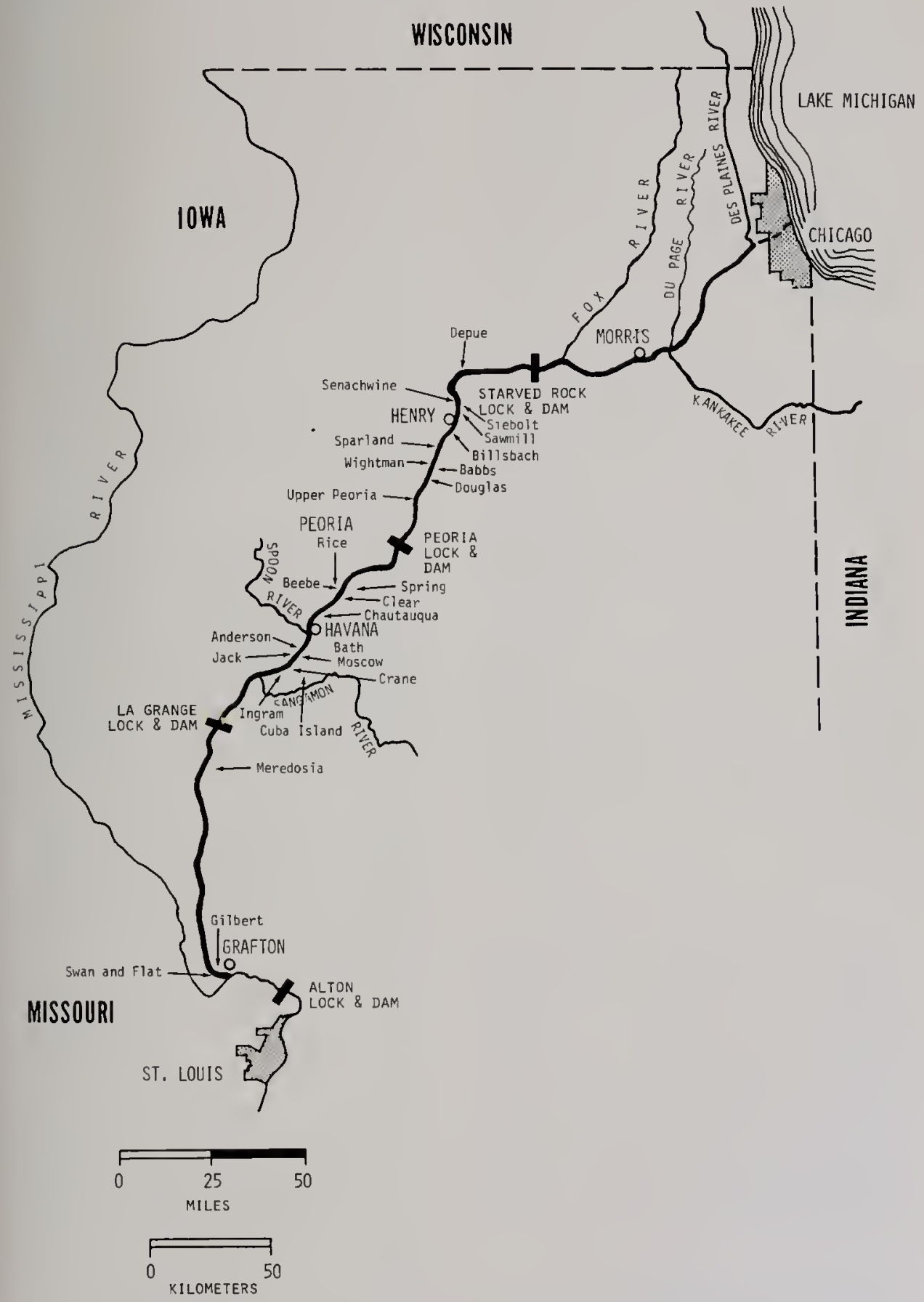

Fig. 3.- Map of the Illinois River valley, showing many of the bottomland lakes included in this study of wetland plants, sedimentation, and waterfowl abundance. 


\section{WETLAND VEGETATION}

The areas of waterfowl food plants (aquatic, marsh, and moist-soil species) were taken from maps drawn by Frank Bellrose, 1938-1953, and by Forrest Loomis, 1955-1957. Waterfowl food plant beds were plotted by rough triangulation on the base maps provided by the U.S. Army Corps of Engineers 1933 map scries scalcd 1:12000 (Bellrose $19+1$ ). Later vegetation maps prepared for 1959 and 1976 were based upon aerial photographs interpreted by Bellrose.

Mapped plant beds were measured by planimeter to determine their sizes in acres. To weight areas devoid of vegetation, acreages of plants were divided by the acreage of the bottomland lake basin mapped each year to obtain the percentage of the area covered by waterfowl food plants. To compare annual changes in vegetation composition, the abundance of each plant species was determined and related to the entire lake basin. The measured acreage of each lake basin varied slightly from year to year, depending upon the specific area mapped. Recent information on the status of wetland p!ants on Gilbert and Swan lakes was derived from the files of the Mark Twain National Wildlife Refuge, Quincy, Hiinois.

\section{WATERFOWL POPULATIONS}

Censuses of waterfowl were taken in the Illinois Valley 1938-1970 by Frank Bellrose and 1971-1976 by Robert Crompton. However, the data are better since 1949, when a light aircraft made it possible to cover the valley completely I day cach weck from I October to 1 December. WVaterfowl numbers obtained from the weekly censuses were multiplied by seven to obtain the duck-day's of use for cacli fall.

\section{MOIST-SOIL WATER-LEVEL AND WATER-STABILITY INDICES}

To evaluate the relationship of river tevels to the abundance of wetland plants, a growth-period index was established for wetland plants and a water-level index was established by computing weekly averages from daily water-level gauge readings.

IVe converted National Oceanic and Atmospheric Administration Environmental Data and lnformation Service daily gauge readings to weekly averages. Becautuse of the sluggish nature of the river, weekly averiges adequatel! rellect its rise and fall.

The growth-period index was based upon the assumption that the earliest low-water stage that could benefit wetland plants is 1218 June, the latest, 14-20 August. After that date too few days remain before the average date of the first heavy frost for plants to produce a meaningful amount of seeds. The weeks of this 10-week period were ranked in descending order with the week of 12-18 June ranked 10 and that of 14-20 August ranked 1 .

Weekly average gange readings were assigned water-level index values that increased as the water level receded from the wooled shoreline, exposing an area of lake basin for the development of moist-soil plants. The lower the river level, the larger the assigned water-level index. Water levels at or above the wooded shoreline were designated as 0 . The upper limits of the wooded shoreline elevation on the Henry gauge is $135.0 \mathrm{~m}(4.13 \mathrm{ft}$ ) $11 \mathrm{sl}$ and on the Havana gange it is $133.2 \mathrm{~m}$ $(437 \mathrm{ft}) \mathrm{msl}$.

Each water-level index was multip.ied by the growth-period index. The resulting products were squared and then totaled for the 10-week period. The result is the Moist-Soil WaterLevel Index. The products were squared because the exposure of mud flats is exponentially rather than linearly related to declining water levels. With the exception of Peoria Lake. lake basins of the Hllinois River are shallow and platter shaped. Therefore. as water levels declinc, an ever larger proportion of the lake basin is cxposed as mud flats. 
The Moist-Soil Water-Level Index was first compared with the moist-soil vegetation acreage over a 22-year period, 1938-1959, by linear regression. Secondly, the Moist-Soil Water-Level Index was compared by linear regression with the fall duck-dlay use of Illinois Valley lakes, 1949-1976.

On the other hand, to evaluate the effect of water levels on aquatic and marsh plants, a Water-Stability Inclex was calculated. A level $0.6 \mathrm{~m}(2 \mathrm{ft})$ above the prevailing low-water stage was julged to be optimum for aquatic plants. The absolute values of deviations from this level, based upon weekly gauge averages, were totaled for the growing season. The larger the Water-Stability Index, the more adverse were conditions for aquatic and marsh plant development.

\section{WATERFOWL FOOD RESOURCES}

A preliminary report on the waterfowl food resources of the Illinois Valley and the factors affecting them during the 1938-1940 period was made by Bellrose (1941). We present liere those findings and others made since then.

From the earlier study (Bellrose 1941) it is apparent that the four most important factors affecting the abundance of duck food plants in bottomland lakes of the Illinois River are (1) fluctuating water levels, (2) turbidity, (3) water depth, and (4) competition by other plants that provicle little or no duck food.

In the present study we sought to examine further the effects of each of these factors upon the vegetation of valley lakes, but we also recognize that all of the factors are interrelated. Turbiclity stems from sedimentation, which in turn alters water depth and may encourage the growth of some weed species at the expense of more beneficial plants. When the river rises, more sediment is deposited and turbidity increases.

Fluctuating water levels can affect waterfowl habitats in opposite ways. Uncontrolled fluctuations result in minimal development of aquatic, marsh, and moist-soil plants. However, controlled fluctuations can result in highly productive food resources if they occur within the optimum 120-day summer growing period.

Because the degree of control of water levels is so important to the waterfowl food plant resources of the Illinois Valley, we have separated bottomland lakes into four classes according to their association with the river ( $\mathrm{Ta}$ ble 1):

Class I, areas whose water levels are completely controlled by changing river levels

Class 11, areas that are separated from the river at low water stages

Class 11I, areas that remain separated from the river up to flood stage, when the river begins to overtop its natural banks

Class IV, areas that are above the river's designated flood stage (bank full)

Class 111 areas are further categorized according to management practices: Class IIIA, areas where water levels are stabilized at an optinum level below llood stage for aquatic and marsh plants, and Class I11B, areas where the lake is dewatered for optimum production of moist-soil plants.

Under severe flooding all areas but Spring Lake, near Pekin, come under the influence of the river. The entire 520-ha (1,285-acre) basin of Spring Lake is separated from the river by high levees; water control structures added in 1977 will make it possible in the future to manipulate water levels on 26] ha (645 acres) of Spring Lake.

Other wetlands are separated to varying degrees from the influence of the river, either because of the elevation and formation of their basins, or because low levees isolate the areas. Low levees have been built by private duck clubs, the Illinois Department of Conservation, and the U.S. Fish and Wildlife Service to provide some low-level water control on wetlands under their 
respective ownerships. Most of the the river. Pumps are frequently emstructures isolating the river waters are ployed to assist in the dewatering and no higher than the natural banks of reflooding of impounded wetlands.

Table 1.- Surface areas of Illinois River valley lakes in relation to the degree of separation from the influence of the river, 1977." Figures are in hectares $(2.471$ acres/hectare).

\begin{tabular}{|c|c|c|c|c|c|}
\hline Bottomland Lakes & $\begin{array}{l}\text { Total } \\
\text { Area }\end{array}$ & $\begin{array}{c}\text { Class l } \\
\text { (river } \\
\text { contiol) }\end{array}$ & $\begin{array}{c}\text { Class II } \\
\text { (slight } \\
\text { control) }\end{array}$ & $\begin{array}{c}\text { Class III } \\
\text { (moderatc } \\
\text { control) }\end{array}$ & $\begin{array}{c}\text { Class IV } \\
\text { (maximum } \\
\text { control) }\end{array}$ \\
\hline \multicolumn{6}{|c|}{ Peoria Pool } \\
\hline Banner Hill-Utica Pond & 11.0 & $\ldots$ & $\ldots$ & 11.0 & ... \\
\hline Split Rock Lakes & 72.8 & $\ldots$ & $\ldots$ & 72.8 & $\ldots$ \\
\hline Huse Lake & 19.7 & 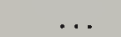 & 19.7 & $\ldots$ & $\ldots$ \\
\hline Huse Slough and Pond & 31.8 & 31.8 & $\ldots$ & ... & $\cdots$ \\
\hline Treetop \& Sadnick's lakes & 23.1 & .. & 23.1 & $\ldots$ & $\ldots$ \\
\hline Mud Lake area & 33.8 & $\ldots$ & 33.8 & $\ldots$ & $\ldots$ \\
\hline River Mile 216-217 & 26.3 & 26.3 & & $\ldots$ & $\ldots$ \\
\hline Turner Lake & 140.9 & $\ldots$ & 140.9 & $\ldots$ & $\ldots$ \\
\hline Depue Lake \& Hicks Slough & 248.1 & 242.0 & & 6.1 & $\ldots$ \\
\hline Lyons Lake & 13.7 & & 13.7 & ... & ... \\
\hline Spring Lake & 238.2 & 125.7 & $\ldots$ & 112.5 & $\ldots$ \\
\hline Coleman Lake & 52.6 & $\ldots$ & $\ldots$ & 52.6 & $\ldots$ \\
\hline North Hennepin area & 38.4 & $\ldots$ & $\ldots$ & 38.4 & ... \\
\hline Goose Pond & 697.2 & 575.8 & $\ldots$ & 121.4 & $\ldots$ \\
\hline Senachwine Lake \& Hunter's Slough & $1,865.2$ & $1,708.2$ & 124.6 & 32.4 & $\ldots$ \\
\hline Siebolt Lake (French Slough) & 178.0 & $\ldots$ & 80.9 & 97.1 & $\ldots$ \\
\hline Big Spring area & 20.2 & $\ldots$ & $\ldots$ & 20.2 & $\ldots$ \\
\hline Sawmill Lake & 309.3 & 309.3 & $\ldots$ & $\ldots$ & $\ldots$ \\
\hline Mud Lake & 26.4 & 26.4 & $\ldots$ & $\ldots$ & $\ldots$ \\
\hline Town Lake area \& Whitney Lake & 37.6 & 7.2 & $\ldots$ & 30.4 & $\ldots$ \\
\hline Merdian Slough & 19.3 & 19.3 & $\ldots$ & $\ldots$ & $\ldots$ \\
\hline Billsbach Lake & 454.1 & 429.4 & $\ldots$ & 24.7 & $\ldots$ \\
\hline Weis Lake & 132.9 & 132.9 & $\ldots$ & $\ldots$ & $\ldots$ \\
\hline Sparland Lake (Goose Lake) & 451.9 & 451.9 & $\ldots$ & $\ldots$ & $\ldots$ \\
\hline Fisher's Slough & 147.0 & 147.0 & $\ldots$ & $\ldots$ & $\ldots$ \\
\hline Sawyer Slongh & 200.0 & 200.0 & $\ldots$ & $\ldots$ & $\ldots$ \\
\hline Wightman Lake & 258.2 & 258.2 & $\ldots$ & ... & $\ldots$ \\
\hline Babbs Slough & 777.2 & 777.2 & $\ldots$ & $\ldots$ & $\ldots$ \\
\hline Big Meadow Lake & 274.6 & 274.6 & $\ldots$ & $\ldots$ & $\ldots$ \\
\hline Chillicothe Island & 8.1 & $\ldots$ & $\ldots$ & 8.1 & $\ldots$ \\
\hline Douglas Lake-Ricc Pond & 912.6 & 323.7 & $\ldots$ & 588.9 & $\ldots$ \\
\hline Goose Lake & 832.4 & 809.3 & $\ldots$ & 23.1 & $\ldots$ \\
\hline Upper Peoria Lake & 3.738 .9 & $3,725 . \mathrm{J}$ & $\ldots$ & 13.8 & $\cdots$ \\
\hline Lower Pcoria Lake & $1,044.7$ & $1,044.7$ & $\ldots$ & $\ldots$ & $\ldots$ \\
\hline Beesaw Lake & 77.0 & 77.0 & ... & ... & ... \\
\hline \multicolumn{6}{|c|}{ La Grange Pool } \\
\hline Long Lake \& Mud Lake arca & 197.8 & 197.8 & & $\ldots$ & $\ldots$ \\
\hline Pekin Lake area & 290.2 & & 290.2 & $\ldots$ & ... \\
\hline Boot Jack Lake area & 105.8 & 105.8 & $\ldots$ & $\ldots$ & $\ldots$ \\
\hline Kingston Lake arca & 30.9 & 30.9 & $\ldots$ & $\ldots$ & $\ldots$ \\
\hline Spring Lake & 520.0 & $\ldots$ & $\ldots$ & $\ldots$ & 520.0 \\
\hline Pond Lily Lake & 28.3 & $\ldots$ & $\ldots$ & 28.3 & .. \\
\hline Rice \& Miserable lakes & 661.2 & $\ldots$ & $\ldots$ & 539.8 & 121.4 \\
\hline Becbe Lake (Big Lake) & 583.5 & ... & 547.1 & 36.4 & $\cdots$ \\
\hline Goose Lake & 333.1 & $\ldots$ & 214.1 & 119.0 & $\ldots$ \\
\hline Clear Lake & 936.6 & $\ldots$ & 936.6 & $\ldots$ & ... \\
\hline Chantauqua Lake & $1,560.9$ & ... & $1,560.9$ & ... & $\ldots$ \\
\hline Liverpool Lake & 74.7 & 74.7 & $\ldots$ & $\ldots$ & $\ldots$ \\
\hline Quiver Lake & 112.2 & 112.2 & ... & ... & ... \\
\hline Horseshoe Lake & 9.5 & 9.5 & $\ldots$ & $\ldots$ & $\ldots$ \\
\hline Matanzas Bay area & 197.1 & $\ldots$ & 175.2 & 21.9 & $\ldots$ \\
\hline Bath Lake & 59.6 & 10.2 & $\ldots$ & 49.4 & $\ldots$ \\
\hline
\end{tabular}


The arrangement of levees often sep- category. Through the years 1938arates wetlands into more than one 1977 , the percentage of the lake basins

\begin{tabular}{|c|c|c|c|c|c|}
\hline Bottomland Lakes & $\begin{array}{l}\text { Total } \\
\text { Area }\end{array}$ & $\begin{array}{c}\text { Class l } \\
\text { (river } \\
\text { control) } \\
\end{array}$ & $\begin{array}{c}\text { Class II } \\
\text { (slight } \\
\text { control) } \\
\end{array}$ & $\begin{array}{l}\text { Class III } \\
\text { (moderate } \\
\text { control) }\end{array}$ & $\begin{array}{c}\text { Class IV } \\
\text { (maximum } \\
\text { control) }\end{array}$ \\
\hline Mloscow Lake & 107.8 & 81.1 & ... & 26.7 & ... \\
\hline \multicolumn{6}{|l|}{ Grand Island: Grass, Goose, \& } \\
\hline $\begin{array}{l}\text { Jack lakes } \\
\text { Anderson Lake }\end{array}$ & $\begin{array}{l}71.4 \\
635.4\end{array}$ & $\begin{array}{r}72.0 \\
\ldots\end{array}$ & $\begin{array}{r}639.4 \\
\ldots\end{array}$ & 635.4 & $\cdots$ \\
\hline $\begin{array}{l}\text { Anderson Lake } \\
\text { Patterson \& Matthews bays }\end{array}$ & 73.3 & 43.8 & $\cdots$ & 29.5 & \\
\hline $\begin{array}{l}\text { Patterson \& Matthews bays } \\
\text { Snicarte Island area }\end{array}$ & 45.8 & & $\ldots$ & 45.8 & $\cdots$ \\
\hline Chain \& Slim Jakes & 284.4 & 284.4 & $\ldots$ & $\ldots$ & $\ldots$ \\
\hline Stewart Lake & 566.7 & 323.9 & $\ldots$ & 242.8 & $\ldots$ \\
\hline Ingram Lake & 440.6 & $\ldots$ & $\ldots$ & 360.3 & 80.3 \\
\hline Crane \& Pin Oak lakes & 468.0 & $\cdots$ & 320.5 & 22.0 & 125.5 \\
\hline Rainbow Gun Club & 69.6 & $\ldots$ & $\cdots$ & 69.6 & ... \\
\hline Long Lake & 60.1 & $\cdots$ & $\cdots$ & 60.1 & $\ldots$ \\
\hline Hickory Island & 29.1 & 29.1 & $\cdots$ & $\cdots$ & ... \\
\hline Sanganois Conservation Area & 485.6 & .. & $\cdots$ & 485.6 & ... \\
\hline Cuba Island & 594.1 & $\cdots$ & ... & 594.1 & $\ldots$ \\
\hline Sangamon Bay & 114.5 & 114.5 & ... & & ... \\
\hline Treadway Lake & 275.4 & 259.2 & $\cdots$ & 16.2 & ... \\
\hline Sugar Creck Lake & 74.6 & 74.6 & $\ldots$ & $\cdots$ & $\cdots$ \\
\hline Coleman's Lake & 49.6 & $\ldots$ & 49.6 & $\cdots$ & ... \\
\hline Big \& Little lakes & 63.0 & 63.0 & $\ldots$ & $\ldots$ & ... \\
\hline Wood Slough & 186.4 & 180.3 & $\cdots$ & 6.1 & $\ldots$ \\
\hline Muscooten Bay \& Hager Slough & 311.8 & 311.8 & $\ldots$ & $\ldots$ & ... \\
\hline York Lake & 159.0 & 159.0 & ... & ... & $\cdots$ \\
\hline \multicolumn{6}{|l|}{ South Bearclstown Lake, } \\
\hline Big Prairie area & 275.0 & $\ldots$ & 275.0 & $\ldots$ & ... \\
\hline \multicolumn{6}{|c|}{ Alton Pool } \\
\hline Meredosia Lake area & 655.1 & ... & 588.1 & 67.0 & $\ldots$ \\
\hline Atkinson Lake & 116.6 & 116.6 & $\ldots$ & $\ldots$ & ... \\
\hline Barlow Lake & 20.0 & 20.0 & $\cdots$ & $\cdots$ & $\cdots$ \\
\hline Smith Lake & 71.1 & $\ldots$ & 71.1 & $\ldots$ & ... \\
\hline Allens Lake & 80.9 & 80.9 & $\cdots$ & $\cdots$ & $\cdots$ \\
\hline McCoe Lake & 14.6 & 14.6 & $\cdots$ & $\cdots$ & $\cdots$ \\
\hline Jack Ellis Lake & 7.7 & 7.7 & $\ldots$ & $\ldots$ & ... \\
\hline Prairie Lake & 8.9 & 8.9 & $\ldots$ & $\ldots$ & $\cdots$ \\
\hline Michael Lake & 10.1 & ... & $\ldots$ & 10.1 & ... \\
\hline Hurricane Island & 16.2 & $\ldots$ & $\ldots$ & 16.2 & $\ldots$ \\
\hline Godar's Swamp & 36.4 & $\ldots$ & $\cdots$ & 36.4 & $\ldots$ \\
\hline Diamond Island & 105.2 & $\ldots$ & $\ldots$ & 105.2 & $\cdots$ \\
\hline llelmbold Slough & 27.9 & $\ldots$ & $\ldots$ & 27.9 & $\ldots$ \\
\hline The Glades area & 78.1 & ... & $\ldots$ & 78.1 & $\ldots$ \\
\hline Twclve Mile Island & 8.1 & .. & $\cdots$ & 8.1 & $\ldots$ \\
\hline Stump Lake area & 494.1 & $\ldots$ & $\ldots$ & 494.1 & $\ldots$ \\
\hline Gilbert Lake & 83.8 & $\ldots$ & $\cdots$ & 83.8 & $\ldots$ \\
\hline Swan Lake area & $1,143.2$ & $1,017.7$ & $\ldots$ & 125.5 & ... \\
\hline Calhoun National Wildlife Refuge & 78.5 & $\ldots$ & $\cdots$ & $\ldots$ & 78.5 \\
\hline Calhoun Point & 161.1 & 66.0 & $\cdots$ & 95.1 & $\cdots$ \\
\hline \multicolumn{6}{|c|}{ Totals } \\
\hline Peoria Pool & $13,413.2$ & $11,723.0$ & 436.7 & $1,253.5$ & 0.0 \\
\hline La Grange Pool & $11,881.7$ & $2,636.9$ & $5,008.6$ & $3,389.0$ & 847.2 \\
\hline Alton l'ool & $3,217.6$ & $1,332.4$ & 659.2 & $1,147.5$ & 78.5 \\
\hline Tolals & $28,512.5$ & $15,692.3$ & $6,104.5$ & $5,790.0$ & 925.7 \\
\hline Percentages & $\ldots$ & 55.04 & 21.41 & 20.31 & 3.25 \\
\hline
\end{tabular}

areas were obtained by measuring lake basins with a planimeter on U.S. Army Corps of Engineers (1933) map series of the Itlinois River valley. 
associated with the river has changed as some levees have been destroyed by floods and as others have been newly constructed. Table I shows the waters in the four categories of control as of the summer of 1977. However, for purposes of evaluating wetland vegetation in association with water levels, the degree of water level control at the time of the study is discussed. Local alterations in water level were made on certain lakes during this period, complicating their evaluation.

\section{RIVER LEVELS}

Three navigation dams, at Peoria, La Grange, and Alton, influence water levels, and thus bottomland lakes, in the Illinois River valley. These dams began operation late in 1938 and have influenced river levels and vegetation from the 1939 growing season to the present.

Although the Alton dam is on the Mississippi River $24.1 \mathrm{~km}$ (15 miles) below the mouth of the Illinois River, its navigational infuence extends 128.7 $\mathrm{km}$ (80 miles) up the Illinois to the La Crange lock and dam. Similarly, the La Grange mavigation pool extends $125.5 \mathrm{~km}$ (78 miles) to the Peoria lock and dam, and the Peoria navigation pool extends $117.5 \mathrm{~km}$ (73 miles) to the Starved Rock lock and dim near Utica. Other navigation dams-Marseilles, Dresden Island, Brandon Road, and Lockport-form additional naviga(ion pools upstream, but they are only of incidentil concern in this report.

Because of its great height, which resulted in raising the river level $8.1 \mathrm{~m}$ (27.7 ft), the Alton clam has had the most inlluence on the water levels of lakes upitream from the mouth of the Illinois River. Both Lil (irange and Peoria are low-level dams, $3.0 \mathrm{~m}$ (10 ft) and $3.4 \mathrm{~m}$ (1) lt), respectively, and have hat relatively minor effects upon river levels. Of course, as with all dams, their greatest control orer river levels is at the dim site, and their influence upstream declines according to their height and the rate of fall of their pools. River control progressively declines to the tailwaters of the next dam upstream, where water levels behave about as they did in preimpoundment days.

As far as we can ascertain, the Alton dam has litt'e influence over river levels above Pearl, the La Grange dam above Havana, and the Peoria dam above Henry. One reason that they appear to have had so little infuence on present-day water levels is that when they became operational in 1938 the diverted flow of water from Lake Micltigan into the Illinois River was reduced from $141.6 \mathrm{cms}(5.000 \mathrm{cfs})$ to $42.5 \mathrm{cms}$ $(1,500 \mathrm{cfs})$. In 1961, the lischarge was raised to $90.6 \mathrm{cms}(3.200 \mathrm{cfs})$. Both the Havana and Henry gauges are about midway in their respective navigation pools, and they thus provide the best recorl of changing water levels that inlluence wetland plants.

We consider the period 15 June-12 October to be the most lavorable season for the development of marsh, aquatic. and moist-soil plants. An earlier period would be still better lor aquatics, but the earlier the date, the less likely is low water, because of spring floods. The minimum period of dewatering (between 15 June and 12 October) within which moist-soil plants can produce mature seed (although not at top yields) is 70 days.

A review of river levels at Henry, 1938-1976, shows that during the perios 15 June-12 October seasonal means ranged from 1.2 to $2.3 \mathrm{~m}(3.8$ $7.5 \mathrm{ft}$ ) (Table 2). Downstream at Havina during the same period, seasonal means ranged more widely; from 1.8 to $3.6 \mathrm{ml}(5.9-11.9 \mathrm{ft})$ (Table 2). This areater fluctution results from large tributary streams aclding their sizcable discharges to the lllinois River between Peoria and llavana.

The weekly mean gauge records for 15 June-12 October were averiged for ath year, and standard deviations were computed. The lower the mean and its standard deviation, the more mud llats were exposed, and the longer 
Table 2.-Water level fluctuations (in meters) in the Illinois River at two stations between 15 June and 12 October, 1938-1976.

\begin{tabular}{|c|c|c|c|c|c|c|}
\hline \multirow[b]{2}{*}{ Year } & \multicolumn{3}{|c|}{ Henry Gauge } & \multicolumn{3}{|c|}{ Havana Gaugeb } \\
\hline & $\begin{array}{c}\text { Seasonal } \\
\text { Mean }\end{array}$ & SD & Range & $\begin{array}{c}\text { Seasonal } \\
\text { Mean }\end{array}$ & SD & Range \\
\hline 1938 & 1.57 & 0.71 & 2.25 & 3.23 & 0.70 & 2.04 \\
\hline 1939 & 1.25 & 0.12 & 0.55 & 2.19 & 0.62 & 1.68 \\
\hline 1940 & 1.17 & 0.04 & 0.15 & 1.83 & 0.24 & 0.97 \\
\hline 1941 & 1.32 & 0.41 & 1.74 & 2.18 & 0.72 & 2.83 \\
\hline 1942 & 1.27 & 0.14 & 0.64 & 2.46 & 0.46 & 1.43 \\
\hline 1943 & 1.49 & 0.55 & 2.13 & 2.67 & 1.14 & 3.99 \\
\hline 1944 & 1.31 & 0.05 & 0.18 & 2.08 & 0.43 & 1.61 \\
\hline 1945 & 1.44 & 0.21 & 0.76 & 2.74 & 0.87 & 2.83 \\
\hline 1946 & 1.40 & 0.40 & 1.37 & 2.40 & 1.00 & 2.93 \\
\hline 1947 & 1.50 & 0.61 & 2.29 & 2.65 & 1.39 & 4.08 \\
\hline 1948 & 1.27 & 0.15 & 0.67 & 2.17 & 0.48 & 1.65 \\
\hline 1949 & 1.23 & 0.11 & 0.40 & 2.14 & 0.40 & 1.19 \\
\hline 1950 & 1.51 & 0.37 & 1.19 & 2.76 & 0.92 & 2.59 \\
\hline 1951 & 1.68 & 0.75 & 2.41 & 3.15 & 1.12 & 3.20 \\
\hline 1952 & 1.48 & 0.57 & 1.86 & 2.61 & 0.97 & 2.86 \\
\hline 1953 & 1.28 & 0.19 & 0.70 & 2.13 & 0.58 & 1.95 \\
\hline 1954 & 1.40 & 0.33 & 1.37 & 2.32 & 0.57 & 2.25 \\
\hline 1955 & 1.40 & 0.36 & 1.28 & 2.25 & 0.64 & 2.32 \\
\hline 1956 & 1.26 & 0.12 & 0.46 & 1.96 & 0.29 & 0.88 \\
\hline 1957 & 1.61 & 0.58 & 2.29 & 2.56 & 1.02 & 2.77 \\
\hline 1958 & 2.02 & 0.82 & 2.38 & 3.22 & 1.29 & 2.99 \\
\hline 1959 & 1.26 & 0.09 & 0.37 & 1.96 & 0.30 & 1.16 \\
\hline 1960 & 1.45 & 0.38 & 1.19 & 2.56 & 1.05 & 3.02 \\
\hline 1961 & 1.56 & 0.61 & 2.16 & 2.62 & 1.03 & 3.29 \\
\hline 1962 & 1.39 & 0.16 & 0.49 & 1.81 & 0.50 & 1.61 \\
\hline 1963 & 1.26 & 0.10 & 0.33 & 1.83 & 0.19 & 0.76 \\
\hline 1964 & 1.28 & 0.09 & 0.37 & 2.00 & 0.45 & 1.86 \\
\hline 1965 & 1.45 & 0.24 & 0.91 & 2.50 & 0.77 & 2.22 \\
\hline 1966 & 1.26 & 0.08 & 0.33 & 1.97 & 0.46 & 1.89 \\
\hline 1967 & 1.34 & 0.17 & 0.64 & 2.24 & 0.57 & 1.74 \\
\hline 1968 & 1.60 & 0.54 & 1.83 & 2.40 & 0.84 & 2.71 \\
\hline 1969 & 1.59 & 0.29 & 0.76 & 2.81 & 0.86 & 2.41 \\
\hline 1970 & 2.05 & 0.81 & 2.35 & 3.43 & 1.25 & 3.38 \\
\hline 1971 & 1.37 & 0.09 & 0.46 & 2.00 & 0.23 & 0.88 \\
\hline 1972 & 2.27 & 0.48 & 1.58 & 3.64 & 0.51 & 2.10 \\
\hline 1973 & 1.75 & 0.71 & 2.32 & 2.94 & 1.24 & 3.63 \\
\hline 197.1 & 2.01 & 1.22 & 3.41 & 3.15 & 1.92 & 5.33 \\
\hline 1975 & 1.65 & 0.61 & 2.01 & 2.63 & 0.99 & 2.86 \\
\hline 1976 & 1.37 & 0.14 & 0.52 & 2.04 & 0.47 & 1.65 \\
\hline
\end{tabular}

son the Henry gauge $O=130.81 \mathrm{~m}(429.19 \mathrm{ft}) \mathrm{ms}$.

b On the Hilvana gatuge $O=129.31 \mathrm{~m}(42.28 \mathrm{ft}) \mathrm{msl}$.

" Ratnge is the difference betwees extremes.

they were exposed. Extrente means in weekly water levels altest (in most cases) to the wide range in river levels during the growing season. Because of the navigation dams, minimum levels were relatively constant from year to year; high water cansed the wide range above the means. The Peoria and La Gange navigation dams combined with diverted water to stabilize the lowwiter profile of the river. Low-water recorts al Peoria, 1902-1938, averaged
$133.4 \mathrm{~m}(137.5 \mathrm{ft})$ with a standard deviation of $0.3 \mathrm{~m}$ (1.1 ft); from 1939 to 1975, the elevation averaged $133.8 \mathrm{~m}$ (139.0 $\mathrm{ft}$ ) with a standard deviation of only $0.1 \mathrm{~m}(0.3 \mathrm{ft})$.

\section{WETLAND VEGETATION}

Althongh lllinois Valley lakes have manty similarities in gross alppearance, sublle differences occur among $1 \mathrm{hem}$. Consequently, a classification system for the lakes is difficult to develop, but 
to facilitate our discussion, we use the following groups.

The lakes are grouped according to their water-level stability (Classes I-IV) and by periods: 1938-1942, 1943, and 1944-1959. The highest flood on record occurred during May and June of 1943. We sought to determine the effect of this tremendous flood on wetland vegetation both in the year it occurred and in following years.

Table 3 lists the areas covered by wetland plants in six lakes connected with the river at all stages (Class I) from 1938 to 1942. River bulrush was the most abundant species, covering an average of 7.3 percent of the lake basins; American lotus averaged 6.1 percent; and marsh smartweed and luck potato each had about 2 percent. Other wetland species were of only minor occurrence, and all species together covered only 24.2 percent of the lake basins.

Average areas covered by wetland plants in six lakes that were separated from the river by barriers at moderately low stages (Class 11) are shown in $\mathrm{Ta}$ ble 4. Many of the plant species in these lakes belong to an ecological com-

Table 3.-The average abundance by area of wetland plants in bottomland lakes connected with the Illinois River at all water stages (Class I), 1938-1942. Figures are in hectares (2.47) acres/hectare).

\begin{tabular}{|c|c|c|c|c|c|c|c|c|}
\hline Species & $\begin{array}{c}\text { Saw- } \\
\text { mill } \\
\text { 1938- } \\
1941^{*}\end{array}$ & $\begin{array}{c}\text { Spar- } \\
\text { land } \\
1939- \\
1941\end{array}$ & $\begin{array}{c}\text { Babbs } \\
1941- \\
1942\end{array}$ & $\begin{array}{c}\text { Quiver } \\
\text { 1938- } \\
1941\end{array}$ & $\begin{array}{c}\text { Tread- } \\
\text { way } \\
1938- \\
1941\end{array}$ & $\begin{array}{c}\text { Muscoo- } \\
\text { ten } \\
1938- \\
1941\end{array}$ & $\begin{array}{l}\text { Total } \\
\text { Aver- } \\
\text { age } \\
\text { Hec- } \\
\text { tares } \\
\text { per } \\
\text { Year } \\
\text { in } \\
\text { Vegeta- } \\
\text { tionb }\end{array}$ & $\begin{array}{c}\text { Per- } \\
\text { cent } \\
\text { of } \\
\text { Basin } \\
\text { in } \\
\text { Vegeta- } \\
\text { tion }\end{array}$ \\
\hline Cattail & $\ldots$ & $\ldots$ & .. & . & 0.3 & 1.8 & 2.1 & 0.1 \\
\hline Giant bur-reed & $\ldots$ & $\ldots$ & $\ldots$ & $\ldots$ & 2.4 & 4.5 & 6.9 & 0.3 \\
\hline Longleaf pondweed & $\ldots$ & $\ldots$ & 0.9 & trace & 1.1 & 13.1 & 15.1 & 0.7 \\
\hline Leafy pondweed & $\ldots$ & $\ldots$ & $\ldots$ & $\ldots$ & $\ldots$ & 0.1 & 0.1 & trace \\
\hline Sago pondweed & 15.0 & 0.3 & 0.7 & 0.6 & 3.1 & 1.4 & 21.1 & 0.9 \\
\hline Southern naiad & & $\ldots$ & $\ldots$ & $\ldots$ & & 0.1 & 0.1 & trace \\
\hline Duck potato & 0.8 & $\ldots$ & 5.4 & 4.0 & 21.7 & 13.8 & 45.7 & 2.0 \\
\hline Waterweed & $\ldots$ & $\ldots$ & 6.2 & 0.1 & $\ldots$ & $\ldots$ & 6.3 & 0.3 \\
\hline Rice cutgrass & $\ldots$ & $\ldots$ & $\cdots$ & 0.9 & $\ldots$ & 0.7 & I. 6 & 0.1 \\
\hline Wild millet & $\ldots$ & $\ldots$ & $\ldots$ & 5.3 & $\ldots$ & $\ldots$ & 5.3 & 0.2 \\
\hline Nutgrasses & 0.5 & $\ldots$ & ... & 9.1 & $\ldots$ & $\ldots$ & 9.6 & 0.4 \\
\hline American bulrush & $\ldots$ & $\ldots$ & $\ldots$ & 1.4 & $\ldots$ & $\ldots$ & 1.4 & 0.1 \\
\hline Hardstem bulrush & $\ldots$ & $\ldots$ & $\ldots$ & $\ldots$ & 0.3 & $\ldots$ & 0.3 & trace \\
\hline River bulrush & 48.7 & 17.7 & 95.6 & 0.4 & 0.4 & 22 & 165.0 & 7.3 \\
\hline Spike rush & 0.1 & $\ldots$ & & 2.1 & 5.6 & 0.5 & 8.3 & 0.4 \\
\hline Duckweeds & 4.0 & $\ldots$ & 40.3 & $\ldots$ & ... & ... & 44.3 & 2.0 \\
\hline Pickerel weed & $\ldots$ & 0.4 & 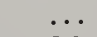 & $\ldots$ & $\ldots$ & $\ldots$ & 0.4 & trace \\
\hline Water stargrass & $\ldots$ & $\ldots$ & 0.1 & $\ldots$ & $\ldots$ & I.0 & 1.1 & 0.1 \\
\hline Marsh smartweed & 2.0 & 11.6 & 0.4 & 0.8 & 5.7 & 25.9 & 46.4 & 2.1 \\
\hline Nodding smartweed & $\ldots$ & 1.0 & $\ldots$ & $\ldots$ & $\ldots$ & $\cdots$ & 1.0 & trace \\
\hline Water hemp & $\ldots$ & $\ldots$ & $\ldots$ & 8.7 & ... & $\ldots$ & 8.7 & 0.4 \\
\hline Coontail & $\ldots$ & $\ldots$ & 13.6 & trace & $\ldots$ & 0.3 & 13.9 & 0.6 \\
\hline American lotus & 24.0 & $\ldots$ & $\ldots$ & $\ldots$ & 30.1 & 84.3 & 198.4 & 6.1 \\
\hline Marsh mallow & 0.2 & 1.1 & $\ldots$ & $\ldots$ & $\ldots$ & $\ldots$ & 1.3 & 0.1 \\
\hline Totaluegetation & 95.3 & 32.1 & 163.2 & 33.4 & 70.7 & 149.7 & 544.4 & ... \\
\hline Lake basin arca & 398.6 & 419.3 & 339.9 & 212.5 & 253.7 & 628.1 & $2,252.1$ & $\ldots$ \\
\hline Vegetation pcrcentage & 23.9 & 7.7 & 48.0 & 15.7 & 27.9 & 23.8 & 24.2 & $\ldots$ \\
\hline Open-water percentage & 76.1 & 92.3 & 52.0 & 84.3 & 72.1 & 76.2 & 75.8 & ... \\
\hline
\end{tabular}

- Averages for the lime period involved.

Sum of the averages of all lakes. 


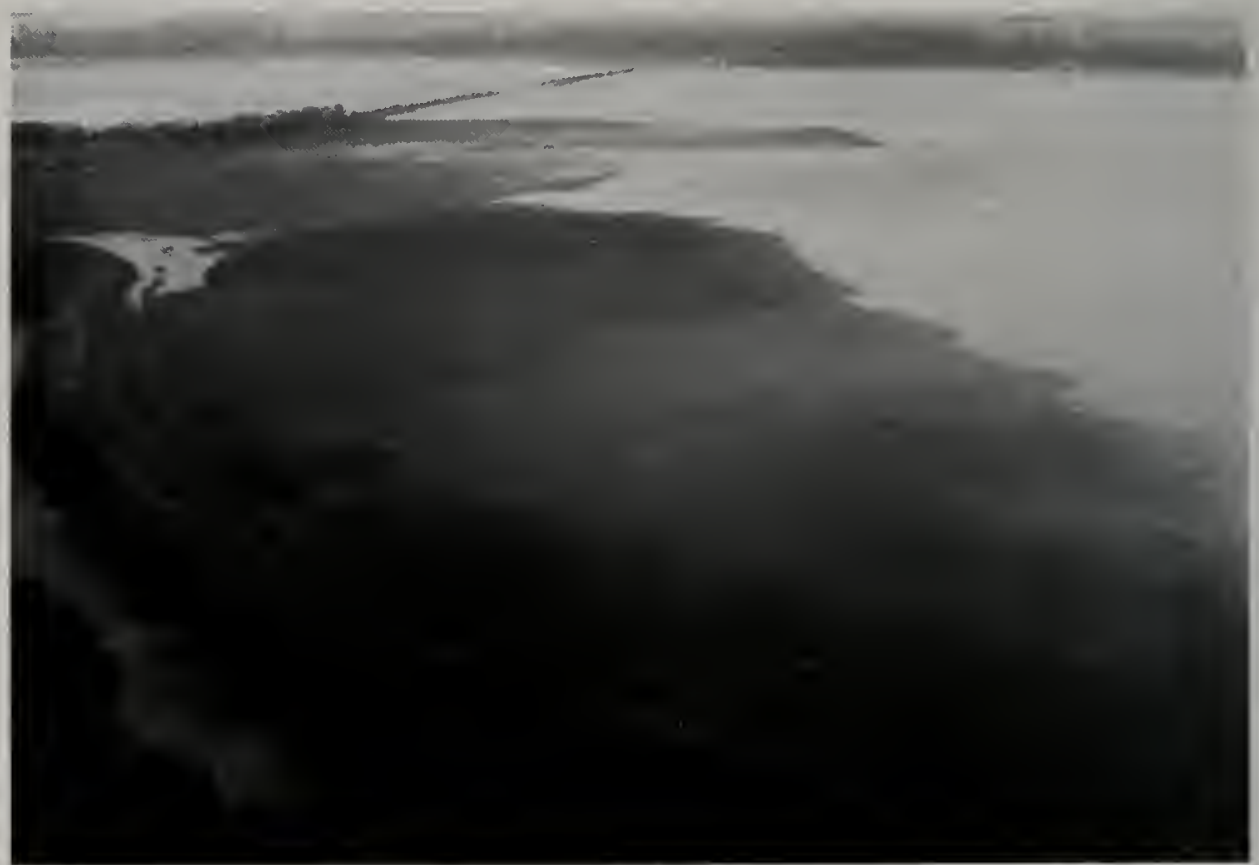

Fig. 4.-Extensive mud flats exposed on the west shore of Lake Chautauqua (Class II) a few miles north of Havana. Mud flats like these are colonized by plant species that belong to an ecological community termed moist-soil plants.

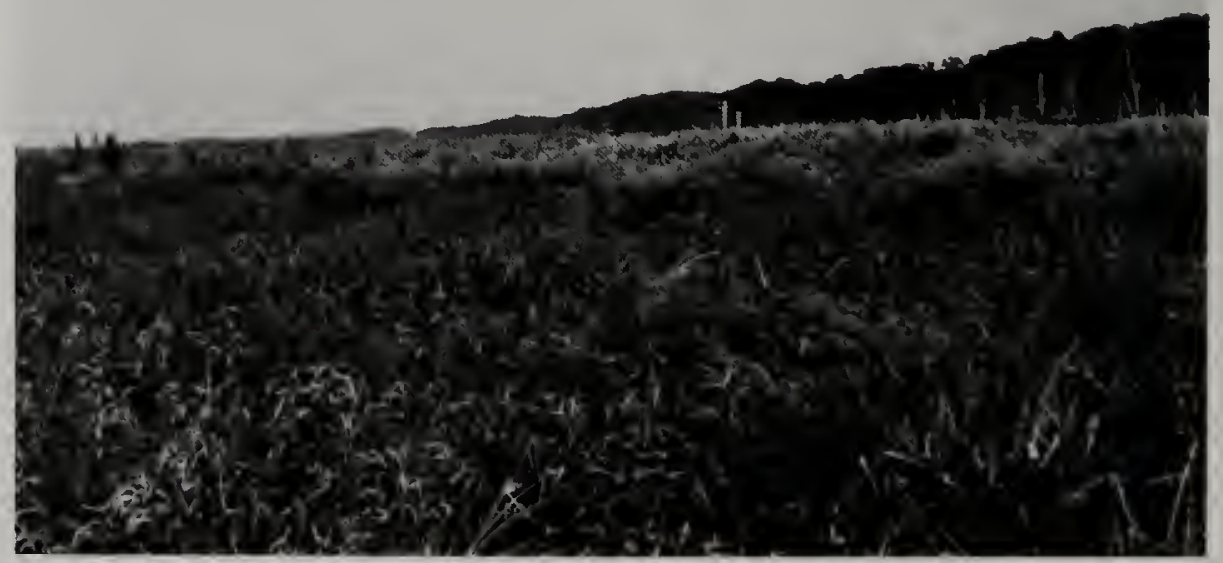

Fig. 5. - Lush stands of moist-soil plants at Spring Lake. These stands occurred when mud flats were exposed early during the summer growing season, 1978. 


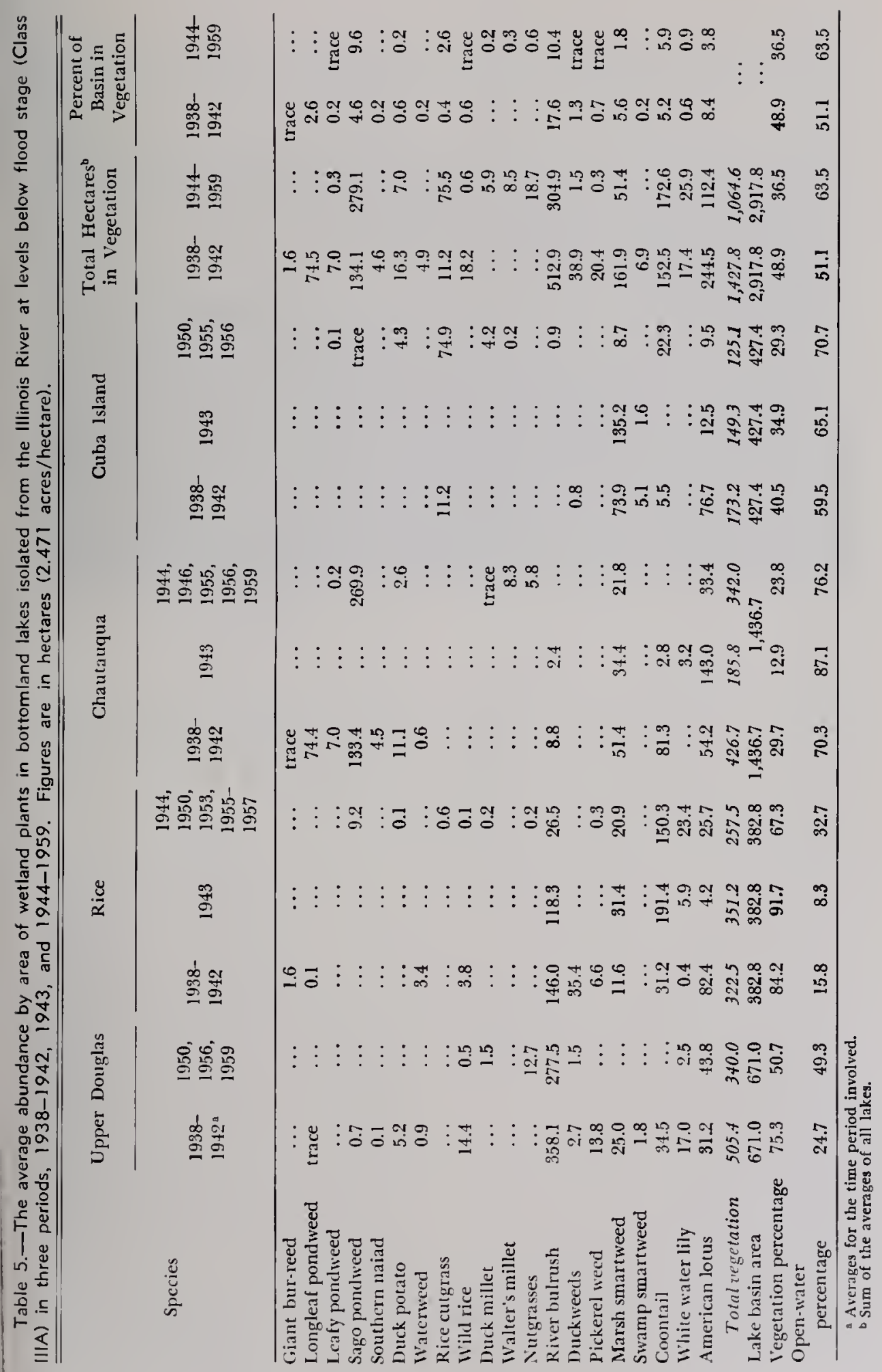


munity associated with mud flats, and are termed moist-soil plints (Fig. 4 and 5). These plants include: teal grass; rice cutgrass; wild, Japanese, and Walter's millet; nutgrasses; nodding and largeseed smartweed; water hemp; cockleburs; and Spanish needles. They covered 11.3 percent of the lake basins in 1938-1942, and 13.3 percent in 1944-1959. In contrast, the moist-soil species present in Class I lakes (Table 3) were limited to rice cutgrass, wild millet, nutgrasses, nodding smartweed, and water hemp; they aggregated a mere 1.1 percent of those lake basins from 1938 to 1942.

Arrowleaf covered averages of 0.8 and 1.8 percent of the Class II lake basins in 1938-1942 and 1944-1959, respectively. In both Class I and Class II lakes river bulrush covered almost the same average proportion of lake basins ( 7.3 and 5.3 percent, respectively), but American lotus expanded its coverage from 6.1 percent in Class I lakes to 17.1 percent in Class II lakes. Increases also occurred in the areas covered by aquatic pondweeds, southern naiad, waterweed, and coontail: they totaled 5.2 percent of Class II lake basins, 1938-1942, and 12.2 percent, 1914-1959. up from 2.5 percent present cluring the former period in Class I lakes. From 1938 to 1912 marsh smartweed more than doubled in abundance in Class II over Class 1 lakes, but cluck potato was less abundant (probal)ly because of competition with marsh smartweed). All wetland plants covered 46.8 percent of Class II lakes in 1938-19-12, and 58.4 percent in 1944-1959.

Class IIl lakes are only affected by river levels when flood waters top the natural banks that lie betwcen lake and river. Four lakes in Class IIIA were studied during 1938-1959 (Table 5). Species of retland plants in Class IIIA lakes were similar to those foumd in Class II lakes; moreover, the proportion of wetland regetation in the lake basins was similar to the percentage
(46.8) in Class II lakes during the first period (48.9 percent) but was less in the second period ( 36.5 percent).

However, there were pronounced differences in the relative abundance of certain species of plants between Class IIIA and Class II lakes. Pondweeds, southern naiad, and waterweed were more abundant in Class IIIA lakes, covering 7.8 percent of the lake basins in 1938-1942, and 9.6 percent in I9491959, compared with 2.3 and 5.0 percent, respectively, in Class II lakes (Fig. 6). Coontail was more abundant in Class IIIA lakes than in Class II lakes during the first period but was less abundant in the Class IIIA lakes than in Class II lakes during the second period (Table 5). Wild rice and pickerel weed, unusual marsh plants in Illinois, were noticeably present prior to the 1943 flood. River bulrush was also proportionately more abundant in Class IIIA lakes than in lakes of the other classes.

Moist-soil plants were almost absent ( 0.6 percent) from Class IIIA lakes during the first perioul and of slight abundance during the second period (3.7 percent), much less than in Class II lakes.

Class IIIB lakes must be dewatered by 1 August in central Illinois to produce moist-soil plants consistently. Otherwise, the growing season is too short for the plants to mature and produce an abundant seed crop. Dewatering by 15 July provides a still more favorable growing period. Prolonged spring flook may make dewatering infeasible in certain ycars, and midsummer lloods may wipe out moist-soil plants well along in growth. Some lloods occur so latc that the time remaining in the growing season is 100 short for the development of another plant gencration.

Table 6 shows wetland regetation areas, averaged for a number of years, at three Class IIIB lakes. Moist-soil species covered 41.7 percent of the lake 


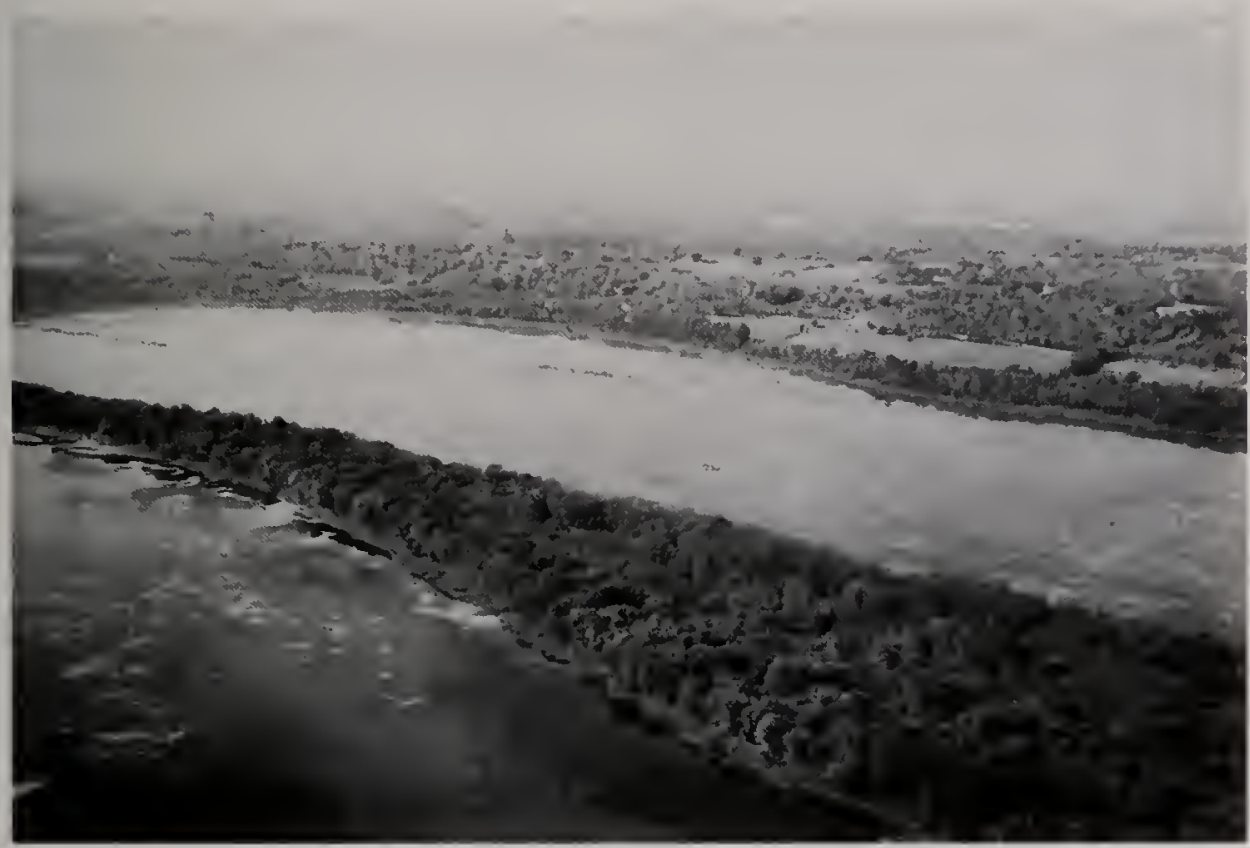

Fig. 6.-Abundant growth of aquatic plants, primarily coontail, present in Rice Lake (Class IIIA) during the summer of 1953

Table 6.- The average abundance by area of wetland plants in bottomland lakes separated from the Illinois River at levels below flood stage and intensively managed by dewatering (Class IIIB), 1946-1959. Figures are in hectares (2.471 acres/hectare).

\begin{tabular}{|c|c|c|c|c|c|}
\hline \multirow[b]{2}{*}{ Species } & \multirow{2}{*}{$\begin{array}{c}\text { Bath } \\
1946-1949^{\mathrm{a}}\end{array}$} & \multirow{2}{*}{$\begin{array}{c}\text { Moscow } \\
1946,1950 \\
195.5,1956 \\
1959\end{array}$} & \multirow{2}{*}{$\begin{array}{c}\text { Ingram } \\
1955, \\
1956,1959\end{array}$} & \multirow{2}{*}{$\begin{array}{c}\text { Hectares } \\
\text { in } \\
\text { Vegetation } \\
\text { per } \\
\text { Vear }{ }^{\circ}\end{array}$} & \multirow{2}{*}{$\begin{array}{l}\text { Percent } \\
\text { of } \\
\text { Basin in } \\
\text { Vegetation }\end{array}$} \\
\hline & & & & & \\
\hline Longlcaf pondweed & $\ldots$ & $\ldots$ & 0.4 & 0.4 & 0.1 \\
\hline Sago pondweed & $\ldots$ & $\ldots$ & 0.1 & 0.1 & trace \\
\hline Arrowleaf & $\ldots$ & $\ldots$ & 8.0 & 8.0 & 1.3 \\
\hline Duck potato & 0.3 & 1.0 & 0.7 & 1.0 & 0.2 \\
\hline Teal grass & 1.7 & 1.1 & 10.1 & 12.9 & 2.1 \\
\hline Rice cutgrass & 4.5 & 13.4 & 12.6 & 30.6 & 5.0 \\
\hline Wild millet & 0.7 & 0.6 & 8.9 & 10.2 & 1.7 \\
\hline Japanese millet & 8.5 & 14.5 & 79.6 & 102.6 & 16.9 \\
\hline WaIter's millet & 3.2 & 5.4 & 2.2 & 10.8 & 1.8 \\
\hline Nutgrasses & 4.6 & 2.9 & 55.7 & 63.2 & 10.4 \\
\hline River bulrush & $\ldots$ & 0.2 & 18.8 & 19.0 & 3.1 \\
\hline Marsh smartweed & $\ldots$ & 0.4 & 5.8 & 6.2 & 1.0 \\
\hline Water hemp & 2.0 & 1.4 & 8.8 & 12.9 & 2.0 \\
\hline American lotus & $\ldots$ & $\ldots$ & 3.5 & 3.5 & 0.6 \\
\hline Cocklebur & 1.0 & $\ldots$ & 7.0 & 8.0 & 1.3 \\
\hline Spanish needles & 1.1 & 0.2 & $\ldots$ & 1.3 & 0.2 \\
\hline Other moist-soil plants & 1.3 & $\ldots$ & ... & 1.3 & 0.2 \\
\hline Tolal vegetation & 28.9 & 41.1 & 222.2 & 291.3 & $\ldots$ \\
\hline Lake basin arca & 63.9 & 108.0 & 435.9 & 607.8 & $\cdots$ \\
\hline Vegetation percentage & 45.2 & 38.0 & 51.0 & 47.9 & 47.9 \\
\hline Open-water pereentage & 54.8 & 62.0 & 49.0 & 52.1 & 52.1 \\
\hline
\end{tabular}

Averages for the lime period involved.

b Sum of the averages of all lakes. 
basins, and 6.2 percent was covered by other species. Artificially sown Japanese millet composed nearly half of all moist-soil plants; the other species occurred naturally. Nutgrasses, rice cutgrass, teal grass, water hemp, and Walter's millet and wild millet were the principal species, listed in descending order of abundance.

Marsh plants-river bulrush (3.1 percent), arrowleaf (1.3 percent), marsh smartweed ( 1.0 percent), and duck potato (0.2 percent)-aggregated 5.6 percent (Table 6) in Class II1B, a much smaller proportion of the area than they covered in other classes of lakes.

Aquatic plants were almost nonexistent in Class IIIB lakes. Longleaf and sago pondweed $(0.1$ percent and trace, respectively) and American lotus (0.6 percent) totaled only 0.7 percent of the lake basins. These aquatics occurred because the lakes were never completely drained; usually from one-third to onehalf of the lake basin retained a shallow residne of water surrounded by bare mud flats and shoreward, by zones of moist-soil plants.

\section{EVALUATION OF THE SEVERANCE OF LAKES FROM THE RIVER}

Data presented in Tables 3-6 show that the greater the separation of the lake basin from the Illinois River, the more productive the lake was of wetland plants. Although after the 1943 flood, the percentage of the lake basins covered by aquatic and marsh plants in Class IIIA lakes declined below levels in Class 11 lakes, this difference occurred for other reasons that will be discussed later under water depth and turbidity.

Not only did the quantity of wetland plants increase with the degree of isolation from the river water, but the cyuality of vegetation for waterfowl food also improved. In Class I lakes, river buluush, American lotus, and marsh smartweed made up 64 percent of the wetland plants, but their production of waterfowl food was minute (Low \& Bellrose 1944).

River bulrush produces a negligible amount of seeds; American lotus produces a moderate seed crop, but its seeds are too hard for ducks to eat during the fall (Bellrose \&. Anderson 1943); and marsh smartweed fails to produce seed when growing out of water (Low \& Bellrose 1944), as it does in most Class I lakes.

Class II lakes produced more moistsoil plants than did Class IIIA lakes, but Class IIIA had a greater abundance of aquatic and marsh plants. The maximum waterfowl food plant procluction occurred in Class liIB lakes because of the extensive development of moist-soil vegetation resulting from controlled drawdowns of water. Most moist-soil plants yield large crops of seed (Low \& Bellrose 1944) that are preferred foods of most dabbling ducks (Bellrose \& Anderson 1943).

Plants most typical of all classes of Illinois Valley lakes are river bulrush, American lotus, and marsh smartweed. These species in their respective niches are obviously the most adaptable to a regimen of fluctuating water levels.

Within each class of lakes, the abundance of wetland plants changes from year to year as the water level fluctuations vary.

\section{EVALUATION OF SEASONAL CHANGES IN BOTTOMLAND LAKE WATER LEVELS}

\section{Effects on Moist-Soil Plants}

A comparison of the yearly MoistSoil Water-I.evel Index (described under Methods) and the development of moist-soil plants in the lake basins of the lower lllinois River valley is shown in Fig. 7. (At the time of the sturly, mud flats were not extensively exposed in the valley above Peoria because the Peoria lock and dam had raised water levels.) As the yearly Moist-Soil WaterLevel Index rose, the proportion of all 


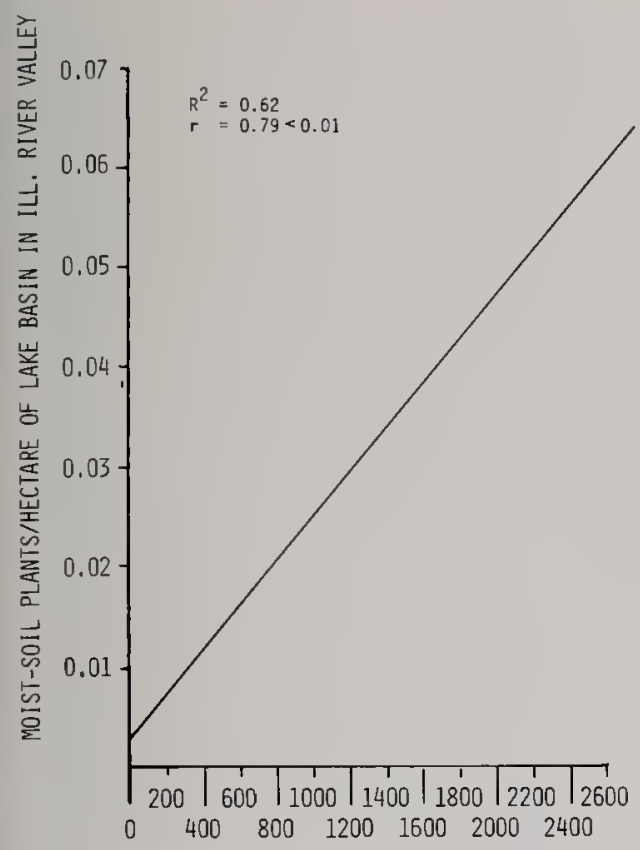

MOIST-SOIL WATER-LEVEL INDEX

Fig. 7.-The linear relationship of the Moist-Soil Water-Level Index to the abundance of moist-soil plants per hectare of lake basin in the Illinois River valley.

lake basins covered with moist-soil plants likewise increased. The coefficient of determination $\left(\mathrm{R}^{2}=0.62\right)$ indicates that about 60 percent of the annual coverage of moist-soil plants was related to the Moist-Soil WaterLevel Index.

Small rises in water during the growing season of moist-soil plants lestroyed extensive areas of these plants, the extent depending upon the height of the rise and the lateness of the season. The havoc that these midsummer fluctuations wrought on the development of moist-soil plant beds is only partially measured by the MoistSoil Water-Level Index and is the principal reason that it accounted for only 60 percent of the plants' coverage of lake basins. Once eradicated by a brief inmudation, moist-soil plants might not have sufficient time to regenerate, or mud flat areas might be reduced.

\section{Effects on Aquatic and Marsh Plants}

Through the years, 1938-1959, only a small coefficient of determination occurred between the area covered yearly by aquatic and marsh plants and the yearly variation in the seasonal fluctuation of water levels. The WaterStability Index for seasonal stability on all lakes studied compared with the development of marsh vegetation gave a coefficient of determination of 0.11 (1l percent of the variable accounted for by fluctuating levels); for aquatic plants it was 0.108 (10.8 percent).

Two items were proposed for further analysis: (1) Water levels had various effects on aquatic and marsh plants in different lakes that we attributed to different elevations and bottom topographies of the lake basins. (2) Factors other than the degree of water-level stability appeared to be more important in regulating the growth of aquatic and marsl plants.

To evaluate further the effects that yearly variation in the fluctuation of water levels had on aquatic and marsh plants, we examined particular Class IIIA lakes more closely.

Lake Chautauqua.-One of our longest series of aquatic plant studies was made at Lake Chautauqua, a national wildlife refuge. The 1,416-ha $(3,500$-acre) lake is enclosed by levees that minimize low-water fluctuations. A spillway at $133.4 \mathrm{~m}(437.5 \mathrm{ft}) \mathrm{msl}$ permitted river waters above that height to enter the lake during the years of the study. Unfortunately, refuge gauge records are available for only 8 of the 14 years studied.

The Water-Stability Index for those 8 years was compared to the occurrence of sago pondweed by linear regression. The coefficient of determination was 0.31 , suggesting that water stability accounted for about 30 percent of the yearly change in abundance of sago pondweed. American lotus, coontail, river bulrush, and duck potato showed 
only a slight correlation between their abundance and the Water-Stability Inclex.

The lighest flood on record in the Illinois River valley occurred in late May 1943. At Lake Chautauqua the flood crested on 25 May, $5.3 \mathrm{~m}$ (17.5 ft) above the normal lake level. It inundated other Class IIIA lakes to similar depths. Vegetation studies were made in late summer after the water level had returned to normal.

The flood eradicated all pondweeds from Lake Clautauqua (Table 5); coontail declined greatly in 1943 and never recovered in subsequent years; marsh smartweed and river bulrush also suffered losses in abundance that were never regained. American lotus increased in abundance but subsequently died out in the early 1960's.

RICE LAKE.-At Rice Lake, coontajl abundance increased markedly in 1943, apparently because of less competition from American lotus (Table 5). The high water lessened the area of river bulrush on lower sites, enabling marsh smartweed to invade stands of bulrush and increase in abundance. Flood waters submerged the growing plants of lotus so deeply that they failed to recover after the water subsided, perlıaps enabling white water lily to increase.

Cuba IsLand.-Flood waters adversely affected the abundance of rice cutgrass, coontail, and American lotus at Cuba Island (Table 5). Marsh smartweed, lowever, increased as competition from other plants decreased.

Flat, Swan, ANd Gilbert Lakes.Flat, Swan, and Gilbert lakes, part of the Callsoun Division of the Mark Twain National Wildlife Refuge, lie in the lower Illinois River valley a few miles above the river's confluence with the Mississippi River.

Several relatively small lakes occurred there before 1939. At that time the Alton navigation dam raised water levels, increasing the lakes' surface area from 445 to 1,943 ha $(1,100-4,800$ acres). By 1941, wetland plants had developed in a sizeable area where little but lotus had grown before the expansion of Flat, Swan, and Gilbert lakes in 1939 (Table 7).

However, the flood of 1943 caused a marked reduction in wetland regetation, and the plants appeared late in the growing season after the flood had subsided. The comeback of wetland plants was retarded in 1944 by another high flood in the late spring.

During most of the $1960^{\circ}$ s, sago and longleaf pondweeds, southern naiad, and coontail flourished in Swan Lake. Beds of these aquatics aggregated 405 ha $(1,000$ acres) in 1965 , but a late September flood reduced their fall availability to waterfowl. A high flood in April and a minor one in June

Table 7.-The abundance by area of wetland plants at Flat, Swan, and Gilbert lakes, 1941-1944. Figures are in hectares (2.471 acres/hectare).

\begin{tabular}{|c|c|c|c|c|}
\hline Species & 1941 & 1942 & 1943 & 1944 \\
\hline Caltail & $\ldots$ & 29.3 & 0.4 & .. \\
\hline Longleaf & & & & \\
\hline $\begin{array}{l}\text { pondweed } \\
\text { Icafy }\end{array}$ & 10.0 & $\cdots$ & $\cdots$ & $\cdots$ \\
\hline pondweed & 0.9 & $\ldots$ & $\cdots$ & $\cdots$ \\
\hline Sago & & & & \\
\hline pondweed & 0.6 & $\cdots$ & $\ldots$ & $\cdots$ \\
\hline Southern & & & & \\
\hline $\begin{array}{l}\text { naiad } \\
\text { Duck }\end{array}$ & 16.8 & $\cdots$ & $\cdots$ & $\cdots$ \\
\hline polato & 0.8 & $\ldots$ & 8.7 & $\ldots$ \\
\hline Arrowleaf & 18.0 & 6.3 & 9.6 & 10.8 \\
\hline Rice & & & & \\
\hline cutgrass & 14.1 & 13.9 & 4.7 & ... \\
\hline $\begin{array}{l}\text { Wild } \\
\text { millet }\end{array}$ & & $\cdots$ & $\ldots$ & 2.8 \\
\hline Nutgrasses & 68.2 & 54.4 & 9.0 & 9.2 \\
\hline Sofistem & & & & \\
\hline $\begin{array}{l}\text { bulrush } \\
\text { Spike }\end{array}$ & 0.4 & 0.3 & $\ldots$ & .. \\
\hline rusl & 2.4 & $\ldots$ & 0.2 & $\cdots$ \\
\hline $\begin{array}{l}\text { Marsh } \\
\text { smartweed }\end{array}$ & $\ldots$ & 19.3 & 20.9 & 8.9 \\
\hline $\begin{array}{l}\text { Coomtail } \\
\text { White water }\end{array}$ & 22.0 & $\ldots$ & $\ldots$ & $\ldots$ \\
\hline $\begin{array}{l}\text { lily } \\
\text { American }\end{array}$ & $\cdots$ & $\cdots$ & 0.4 & $\cdots$ \\
\hline lotus & 34.2 & $\ldots$ & 13.2 & 61.2 \\
\hline Marsl & & & & \\
\hline mallow & $\cdots$ & $\cdots$ & 0.2 & $\cdots$ \\
\hline $\begin{array}{l}\text { Total } \\
\text { vegeta- } \\
\text { lion }\end{array}$ & $1 S S .4$ & 123.5 & 67.3 & 92.9 \\
\hline
\end{tabular}


1967 resulted in turbid water through much of the growing season, limiting the growth of submerged aquatics but not that of American lotus or duck potato. Stable water levels prevailed during the growing season and fall of 1968, promoting an excellent growth of sago and longleaf pondweeds, southern naiad, and coontail.

Three floods occurred in 1969: spring, July, and October. After the spring flood, beds of submerged aquatics and American lotus began to appear, only to he clestroyed by high, turbicl water in July. In spite of favorable water levels in 1971 and I976, acuatic plants did not reestablish themselves in Flat and Swan lakes. Large depositions of new sediments were resuspended by wave and fish activity, greatly increasing turbidity.

Yearly fluctuations in water levels have an influence on aquatic and marsh plants, but such fluctuations are less important to the welfare of these plants than they are to moistsoil species. It is also apparent that factors other than water-level stability have influenced the growth of aquatic and marsh plants. Therefore, we evaluated several other factors.

\section{CHANGES IN WATER DEPTHS}

Semipermanent changes in water clepth profoundly affected the vegetation at several Illinois Valley lakes: Rice, Douglas, Spring, and Anderson.

\section{Rice Lake}

In 1945 an earthen dam was constructed at the outlet of Rice Lake, increasing its normal minimum depth by $0.4 \mathrm{~m}(1.3 \mathrm{ft})$. In 1953 the dam was raised an additional $0.5 \mathrm{~m}(1.5 \mathrm{ft})$ and another $0.4 \mathrm{~m}$ (1.3 ft) in 1961 .

These increases in water level at Rice Lake severely altered its plant communities. With a clepth increase of $0.4 \mathrm{~m}$ ( $\mathrm{I} .3 \mathrm{ft}$ ) in 1945 , river bulrush declined from covering over 33 percent of the basin to merely 1.7 and 1.0 per- cent in 1950 and 1953, respectively (Table 8). With low water levels in 1977 and 1978, about 10.1 ha (25 acres) of river bulrush have become reestablished. The abundance of marsh smartweed varied from year to year with spring water conditions; it covered a larger area in 1955-1956 after the water was raised an additional $0.5 \mathrm{~m}$ (1.5 ft) during 1953. Marsh smartweed invaded areas formerly occupied by river bulrush but could not tolerate the rising water and disappeared in the 1960 's.

American lotus declined in abundance from 15.1 percent of the Rice Lake area in 1944 to a trace in 1956 and none in 1957. Small beds of lotus reappeared in 1977 and 1978 as water levels were lowered.

In the 1950's, coontail markedly increased in arca as a result of the deeper water (Table 8). It invaded areas vacated by declining beds of lotus and river bulrush. However, the disappearame of river bulrush and lotus increasingly exposed a greater expanse ol open water to wave action. Waves resuspend highly organic bottom materials, causing the waters to become much more turbid than before. As a result of increased turbidity, coontail vanished from Rice Lake in the mid1960's and has not become reestablished.

White water lily increased in abundance as competition from lotus lessened and as water levels remained more stable. However, it could not toleratc the increasing wave action and turbidity of the carly 1960's and eventually disappeared from the lake.

\section{Douglas Lake}

With the inauguration of the Peoria lock and lam in December 1938, the minimum water level at Douglas Lake was raised alyout $0.6 \mathrm{~m}$ (2 ft). At that time the area supported the largest river bulrush marsh in the state (364.1 ha, 899.7 acres; Table 9). Over the 


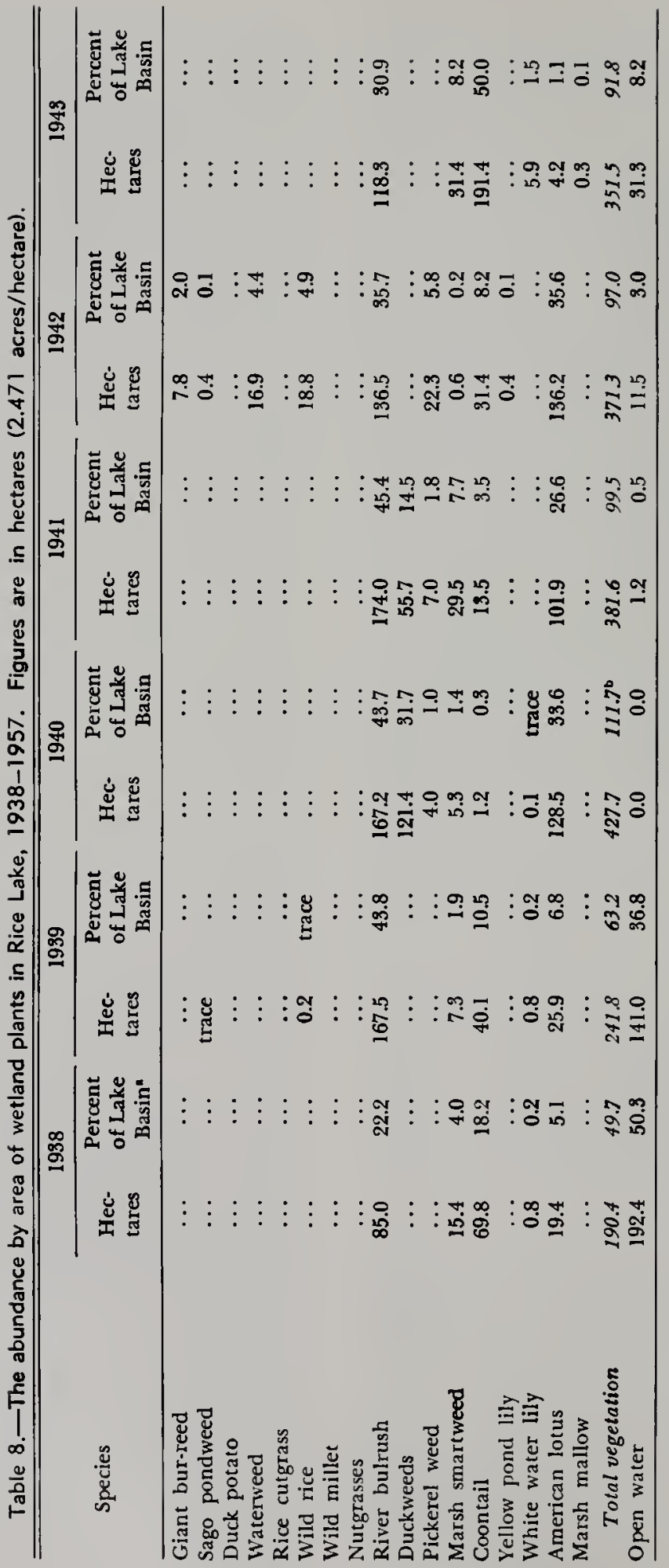




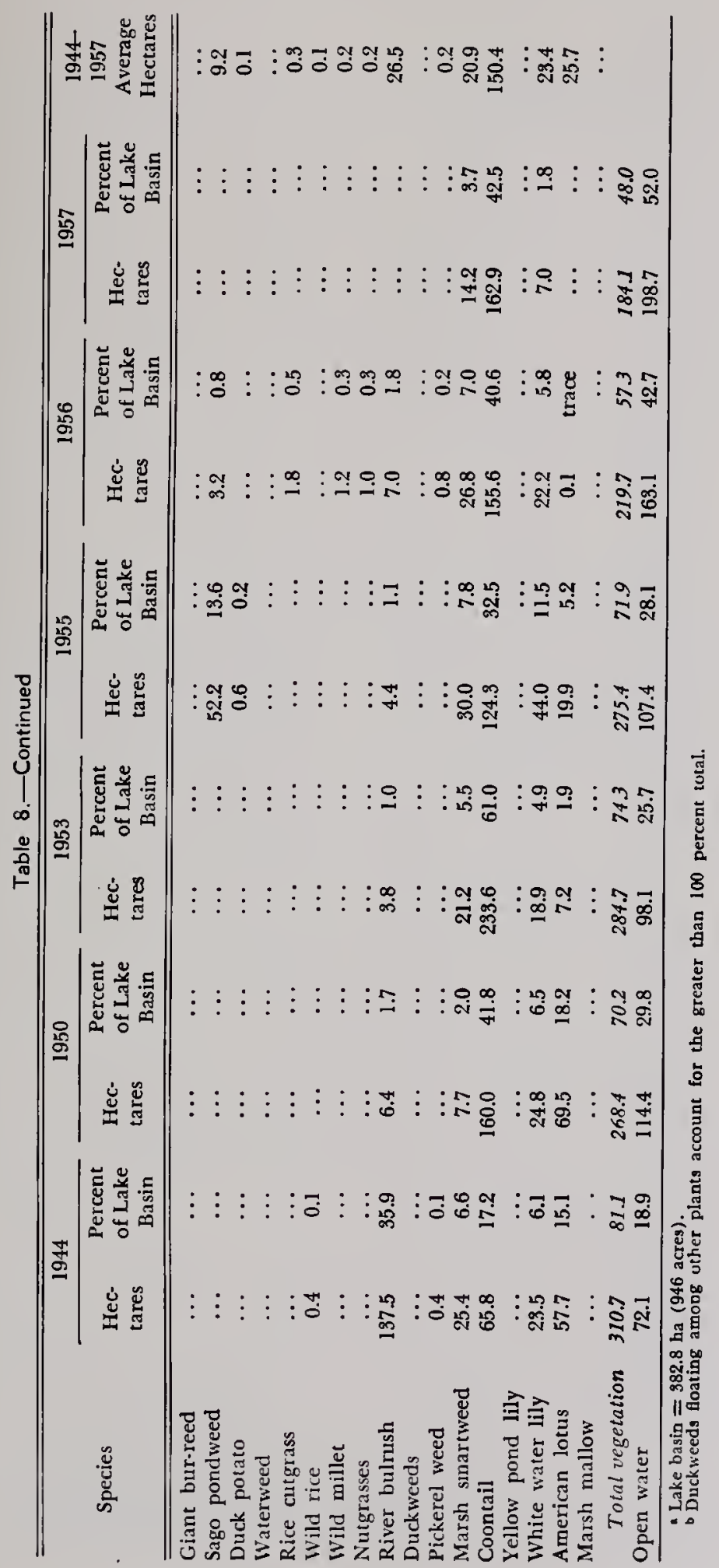




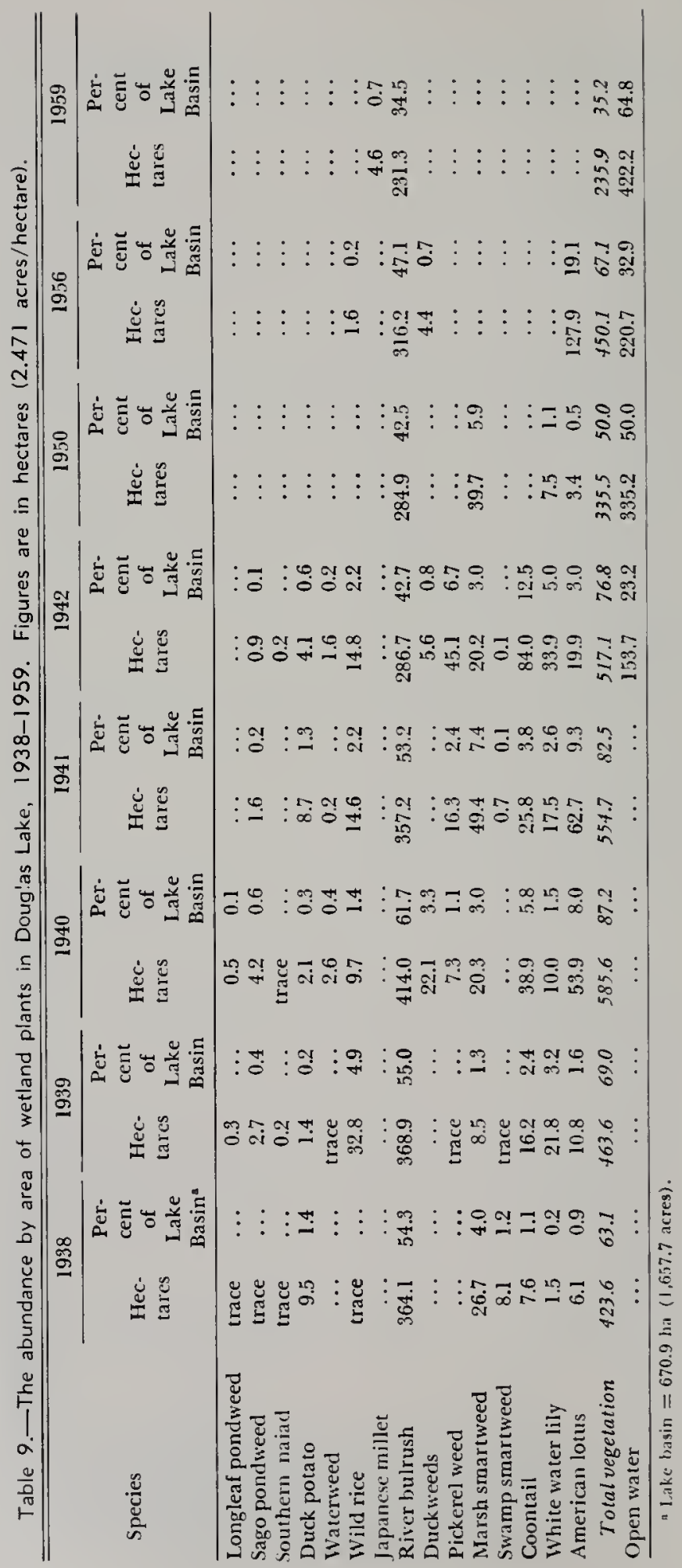


next 2 years the river buIrush area increased slightly, encroaching on the black willow zone as a result of the increased water depth. Then the higher water level began to have an effect; river bulrush declined from 414.0 ha (1,023 acres) in 1940 to 231.3 ha (571.5 acres) in 1959 and 199.1 ha (492 acres) in 1976.

Wave action increased turbidity as the retreat of the river bulrush left an expanding area of open water on the lake. By the 1950's, the several pondweeds and coontail had disappeared (Table 5). Marsh smartweed increased to 7.4 percent of the lake basin in 1941, as it invaded beds of river bulrush, but the increased water depth eventually extirpated it in the early $1950^{\circ}$ s. Wild rice became much reduced in area: only 1.6 ha (4.0 acres) were found in 1956 and none thereafter. Pickerel weed was gone by 1950 and failed to reappear in subsequent years (Table 9). White water lily increased as a result of the greater depth, reaching a peak in 1942 when 5 percent of the lake basin was covered (Table 9). White water lily decreased to only 1.I percent of the basin in 1950 and disappeared thereafter. There was much yearly variation in the abundance of American lotus, but none was found in 1959. 1976, and 1977; only small beds appeared in other years. Apparently the increased wave action and turbidity were responsible for reducing the abundance of both aquatic and marsh plants.

\section{Spring Lake}

Spring Lake is a remnant of a large bottomland lake leveed and drained for agriculture in 1910. Because it was isolated from the Illinois River by a large levee and fed by spring waters, Spring Lake enjoyed highly stable water levels, and it contained extensive beds of aquatic plants in 1938 and 1941 (Table 10). In 1958 the lake level was raised $0.9 \mathrm{~m}$ (3 ft), doubling the lake
Table 10.-The abundance by area of aquatic and marsh plants at Spring Lake, Tazewell County, 1938, 1941, and 1976. Figures are in hectares (2.471 acres/hectare).

\begin{tabular}{lrrr}
\hline \multicolumn{1}{c}{ Species } & 1938 & 1941 & 1976 \\
\hline Sago pondweed & trace & 0.4 & $\ldots$ \\
Longleaf pondweed & 4.0 & $\ldots$ & $\ldots$ \\
Southern naiad & 31.6 & 22.6 & $\ldots$ \\
Duck potato & 10.1 & 6.5 & $\ldots$ \\
Waterweed & 29.1 & 1.8 & $\ldots$ \\
Wild rice & 0.2 & 0.2 & $\ldots$ \\
River bulrush & 12.1 & 5.1 & $\ldots$ \\
Water stargrass & 10.1 & 5.9 & $\ldots$ \\
Coontail & 78.1 & 46.7 & 4.0 \\
American lotus & 8.1 & 6.6 & $\ldots$ \\
$\quad$ Total vegetation & 183.4 & 95.8 & 4.0 \\
\hline
\end{tabular}

area to its current size of 601.0 ha (1,485.1 acres).

The increase in water depth combined with an increase in turbidity to produce such unfavorable conditions that all but a minute portion of the aquatic plants clisappeared (Table 10). Initially, water depths in the principal aquatic beds ranged from 0.6 to $1.5 \mathrm{~m}$ $(2-5 \mathrm{ft})$; Secchi disk transparencies varied from 45.7 to $152.4 \mathrm{~cm} \quad(18-60$ inclies). The increased lake size resulted in greater wave action. Because of the resulting turbidity, aquatics failed to reestablish themselves in the shallow, newly flooded area. The flooded lands were composed of highly organic material that was easily activated by waves. As a result, Secchi clisk transparencies declined from previous readings of $45.7-152.4 \mathrm{~cm}$ by amounts of 30.5 to $40.6 \mathrm{~cm}$ (12-16 inches). Although water depths ranged from 0.5 to $1.2 \mathrm{~m}$ (1.5-4.0 ft) over 60.7 lia (150 acres), turbidity apparently prevented acquatics from developing in the shallow waters. Not only did turbiclity increase as a result of wave action on light soils, but phytoplankton production also increased because of an increase in domestic pollution.

\section{Anderson Lake}

Structures placed at the outlet of Anderson Lake in 1950 helped stabilize 
low-water levels. This stabilization apparently enhanced growing conditions for coontail, for it was noticeably more abundant during 1955-1959 than in 1938-1939 (Table 4). Depths over much of the lake ranged from 50.8 to $101.6 \mathrm{~cm}$ (20-40 inches).

The lake level was raised $0.5 \mathrm{~m}$ ( 1.5 $\mathrm{ft}$ ) in 1958 and an additional $0.5 \mathrm{~m}$ (l.5 ft) in 1964. American lotus disappeared from the lake in 1959 and has been virtually absent since. Coontail began decreasing in abundance in $\mathbf{1 9 5 9}$ and by 1965 had all but disappeared from the lake. Marsh smartweel at first invaded areas vacated by willows as thcy retreated from the higher water level, but ultimately the area in smartweeds began a decrease that continued through the 1960's. By 1976 only fragments of the once extensive marsh smartweed beds remained.

\section{EFFECTS OF TURBIDITY AND SEDIMENTATION}

It is apparent from our studies of wetland vegetation in Illinois Valley lakes that fluctuating water levels, water depth, and turbidity have been the prime physical factors affecting its abundance. However, fluctuating water levels appear less responsible than other factors for the steady reduction in numbers of aquatic plants during the 1960's.

A linear regression of the average weekly water level fluctuations, 15 June-12 October, for five periods (1940-1949, 1950-1959, 1960-1969, 1970-1976, and 1938-1976) shows no significant trend in fluctuating water levels through the summer months (Table 11). Although water levels were generally higher between 1938 and 1976, the variation among years is so irregular that the correlation coefficient is not significant. Moreover, during the critical 1960's, when most of the aquatic plants disappeared from the Illinois Valley, the degree of summer
Table 11.-Linear regression of average weekly water levels by yearly periods at the Havana gauge during 15 June-12 October, 1938-1976 $x=$ years in each period; $y=$ range in average weekly water level fluctua. tions).

\begin{tabular}{ccrc}
\hline \hline Years & Intercept & Slope & \multicolumn{1}{c}{$\boldsymbol{r}$} \\
\hline $1940-1949$ & 16.54 & 1.005 & 0.151 \\
$1950-1959$ & 23.97 & 0.992 & 0.015 \\
$1960-1969$ & 22.49 & -0.904 & 0.233 \\
$1970-1976$ & 30.37 & 1.581 & 0.092 \\
$1938-1976$ & 17.18 & 0.326 & 0.168 \\
\hline
\end{tabular}

fluctuations actually declined (Table 11). Therefore, we conclude that increased turbidity and sedimentation were responsible for the disappearance of most aquatic plants from lakes of the Illinois Valley during the 1960's.

Turbidity results indirectly from sedimentation. A study by Jackson \& Starrett (1959) on the turbidity of Lake Chautauqua pointed out their close relationship. They found that a flocculent false bottom had been deposited over the original firm bottom. Fine silt and clay particles are readily resuspended in the lake's water by wave action and fish movements. Similar increases in wind velocity caused Jackson Turbidity Unit (JTU) readings to increase from 174 to $700 \mathrm{in}$ the spring of 1953. but only from 50 to 78 in the summer of 1953. The much smaller increase in summer turbidities was attributed to dense beds of sago pondweed, which prevented the wind from agitating bottom materials. Activities of bottom-feeding fish, particularly carp, also resuspended bottom sediments, locally increasing the turbidity of Lake Chautauqua. The highly significant correlation between JTU's and water transparency measured by a Secchi disk in waters of the Illinois River valley is shown in Fig. 8.

Stall \& Melsted (1951) had earlier studied the sedimentation at Lake Cliautauqua. They reported that the capacity of the lake had been reduced 18.3 percent by sedimentation in 23.75 years. The average amount of sediment 


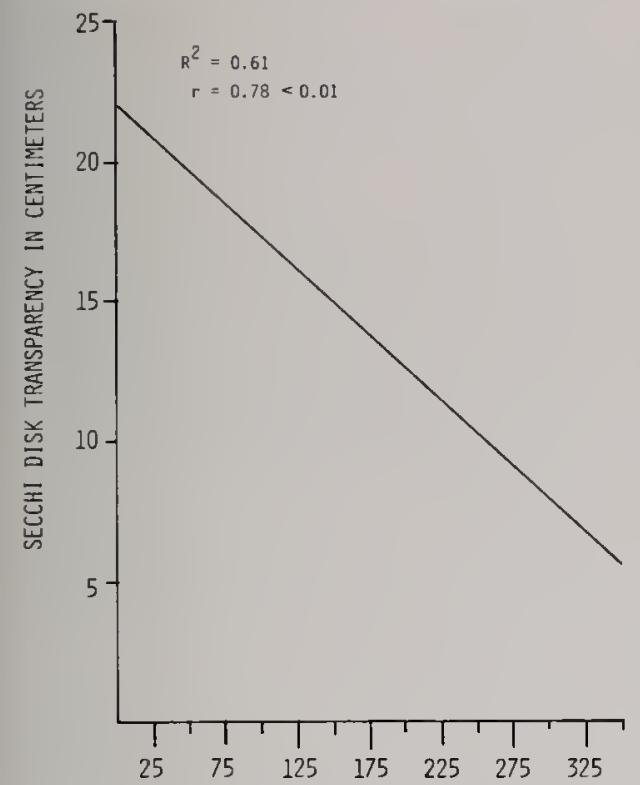

JACKSON TURBIDIMETER UNITS

Fig. 8.-The linear relationship of Jackson Turbidimeter Units and Secchi disk transparency in waters of the Illinois Valley.

deposited annually was 76,414 metric tons ( 84,230 tons). The sediment was brought into Lake. Chautauqua by the Illinois River when it rose above the spillway level or overtopped levees.

Sedimentation in the lllinois river valley is particularly severe for three reasons. (I) Clay and fine silt particles enter the Illinois River as a result of sheet erosion on the intensively farmed Big Prairie region of Illinois, which is drained by numerous tributary streams. (2) The almost colloidal nature of the sediments and the velocity of the tributaries cause much of the sediment load to be transported to the main stem of the Illinois. (3) The sluggish flow of the main channel permits a high percentage of this sediment load to settle in the backwater lakes.

Table 12 shows the JTU readings near the mouths of the Spoon and Mackinaw rivers and in the Illinois River at Havana on 9 August 1977 and in Lake Chautauqua as flood waters entered it on 9 May 1977. The Spoon
Table 12.- The number of Jackson Turbidimeter Units (JTU's) in water samples taken from tributary streams and the main channel of the Illinois River, 9 August 1977. and Lake Chautauqua, 9 May 1977.

\begin{tabular}{|c|c|}
\hline Place & JTU \\
\hline \multicolumn{2}{|l|}{ Mackinaw River } \\
\hline Towerline Road" & 865 \\
\hline Route $29^{\mathrm{n}}$ & 712 \\
\hline Manilo Road" & 987 \\
\hline Spoon River, Route $24^{n}$ & 1,625 \\
\hline Illinois River, IIavana" & 545 \\
\hline \multicolumn{2}{|l|}{ Lake Chaulauqua } \\
\hline $115-600 \mathrm{~m}^{b}$ & 149 \\
\hline $800-1,600 \mathrm{~m}^{\mathrm{c}}$ & 95 \\
\hline \multicolumn{2}{|c|}{$\begin{array}{l}\text { "Three separate measurements of one water sample } \\
\text { averaged. } \\
600 \mathrm{~m} \text { average of five water simples taken at } 115- \\
60 \text { river. } \\
1,600 \mathrm{~m} \text { arom where the river enters the lake. }\end{array}$} \\
\hline
\end{tabular}

and Mackinaw rivers, important tributaries of the Illinois, were bankfull, and waters of the Jllinois River were invading Lake Chautauqua.

The sediment load of the lllinois River was much less than the loads of the Spoon and Mackinaw rivers that enter it near Havana. The waters entering Lake Chautauqua steadily lessened in turbiclity the farther the samples were taken from the point of entry. We interpret these findings as illustrating the loss of sediment load as velocity slackens.

The Mackinaw and Spoon rivers fall at much faster rates than does the Illinois River. The Illinois River drops at the rate of $0.01 \mathrm{~m}$ per $\mathrm{km}(0.04 \mathrm{ft}$ per mile) from Peoria to Beardstown. The Mackinaw River falls at the rate of $0.70 \mathrm{~m}$ per $\mathrm{km}$ (3.7 ft per mile) from the upper sampling site to its mouth; the Spoon River falls at the rate of 0.57 m per $\mathrm{km}$ (3.01 $\mathrm{ft}$ per mile) from the sampling site to its confluence with the Illinois River.

These three factors-soil erosion, the high velocities of tributaries, and the sluggish flow of the main channel-together have brought about an environmental (lisaster: backwater lakes of the Illinois River are filling at a rapid rate leading to their early extinction. 
Fig. 9 shows the sedimentation rates in seven lakes above Peoria. These lakes are lateral to the river channel, except Upper Peoria Lake, through which the river flows. The linear regressions show a high correlation between the depth of the water and the rate of sedimentation. Sedimentation increases as the water deepens because of the greater standing column of water from which sediments precipitate. The exceptionally high correlation coefficients $(r)$ confirm this relationship.

Upper Peoria Lake has a lower sedimentation rate than the other lakes because the river transports more sediment through it than through lateral lakes. At 2.1 in $(7 \mathrm{ft})$, the yearly rate of sedimentation is $0.01 \mathrm{~m}(0.056 \mathrm{ft})$ as compared with $0.024-0.027 \mathrm{~m}(0.078-$ $0.090 \mathrm{ft}$ ) in the other lakes. The lateral lakes are inundated during floods. Reduced current velocity in these lakes allows more sediment to precipitate than can drop out at the higher ve- locities present in Upper Peoria Lake. There is amazingly little difference among the sedimentation rates in lateral lakes above Peoria. Fig. 9 indicates that at a water depth of $0.3 \mathrm{~m}$ (l ft) in Upper Peoria Lake wave and ice action have an erosive effect on the shallow margins of the lake bed and transport bed material to other areas. The same action has affected the shore margins of some of the lateral lakes.

Below Peoria, sedimentation studies were made at Rice Lake, Lake Chautauqua, Anderson Lake, and Meredosia Bay (Fig. 10). These lakes have lower and more diverse sedimentation rates than the upper lakes.

The differences in sedimentation rates among lakes can be accounted for by their relative isolation from the river. The lakes above Peoria have only low, narrow peninsulas of land separating them from the river at levels below flood stage. All of the lateral lakes studied above Peoria have

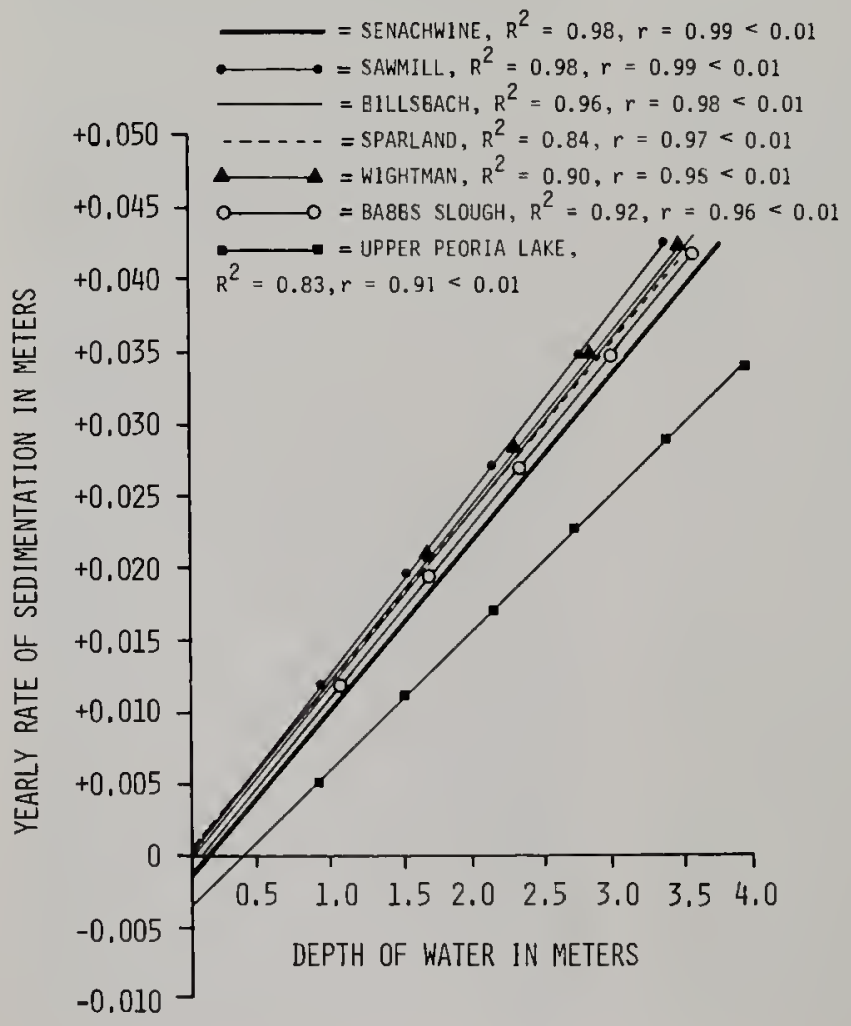

Fig. 9.-Linear relationships between the depth of water and the yearly rate of sedimentation in seven bottomland lakes in the upper Illinois River valley between Hennepin and Peoria. 
Fig. 10.-Linear relationships between the depth of water and the yearly rate of sedimentation in four bottomland lakes in the lower Illinois River valley between Banner and Meredosia.

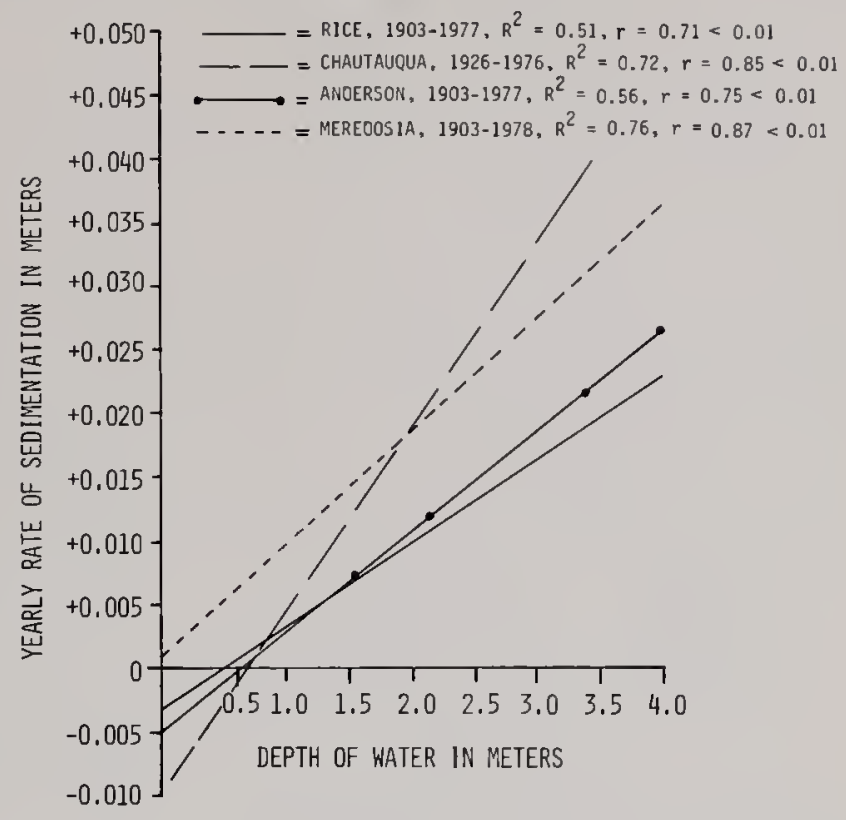

broad inlets-outlets at their lower ends, connecting them to the river at all stages. Hence, they are subject to seclimentation from river waters at all stages above the minimum. The degree of separation of lateral lakes from the river is greater below Peoria, where sedimentation rates among the lakes stuclied are lower and more variable.

In this group. Rice Lake is the most isolated from the river, and it has the lowest seclimentation rate of all lakes studied. Anderson Lake is protected at its upper end by a large agricultural levee and on its river side by a natural levee $1.8 \mathrm{~m}(6 \mathrm{ft}$ ) above normal river level. Mereclosia Bay is partially isolated from the river by an agricultural levee at its upper end and by a broad lateral peninsula of land that permits little ingress of river water until the river has risen $3 \mathrm{~m}$ (10 ft). Although surrounded by levees, Lake Cliautauqua spillway clevations are $133.4 \mathrm{~m}(437.5$

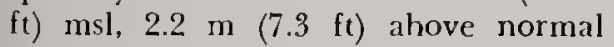
river level. However, water was let into the lake through gates when projected river rises threatened to overtop the spillways; in recent years erosion has reduced the spillway level to 132 in
(433 ft) msl. Once river water enters, it is trapped in Lake Chautauqua to a greater degree than in any natural lake; consecutently, the sedimentation rate is higher than at Rice and Anderson lakes.

Data previously obtained at Upper Peoria Lake, Lake Chautauna, and Meredosia Bay by the U.S. Army Corps of Engineers, the Illinois State Water Survey, and the State Division of Water Resources, and data obtained by us for 1976 and 1978 enabled us to calculate linear regressions for the two groups of years to determine periodic sedimentation rates (Fig. 11, 12, and 13). Seclimentation rates were appreciably higher in the more recent period at all three lakes.

The rise in sedimentation rates in the lllinois River valley in recent years inclicates a pronounced increase in the sediment load of the river. The sediment load appears to lave increased as a result of the intensified growing of row crops on the watershed of the river and an increase in tributary stream bank erosion.

In the early 1900 's, lakes in the Illinois Valley had bottom profiles that 


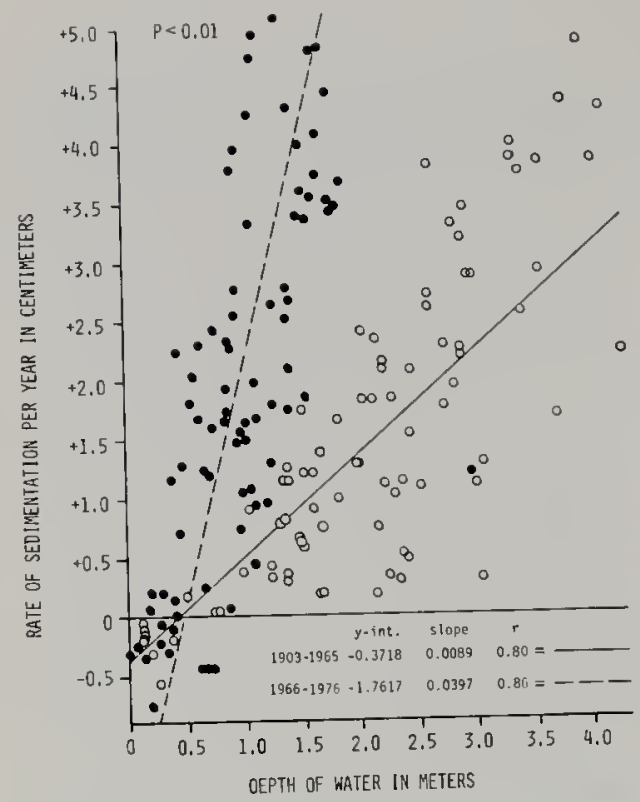

Fig. 11.-The linear relationship between the yearly rate of sedimentation and the depth of water in Upper Peoria Lake in each of two time periods. 1903-1965 and 1966-1976.

$=1926-1950, R^{2}=0.41, r=0.64<0.01$

$=1951-1976, R^{2}=0.50, r=0.71<0.01$

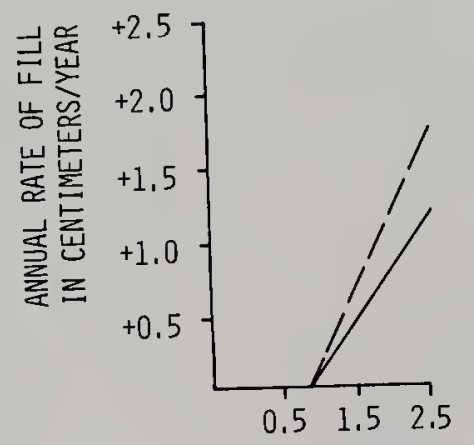

DEPTH IN METERS

Fig. 12.-The linear relationship between the yearly rate of sedimentation and the depth of water in Lake Chautauqua in each of two time periods, 1926-1950 and 1951-1976.

presented a diversity of elevations (Fig. 14 and 15). By the mid-1970's the bottom profiles had flattened into plattershaped basins because of the greater deposition of sediment in the deeper waters. Because seclimentation is dynamic, the amount of silt deposited

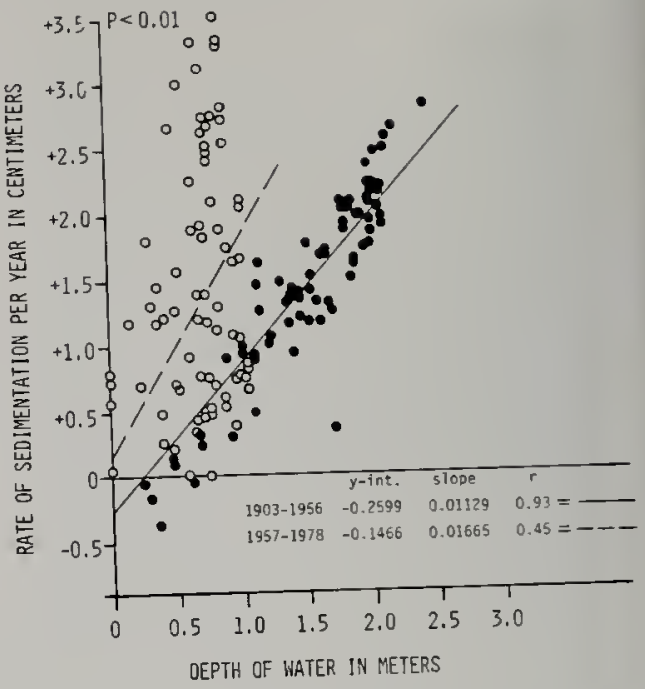

Fig. 13.-The linear relationship between the yearly rate of sedimentation and the depth of water in Meredosia Bay in each of two time periods, 1903-1956 and 1957-1978.

in a backwater lake changes as lake depths change. Other factors (such as the sediment load carried by the river) being equal, the total amount of sediment deposited per year in backwater lakes lessens as the lakes become shallower. Inasmuch as lake beds have different elevations, resulting in different degrees and time spans of inundations, sedimentation rates differ from lake to lake at comparable depths.

Table 13 shows the total amount of sediment deposited in 11 bottomland lakes during this century. The lakes that were originally deepest have received the greatest amounts of sediment. The total fill is staggering, leaving most bottomland lakes with shallow basins that are rapidly being filled as sediments "rain down" from the waters above. Because of its depth, Upper Peoria Lake in all likelihood will be the last lake remaining in the Illinois Valley. Rice Lake probably will fill more slowly than the other lateral lakes as a result of its distance from the river and the relatively high elevation of its basin.

Sawmill, Billsbach, Sparland, Wightman, Babbs Slougl, and many other 
Aug. 1979 Bellorose et Al.: Waterfowl and the Changing Illinois Valley

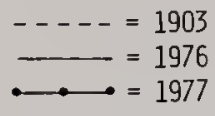

WIGHTMAN LAKE

TRANSECT A

RIVER MILE 188.2

WATER SURFACE $=440.05 \mathrm{~ms} 1$

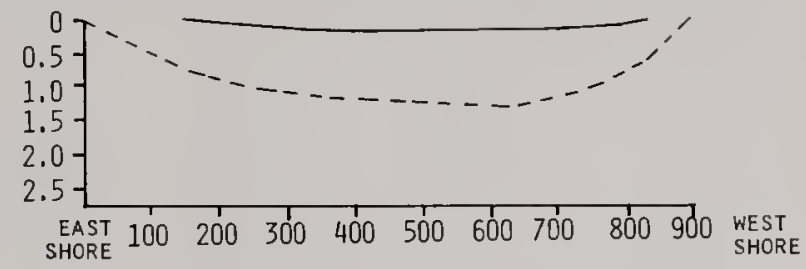

METERS

rig. 14.-A cross section of each of three lakesWightman, Babbs Slough, and Rice-delineating the bottom contours in 1903 and in 1976 or 1977.
Fig. 15.-A cross section of Senachwine Lake, showing its bed in 1903 and 1976, and a cross section of Upper Peoria Lake, showing bottom elevations in 1903, 1965, and 1976. The deep trench in Upper Peoria Lake is the channel of the river. At Senachwine and other bottomland lakes, the river channel is lateral to their basins.
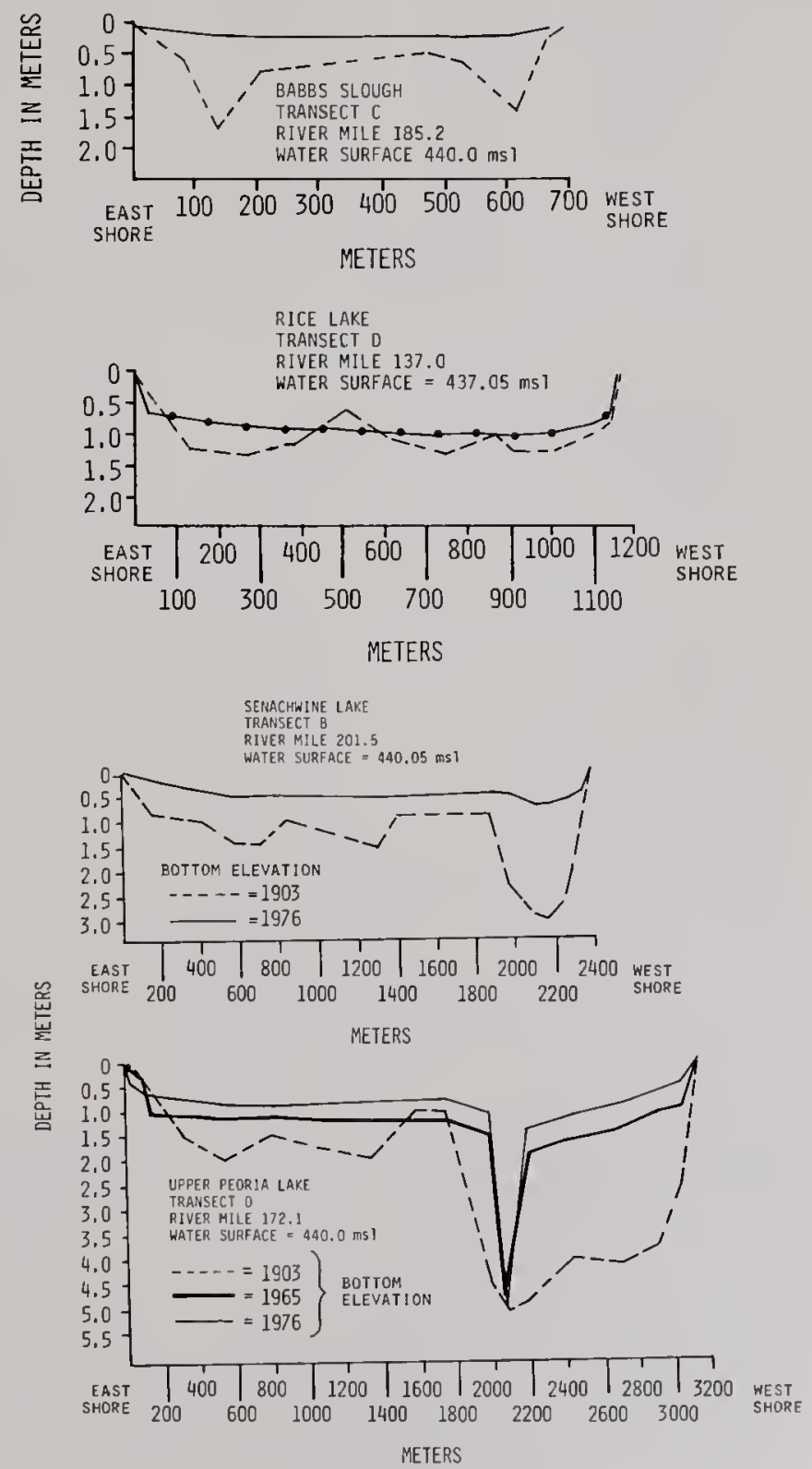
Table 13.- The total sedimentation, annual sedimentation, and average water depth in 1976 of 11 bottomland lakes in the Illinois River valley. Sediments and depths are recorded in centimeters at normal water levels.

\begin{tabular}{|c|c|c|c|c|c|}
\hline Lake & $\begin{array}{c}\text { Span of } \\
\text { Measurement } \\
\text { of Sed- } \\
\text { imenlalion } \\
\text { in Years }\end{array}$ & $\begin{array}{c}\text { Lake } \\
\text { Surface } \\
\text { Elevalion } \\
\text { msl in } \\
\text { meters }\end{array}$ & $\begin{array}{c}\text { Total } \\
\text { Sedimen- } \\
\text { lation' in } \\
\text { Cenlimeters }\end{array}$ & $\begin{array}{l}\text { Average } \\
\text { Sedimen- } \\
\text { tation } \\
\text { Per Year } \\
\text { in Centi- } \\
\text { meters }\end{array}$ & $\begin{array}{c}1976 \\
\text { Average } \\
\text { Water } \\
\text { Depth } \\
\text { in Centi- } \\
\text { meters }\end{array}$ \\
\hline Senachwine & 72 & 134.1 & 107.5 & 1.5 & 31.1 \\
\hline Sawmill & 72 & 134.1 & 107.5 & 1.5 & 8.2 \\
\hline Billsbach & 72 & 134.1 & 94.2 & 1.3 & 17.1 \\
\hline Sparland & 72 & 134.1 & 84.3 & 1.2 & 12.5 \\
\hline Wightman & 72 & 134.1 & 103.8 & 1.4 & 10.1 \\
\hline Babbs Slough & 72 & 194.1 & 32.9 & 0.5 & 11.0 \\
\hline Upper Peoria & 72 & 134.1 & 121.1 & 1.7 & 108.5 \\
\hline Rice & 74 & 133.2 & 19.0 & 0.2 & 70.7 \\
\hline Chautauqua & 50 & 132.6 & 43.2 & 0.9 & $79.9^{e}$ \\
\hline Anderson & 74 & 132.4 & 30.6 & 0.4 & 81.7 \\
\hline Meredosia & 75 & 129.3 & 97.4 & 1.3 & 88.4 \\
\hline
\end{tabular}

a Fill and water depth calculations are based upon surface elevation in meters msl.

b Average sediment accumulations are based upon differences in depth soundings taken at each lake in two periods.

From Lee (1976 unpublished).

lakes above Peoria evidently have short remaining lives (Table 13 ).

Lee \& Stall (1976 unpublished) reported on the sedimentation of Lake Depue, a lake lateral to the Illinois River above Peoria. They projected that in 33 years the lake would fill with sediment to $134.4 \mathrm{~m} \mathrm{(441} \mathrm{ft)} \mathrm{msl,} \mathrm{the}$ current normal lake surface elevation. They determined that the average lake depth in 1975 was $49.3 \mathrm{~cm}$ (19.4 inches).

The projected life of Lake Chautauqua, according to Lee (1976 unpublished), is 92 years, based upon the ratio of average depth to the current annual rate of rise in the lake bed. A sediment survey of Meredosia Bay by Lee et al. (1976 unpublished) led to the conclusion that its expected life is 90 years.

It is apparent that although total sediment deposits theoretically lessen as bottomland lakes become shallower, the yearly sedimentation rate per centimeter of water depth has actually increased. The intensive growing of row crops on Illinois River watershed lands has resulted in widespread sheet erosion. Unless a change occurs in land management practices, the years of life remaining to Illinois Valley lakes are numbered.

Between 1945 and 1976, row cropland in the Illinois River basin increased from $3,496,487$ to $5,231,031$ ha (8,639,700-12,925,700 acres), up 66.8 percent. In the entire state, row cropland rose from $4,811,883$ ha $(11,890,000$ acres) in 1945 to $7,911,885$ ha $(19,550$,000 acres) in 1976, an increase of 60.8 percent (Illinois Cooperative Crop Reporting Service 1968 and 1977). Most of the additional row crop area was devoted to growing soybeans. All row crops expose soils to more sheet erosion than do other kinds of crops, but soybeans provide even less protection to the land than corn provides.

\section{EFFECTS OF FOOD RESOURCES ON FALL WATERFOWL POPULATIONS}

For 40 years, Bellrose has observed that the availability of food is the most important factor affecting the abundance and distribution of waterfowl in the Illinois Valley. Yet, there are other 
variables affecting the local abundance of waterfowl. Moreover, as will be discussed, a regression analysis of the annual availability of natural food resources is difficult.

It is almost impossible to quantify seed yield, palatability, and availability of waterfowl food plants. A study of seed and vegetative yield by Low \& Bellrose (1944) illustrated a wide diver. sity among species of wetland plants. The yield of any one species may vary from year to year, depending upon the growing period and competition from weed species. Fall floods may make seeds and other vegetative parts unavailable to dabbling clucks. Seeds produced in one year by moist-soil plants may still be available in bottom soils in the following year for ducks to feed upon at times when current moist-soil plant development is at a minimum. Mallards obtain a large proportion of their food from the waste corn left after harvest (Anclerson 1959) and are, therefore, only partially influenced by the availability of naturally occurring foods. Many diving ducks, especially the lesser scaup, are influenced more by the availability of animal than plant food. Local duck populations are also influenced by yearly fluctuations in the continental and flyway populations of the various species.

These complex variables, combined with the failure of vegetation maps aclequately to sample waterfowl food plant availability, make it difficult to compare the abundance of wetland plants with that of waterfowl. Nevertheless, we have found a relationship between the abundance of wetland plants and the abundance of some species of waterfowl in the Illinois Valley.

Fig. 16 shows a significant correlation between the abundance of moist-soil and marsh plants and the number of pintails. Anclerson's (1959) study of the food preferences of the pintail in the Illinois Valley pointed up the primary importance of the seeds of moist-soil

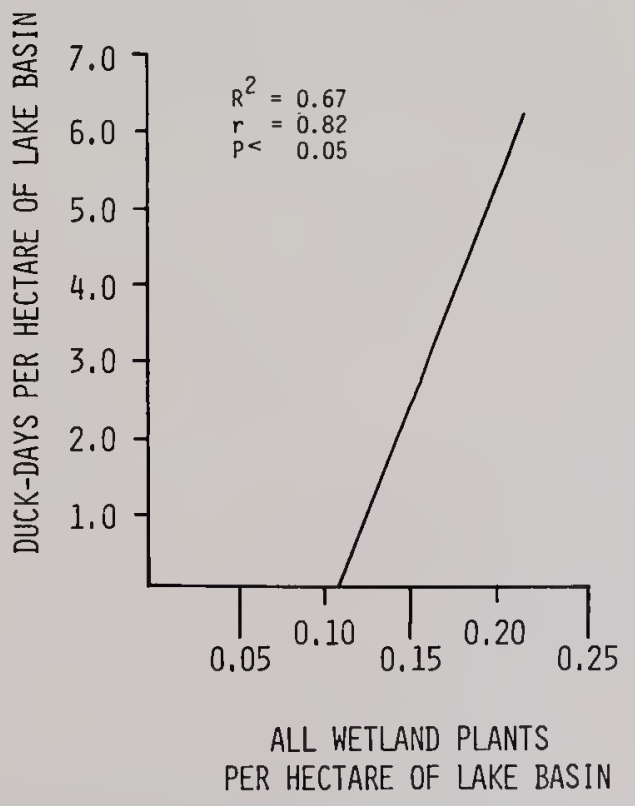

Fig. 17. - The linear relationship between the yearly abundance of American greenwinged teals and that of all wetland plants in the Illinois River valley.
Fig. 16. - The linear relationship between the yearly abundance of pintails and the yearly abundance of moist-soil and marsh vegetation in the Illinois River valley.

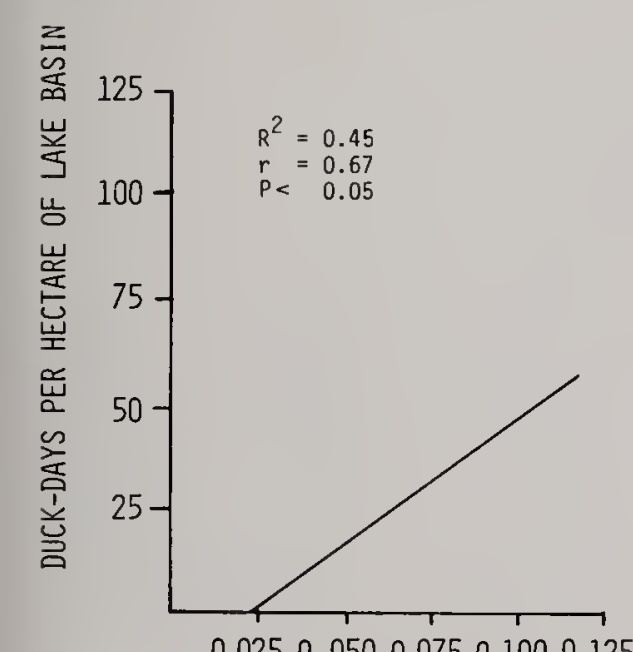

\section{MOIST-SOIL AND MARSH PLANTS} PER HECTARE OF LAKE BASIN

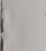


plants and the secondary importance of marsh plants in the diet of this species.

Green-winged teal numbers were influenced by the relative abundance of all wetland plants (Fig. 17) rather than

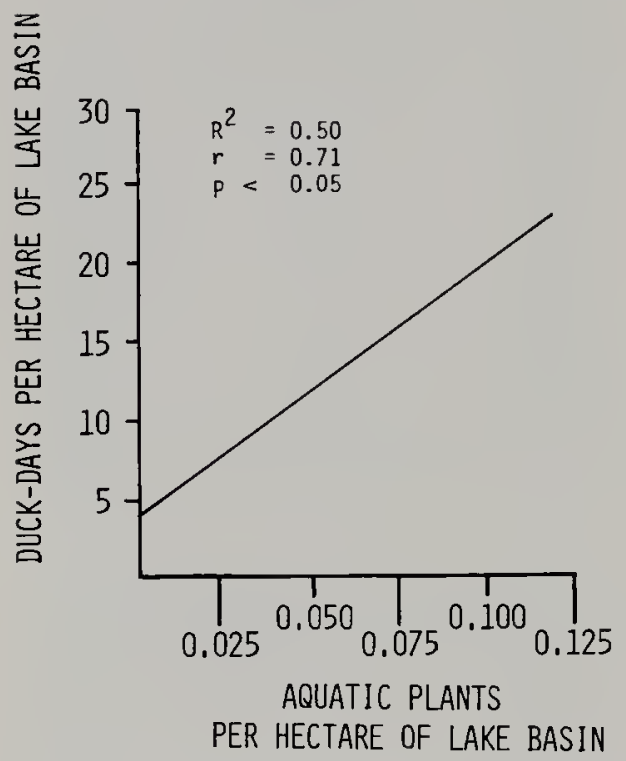

Fig. 18.-The linear relationship between the yearly abundance of American wigeons and that of aquatic plants in the Illinois River valley.

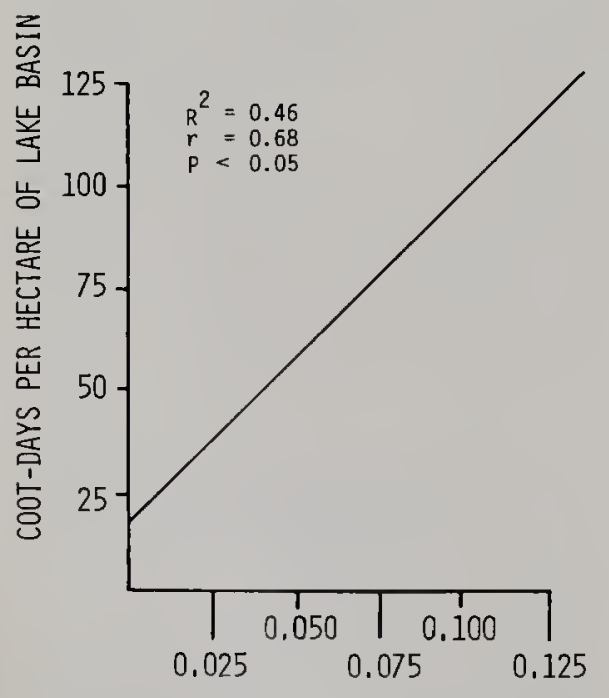

AQUATIC PLANTS/HECTARE OF LAKE BASIN

Fig. 19. - The linear relationship between the yearly abundance of coots and that of aquatic plants in the Illinois River valley. by that of any particular plant group. Yet a food-preferences study of these ducks by Anderson (1959) revealed their preference for seeds of moist-soil plants.

As might be expected, wigeon and coot populations were significantly correlated with the yearly abundance of aquatic plants (Fig. 18 and 19). Foodpreference studies by Anderson (1959) revealed the importance of the foliage of coontail, sago pondweed, and other aquatics in the diets of these species.

As sago pondweed, southern naiad, and coontail became more abundant in the micl-1960's at Swan, Gilbert, and adjacent lakes above Grafton, so did wigeon and coot populations (Fig. 20). The high water levels of 1965-1968

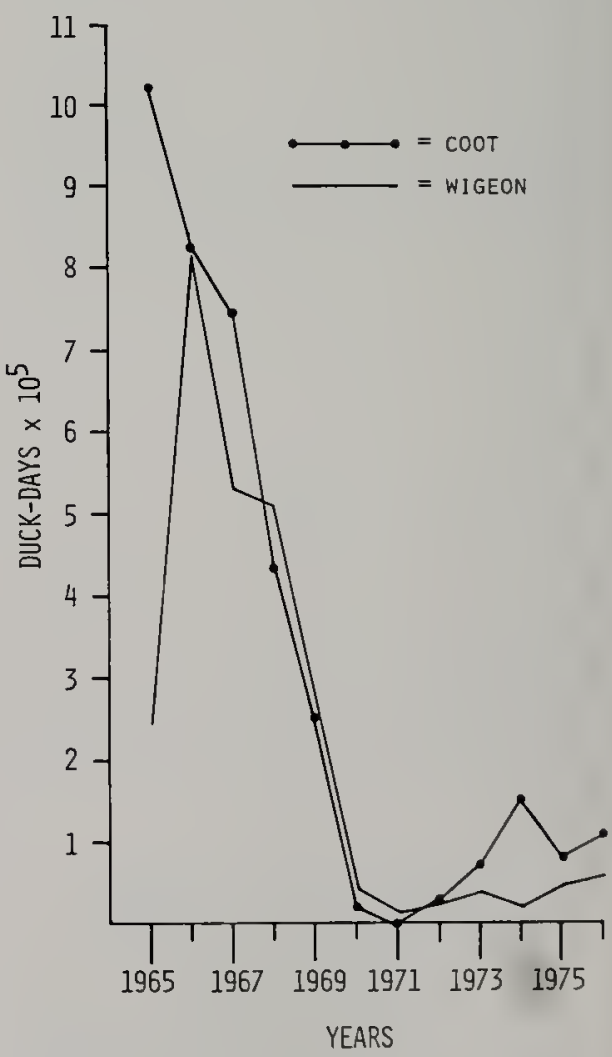

Fig. 20.-The yearly changes in coot and wigeon abundance on Gilbert and Swan lakes, Calhoun Unit of the Mark Twain National Wildlife Refuge, near Grafton, Illinois. The crash in numbers was associated with the disappearance of submerged aquatic plants. 
resulted in the eradication of aquatic plants by 1969 (as previously described) and the consequent collapse of wigeon and coot populations. Aquatic plants had not recovered by 1976 and neither had the local wigeon and coot populations (Fig. 20).

\section{SUMMER WATER LEVELS AND FALL WATERFOWL ABUNDANCE}

We have previously shown the correlation between summer water levels and wetland plants and that between wetland plants and the fall abundance of certain species of waterfowl. However, our most precise and extensive data are on waterfowl abundance and water levels. Our evaluation of these factors is made on the assumption that summer water levels, used to calculate the Moist-Soil Water-Level Index, govern the growth of moist-soil food plants and that they in turn affect the abundance of fall waterfowl.

Fig. 21 dlemonstrates that the fall populations of several species of dab- bling ducks are reflected in the MoistSoil Water-Level Index. In the upper Illinois Valley, above Peoria, only the pintail showed a significant correlation between the Moist-Soil Water-Level Index and subsequent fall abundance. However, four species of dabbling ducks in the lower Illinois Valley (below Peoria) had significant correlations between fall population levels and the Moist-Soil Water-Level Index (Fig. 2I).

The slopes of the linear regressions inclicate that pintail numbers responded the most dramatically when a high Moist-Soil Water-Level Index occurred. (The higher the index, the longer the duration of low water.) Wigeon and green-winged teal populations responded less to these conditions, and fall blue-winged teal numbers responded only slightly to a high Moist-Soil Water-Level Index.

Fall populations of the mallard, the most abundant cluck in the Illinois Valley, did not show a significant correlation with the Moist-Soil WaterLevel Index for two reasons:
Fig. 21.--Linear relationships between the abundance of four species of dabbling ducks during the fall and the Moist-Soil Water-Level Index in the Illinois Valley. Upper refers to the upper Illinois River above Peoria, and lower refers to the river below Peoria.
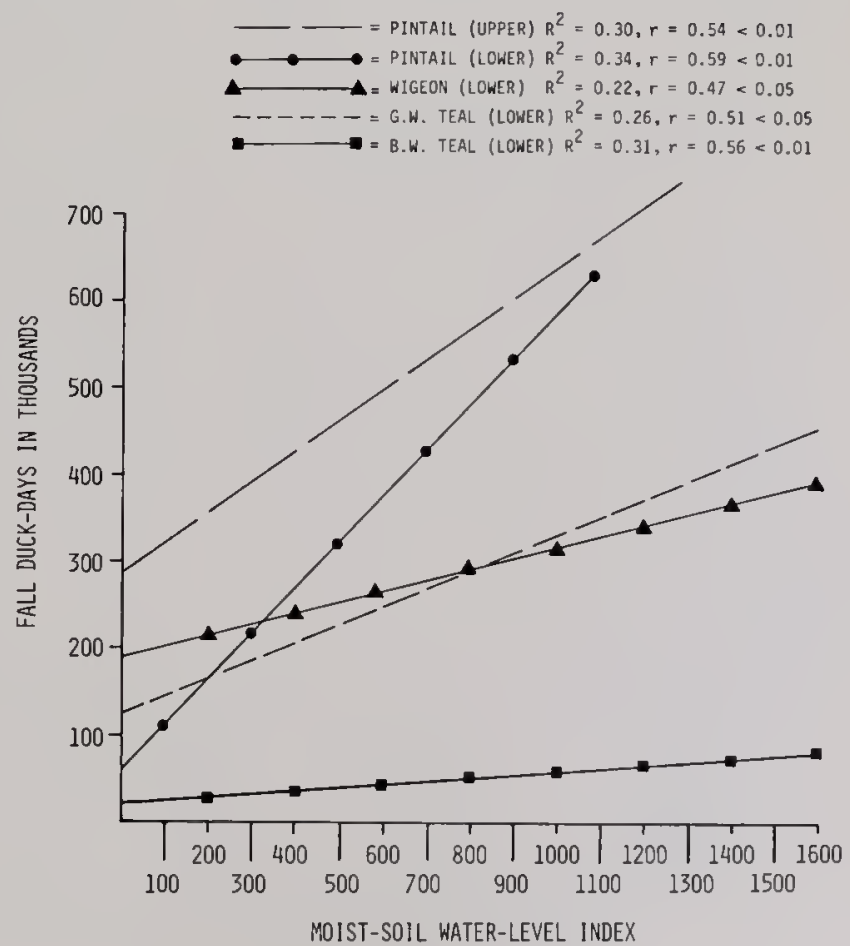
changes in the continental abundance of mallards from year to year masked local population changes, and (2) the mallard obtains much of $i$ ts food from waste grain in harvested corn fields and is, therefore, more independent of naturally occurring food resources than are other ducks.

We employed a multiple regression equation $\left(z=a_{0}+a_{1} x+a_{2} y\right)$ that incorporated the yearly continental mallard population as an independent variable, the Moist-Soil Water-Level Index as an independent variable, and mallard duck-day use as the dependent variable. Fig. 22 and 23 demonstrate that when these variables are evaluated, the Moist-Soil Water-Level In- dex also influenced mallard populations in the Illinois Valley.

The coefficient of determination $\left(\mathrm{R}^{2}\right)$ suggests that slightly over half of the yearly variation in mallard numbers in the Illinois Valley is accounted for by variations in the size of the continental population and the Moist-Soil WaterLevel Index. The spread among the several Moist-Soil Water-Level Indices points up the effects that they have on mallard numbers in the upper and lower Illinois Valley. As with other dabbling ducks, the Moist-Soil WaterLevel Index illustrates the influence of summer water levels on populations of mallards more in the valley below Peoria than above.
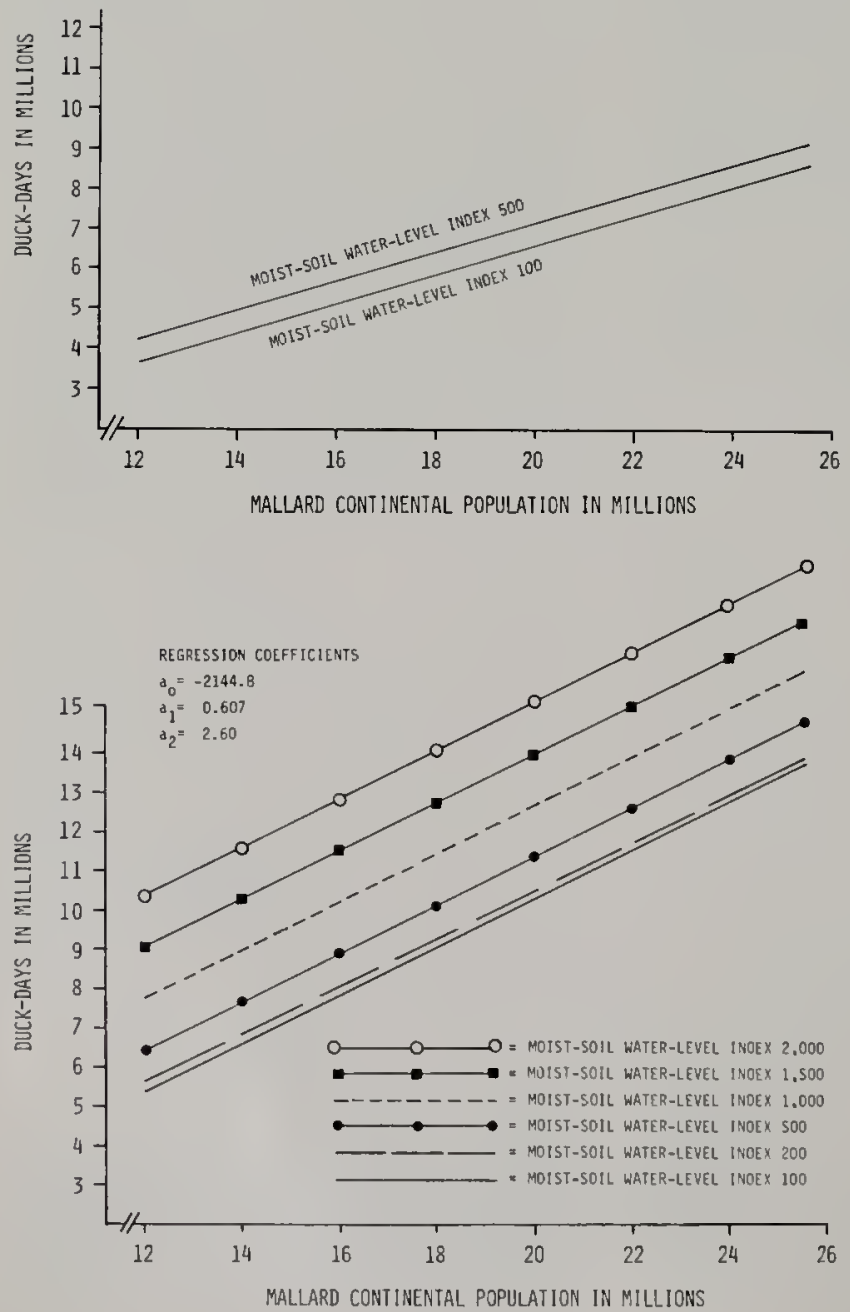

Fig. 22.-Multiple regression analysis of mallard abundance in the upper IIlinois Valley in comparison with mallard continental abundance and the MoistSoil Water-Level Index in the upper Illinois Valley.

Fig. 23.-Multiple regression analysis of mallard abundance in the lower 11 linois Valley in comparison with mallard continental abundance and the MoistSoil Water-Level Index in the lower Illinois Valley. 
We pointed out earlier that a high Moist-Soil Water-Level Index reflects more extensive mud flats and hence more moist-soil plant food resources in the lower valley. Therefore, it is not surprising that dabbling ducks respond more to low water levels in the lower than in the upper Illinois Valley.

We found no significant correlation between the Moist-Soil WaterLevel ludex and the abumdance of diving clucks in the Illinois Valley. Stuclies of the food preferences of the several species of divers--Iesser scaup, canvasback, ring-necked duck, and rucldy cluck-by Anderson (1959) rercaled that in the Illinois Valley they feed primarily on animal life. The effect of change in the abundance of a staple animal food item on diving duck abundance will be discussed later.

\section{FALL WATER LEVELS}

In the flat-basined lakes of the Illinois River valley, slight rises in fall water levels are alvantageous in inundating moist-soil plant beds so that their seeds can be used by ducks. However, if the river rises too high, the moist-soil plant beds are covered too deeply for dabbling ducks to use their seed resources effectively. On the other hand, when waters remain low during the fall, tens of thousands of ducks can be observed feeding on mud flats and in shallow water early in the season. Examination of soil samples from these habitats reveals little animal life but multitudes of seeds of moist-soil plants that have been deposited in carlier years. It is assumed, therefore, that previous crops of moistsoil plant seeds are being consumed.

It was within this context that we analyzed the effect of fall water levels on fall populations of dabbling ducks in the lower lllinois Valley. Water levels were averaged yearly from 1949 to 1976 for the period 1 October-1 December, using the Havana gauge readings. These average fall water levels were compared, using a regression analysis, to the yearly fall waterfowl populations of several dabbling duck species (Tab!c 14). The coefficient of determination $\left(R^{2}\right)$ implies that fall water levels accounted for about 16 percent of the yearly variation in fall populations of mallards and greenwinged teals, and for 6-8 percent of such variation in the abundance of pintails, blue-winged teals, and wigeon. In all these species (slope column, Table 14) the numbers of dabbling ducks decline when water levels rise above normal during the fall. Normal water level is considered to be at the tree line, and feeding conditions become unfavorable for dabbling clucks when this level is exceeded.

\section{WATER LEVELS IN RELATION TO THE DURATION OF STAY OF DUCKS}

The length of time a duck pauses in fall migration in the Illinois Valley is dependent upon several factors: (1) weather conclitions, (2) shooting pressure and other disturbances, and (3) availability of food. Here we discuss only the availability of food-as re-

Table 14.- Average fall water levels" each year in relation to fall abundance of dabbling ducks in the lower Illinois Valley, 1949-1976.

\begin{tabular}{lccrr}
\hline \multicolumn{1}{c}{ Species } & $\mathrm{R}^{2}$ & $r^{\mathrm{b}}$ & Slope & \multicolumn{1}{c}{$\mathrm{y}$-Intercept } \\
\hline Mallard & $\mathbf{0 . 1 6}$ & 0.40 & $-890,096$ & $\mathbf{1 8 , 9 6 0 , 0 0 0}$ \\
Pintail & 0.06 & 0.24 & $-49,143$ & 960,550 \\
Grcen-winged teal & 0.16 & 0.40 & $-47,412$ & 619,770 \\
Blue-winged teal & 0.08 & 0.29 & $-6,284$ & 96,290 \\
Wigeon & 0.07 & 0.26 & $-21,790$ & 457,200 \\
\hline
\end{tabular}

The higher the average fall water level, the lower the fall abundance of dabbling ducks.

r significant at $0.37,<0.05$; and $0.25,<0.10$. 
flected by summer and fall water levels-in relation to the duration of stay of ducks.

A comparison of the peak weekly number of ducks observed with the number of duck-dlays each fall, 19491976 (Table 15), shows how long each particular population inhabits the Illinois Valley. The ratio of the mean peak number of ducks to the mean number of duck-days varies from 13.3 to 27.8 among different species and time periods (Table 15). In most instances the ratio of means varies between 19.6 (for the wigeon) and 22.5 (for the mallard). The implication is that during the fall season the number of duck-dlays equals about 21 times the number of ducks present at the peak of migration. Theoretically, if there were but one flight in and out of the valley, similar maximum numbers would occur over a 21-day period. However, because there are numerous nights of ducks arriving at and departing from the valley, the result is a period of increase followed by a period of decline. The clironology of fall duck populations assumes the shape of a bell curve (Bellrose 1944). Omitting the tails of the curve, the base roughly embraces the following number of days for these species: mallard 60 , pintail 55, green-winged teal 60, wigeon 50 . lesser scaup 55, ring-necked duck 55 . and canvasback 55 (Bellrose, unpublished data).

An earlier analy'sis of mallard recovery data from bandings in the Jllinois Valley led to the conclusion that fall migrants remain for 16-28 days, depending upon which of several sources of data was deemed the most reliable (Bellrose \& Crompton 1970). On the basis of the earlier band recovery study, we interpret the 22.5 ratio of means for mallards (Table 15) as reflecting the average length of time migrating ducks remain during the fall in the lllinois Valley. Henceforth we refer to this ratio of mean peak number of ducks to mean duck-clays in the fall as the Duration of Stay Index.

We surmised that between 1949 and 1976 almost all of the migrating rlucks listed in Table 15 inhabited the Illi. nois Valley for similar periorls of time. centering on 21 days. As shown by the standard deviation and range, the Duration of Stay Index varied by year. The variation among the years is least for the mallard and progressively higher for the green-winged teal, pintail, and wigeon.

We believe that some part of the yearly variation in the Duration of Stay Index results from the changing availability of native fool resources. lieyond affecting peak numbers, food availability undoubtedly also influences

Table 15.-A comparison of the mean peak number of ducks recorded each year with the mean number of duck-days in the fall, 1949-1976.

\begin{tabular}{|c|c|c|c|c|c|c|}
\hline \multirow[b]{2}{*}{ Species } & \multirow{2}{*}{$\begin{array}{c}\text { Mean Peak } \\
\text { Number } \\
\text { of Ducks }\end{array}$} & \multirow{2}{*}{$\begin{array}{l}\text { Nean Number } \\
\text { of Duck-Days }\end{array}$} & \multicolumn{3}{|c|}{ Ratio } & \multirow[b]{2}{*}{$r$} \\
\hline & & & Mean & $\begin{array}{l}\text { Standard } \\
\text { Deviation }\end{array}$ & $\begin{array}{l}\text { Ycarly } \\
\text { Range }\end{array}$ & \\
\hline Mallard & 828,170 & $18,655,000$ & 22.5 & 3.84 & $16.3-30.5$ & 0.93 \\
\hline Pintail & 34,460 & 739,800 & 21.5 & 6.57 & $8.2-36.3$ & 0.93 \\
\hline Green-winged teal & 14,000 & 389,460 & 27.8 & 5.37 & $13.5-40.3$ & 0.96 \\
\hline Wigeon & 20,170 & 395,000 & 19.6 & 9.08 & $13.5-54.8$ & 0.80 \\
\hline \multicolumn{7}{|l|}{ Lesser Scaupa } \\
\hline $1949-1955$ & 326,800 & $6,231,700$ & 19.9 & 5.54 & $14.0-27.9$ & 0.94 \\
\hline $1956-1976$ & 17,980 & 208,150 & 13.3 & 4.78 & $7.2-24.9$ & 0.88 \\
\hline \multicolumn{7}{|l|}{ Canvasback" } \\
\hline $1949-1955$ & 66,900 & $1,268,000$ & 19.8 & 4.68 & $12.5-24.2$ & 0.93 \\
\hline $1956-1976$ & 1,360 & 25,100 & 18.1 & 7.08 & $7.3-30.2$ & 0.78 \\
\hline
\end{tabular}

- Because of a crash in population Jevels heween 1954 and 1956, the analysis is brohen down into two periods: $1949-1955$ and $1956-1976$. 
the duration of time that a given segment of a duck population spends in the valley. As previously discussed, summer water levels determine the development of moist-soil duck food, and fall water levels determine their availability.

Multiple regression coefficients (Table 16) compare increases in summer water levels as expressed by a decrease in the Moist-Soil Water-Level Index and increases in fall water levels (independent variables) with the Duration of Stay Index (dependent variable) for four species of dabbling ducks. The coefficient of determination $\left(\mathrm{R}^{2}\right)$ implies that rising summer and fall water levels had the greatest adverse effect on the green-winged teal, with progressively lessening infuence on pintails, wigeons, and mallards.

The regression coefficients, MoistSoil Water-Level Index $\left(\mathrm{a}_{1}\right)$ and yearly average fall water levels $\left(a_{2}\right)$, inply that rises in summer water levels were more adverse than rises in fall water levels for the duration of stay by mallards and green-winged teals. But high fall water levels had the greater adverse effect on the pintail and wigeon Duration of Stay Indices.

Because of its small size and short neck, we would expect that the greenwinged teal among dabbling ducks wou!d have the greatest difficulty in feeding when water levels are high. Low summer water levels are needed either to produce the seeds of moist-

Table 16.-Multiple regression coefficients of the Duration of Stay Index in relation to summer and fall water levels in the Illinois Valley, 1949-1976.

\begin{tabular}{lrrrr}
\hline \hline \multicolumn{1}{c}{ Species } & $\mathrm{a}_{0}{ }^{\mathrm{a}}$ & $\mathrm{a}_{1}{ }^{\mathrm{b}}$ & $\mathrm{a}_{2}{ }^{\mathrm{c}}$ & $\mathrm{R}^{2 \mathrm{~d}}$ \\
\hline Mallard & 28.2 & -0.52 & -0.11 & 0.07 \\
Pinlail & 33.5 & -0.12 & -1.24 & 0.19 \\
Green- & & & & \\
$\quad$ winged & & & & \\
$\quad$ leal & 38.2 & -1.13 & -0.45 & 0.24 \\
Wigeon & 12.8 & 2.26 & -1.38 & 0.11 \\
\hline
\end{tabular}

" Point of intercept.

- Slope of summer water level.

c Slope of fall water level

d Coefficient of determination soil plants or to make available mud flats that the teal gleans for previous seed crops. Pintails also feed upon mud flats in late summer and fall, but flooding in late summer is not as adverse for them as it is for the shorter necked green-winged teal. However, for unknown reasons, high fall water levels have a greater adverse effect upon the length of stay by pintails. High summer levels favor the wigeon, perhaps through the greater production of filamentous algae. Mallards, as expected, are more independent of water levels than are other dabblers because of their ability to obtain a large part of their food from waste corn left in harvested fields.

Diving ducks are largely independent of fall water levels, because large numbers of lesser scaup and canvasbacks feed on animal life and are independent of moist-soil plant resources. However, a catastrophic loss of fingernail clams, their basic food in the Illinois Valley, during the mid-1950's (Mills et al. 1966) resulted in a dramatic decline in both peak numbers and duck-days (Table 15). The lower Duration of Stay Index, 1956-1976, when fingernail clams have been virtually nonexistent in the valley, points out that not only did the Illinois Valley fail to attract large populations of scaup and canvasbacks, but a]so those that stopped in migration remained more brielly than they formerly did.

The highly significant correlation coefficients $(r)$ between mean peak numbers of ducks and mean numbers of duck-lays (Table 15) implies that either expression adequately reflects yearly clanges in the population status of ducks in the Illinois Valley. It also implies that shortly after arriving ducks detect the availability of food. If litthe food is available, they tarry but a day or wo before continuing in migration. Many field observations by Bellrose on the behavior of migrating waterfowl support this contention. It is 
becoming more prevalent for large numbers of waterfowl that arrive one night to leave the following night because of food shortages.

\section{MANAGEMENT PRACTICES AND CONSIDERATIONS}

The prohibition of baiting in the mid-1930's greatly reduced the duck

Table 17.-Duck clubs in the lllinois River valley. Area figures are in hectares $(2.47)$ acres/hectare).

\begin{tabular}{|c|c|c|c|c|c|c|}
\hline \multirow[b]{2}{*}{ County } & \multirow[b]{2}{*}{$\begin{array}{c}\text { Number } \\
\text { of } \\
\text { Clubs }\end{array}$} & \multirow{2}{*}{$\begin{array}{l}\text { Total } \\
\text { Area } \\
\text { of } \\
\text { Clubs }\end{array}$} & \multicolumn{4}{|c|}{ Clubs Reporting on Water Managemen I } \\
\hline & & & Number & Area & $\begin{array}{c}\text { Area } \\
\text { Under } \\
\text { Conirol }\end{array}$ & $\begin{array}{c}\text { Percent } \\
\text { Under } \\
\text { Control }\end{array}$ \\
\hline La Salle & 18 & $1,035.6$ & 9 & 784.3 & 140.8 & 18.0 \\
\hline Bureau & 30 & $1,233.5$ & 10 & 580.7 & 138.0 & 23.8 \\
\hline Putnam & 29 & $3,055.8$ & 18 & $2,346.7$ & $1,437.5$ & 61.3 \\
\hline Marshall & 38 & $3,414.0$ & 22 & $3,040.9$ & 444.8 & 14.6 \\
\hline Woodford & 26 & $1,649.9$ & 17 & $1,217.3$ & 341.2 & 28.0 \\
\hline Peoria & 6 & 739.8 & 5 & 711.0 & 342.0 & 48.1 \\
\hline Tazewell & 1 & 47.8 & I & 47.8 & 11.3 & 23.6 \\
\hline Fulton & 7 & 620.8 & 4 & 216.5 & 141.6 & 65.4 \\
\hline Mason & 62 & $8,663.7$ & 38 & $7,182.9$ & $2,907.7$ & 40.5 \\
\hline Schuyler & 2 & 502.7 & 2 & 501.8 & 170.0 & 33.9 \\
\hline Cass & 21 & $2,536.0$ & 18 & $2,525.3$ & 381.6 & 15.1 \\
\hline Brown & 1 & 85.0 & 1 & 85.0 & 72.8 & 85.6 \\
\hline Morgan & 3 & 350.5 & 2 & 315.7 & 6.1 & 1.9 \\
\hline Pike & 1 & 35.2 & 1 & 35.2 & 35.2 & 100.0 \\
\hline Scott & 2 & 15.0 & $\ldots$ & $\ddot{0}$ & $\cdots$ & 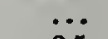 \\
\hline Greene & 4 & 599.0 & 2 & 80.9 & 2.0 & 2.5 \\
\hline Calhoun & 1 & 52.2 & 1 & 52.2 & 9.7 & 18.6 \\
\hline Total & 252 & $24,636.5$ & 151 & $19,724.2$ & 6,5823 & 33.4 \\
\hline
\end{tabular}

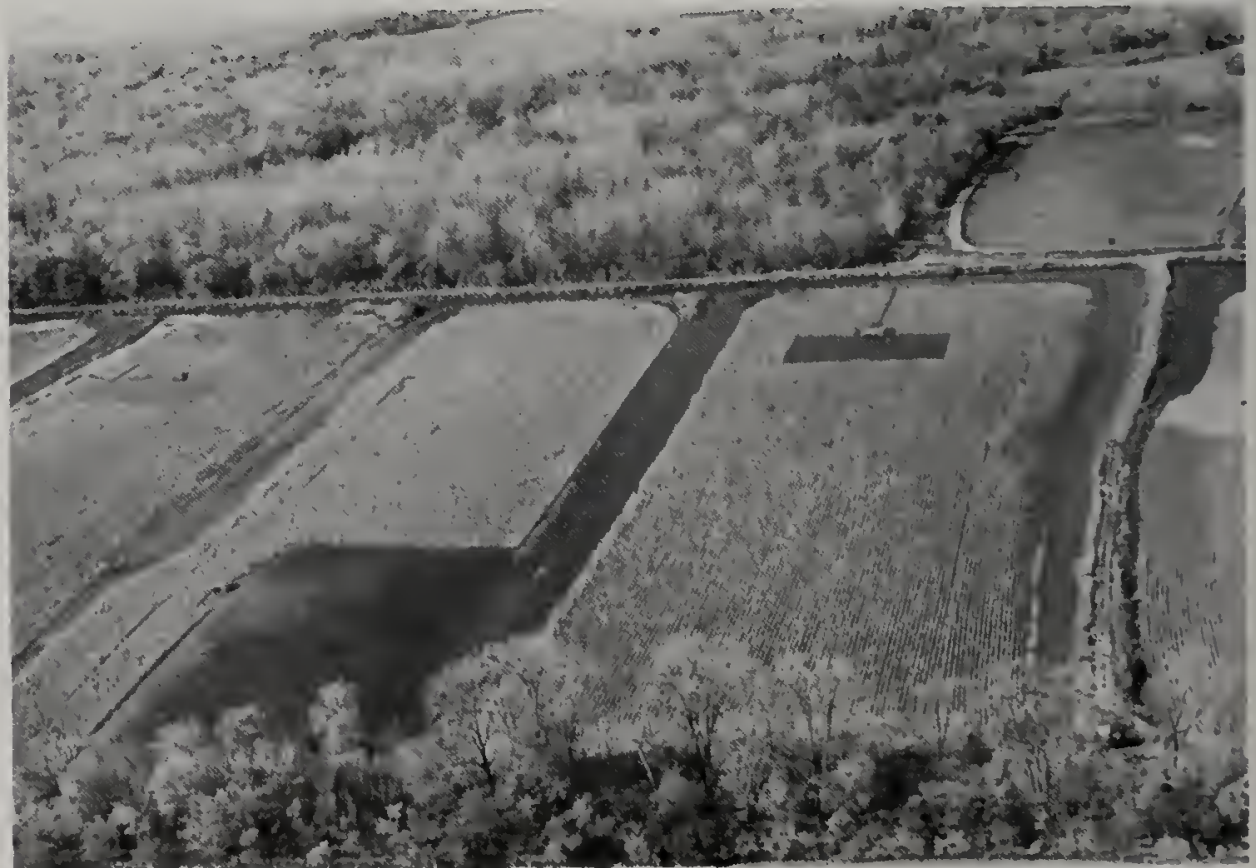

Fig. 24.-A harvested corn field, with cleared areas in front of duck blinds for decoys. flooded to attract mallards during the hunting season. Note the small levees used to impound water pumped from adjacent wells. 
kill by private clubs in the Illinois River valley (Bellrose 1944). It became necessary for duck clubs to develop alternative sources of duck food if they were to continue to enjoy a semblance of quality hunting. Although waste corn left after harvest by mechanical pickers temporarily filled the food requirements of mallards, their field feeding was not necessarily conducive to good hunting in bottomland lake habitats.

Consequently, in the late 1930's the more alert and affluent duck clubs began constructing levees to provide adequate water control, the key to in- creasing the growth of waterfowl food plants. World War II interrupted this levelopment, but in subsequent years more and more tracts of bottomland have been brought under some degree ol low-water control.

A questionnaire sent in September 1978 to 219 duck clubs in the Illinois Valley [those of the 252 clubs owning more than 16 ha (40 acres)] elicited information on impounded areas. About one-third of the lands controlled by private clubs have levees or other structures that permit a degree of water control (Table 17). The heights of the levees, as reported in the question-

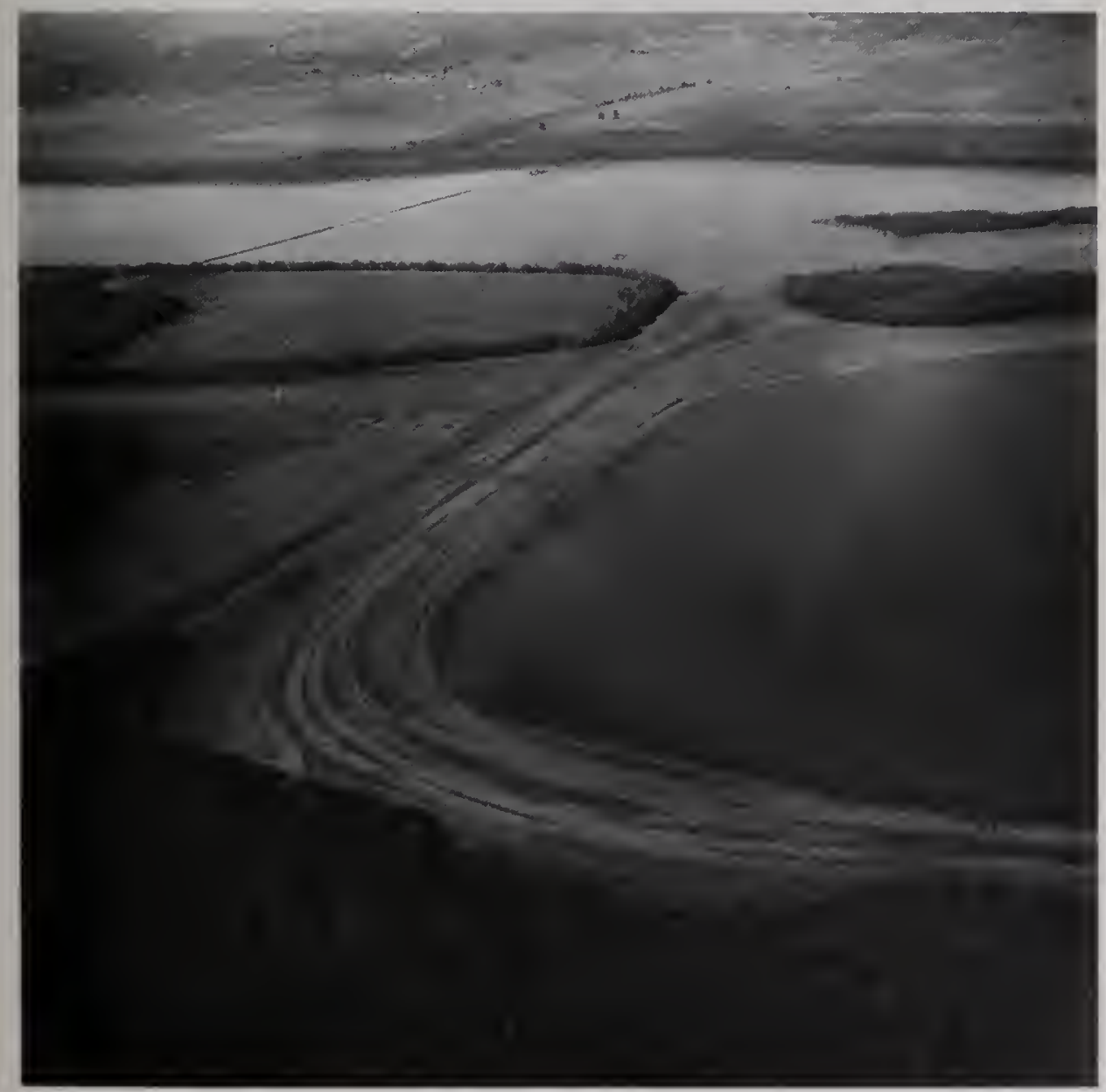

Fig. 25. - Beds of Japanese millet sown from a light aircraft on mud flats by a duck club to attract waterfowl. To make seeds available for dabbling ducks, millet beds are flooded during the fall. 
naire, varied from 0.9 to $1.8 \mathrm{~m}(3-6$ $\mathrm{ft})$. Although not high enough to keep out most spring floods, these structures are adequate to prevent flooding by many (but not all) rises during the summer.

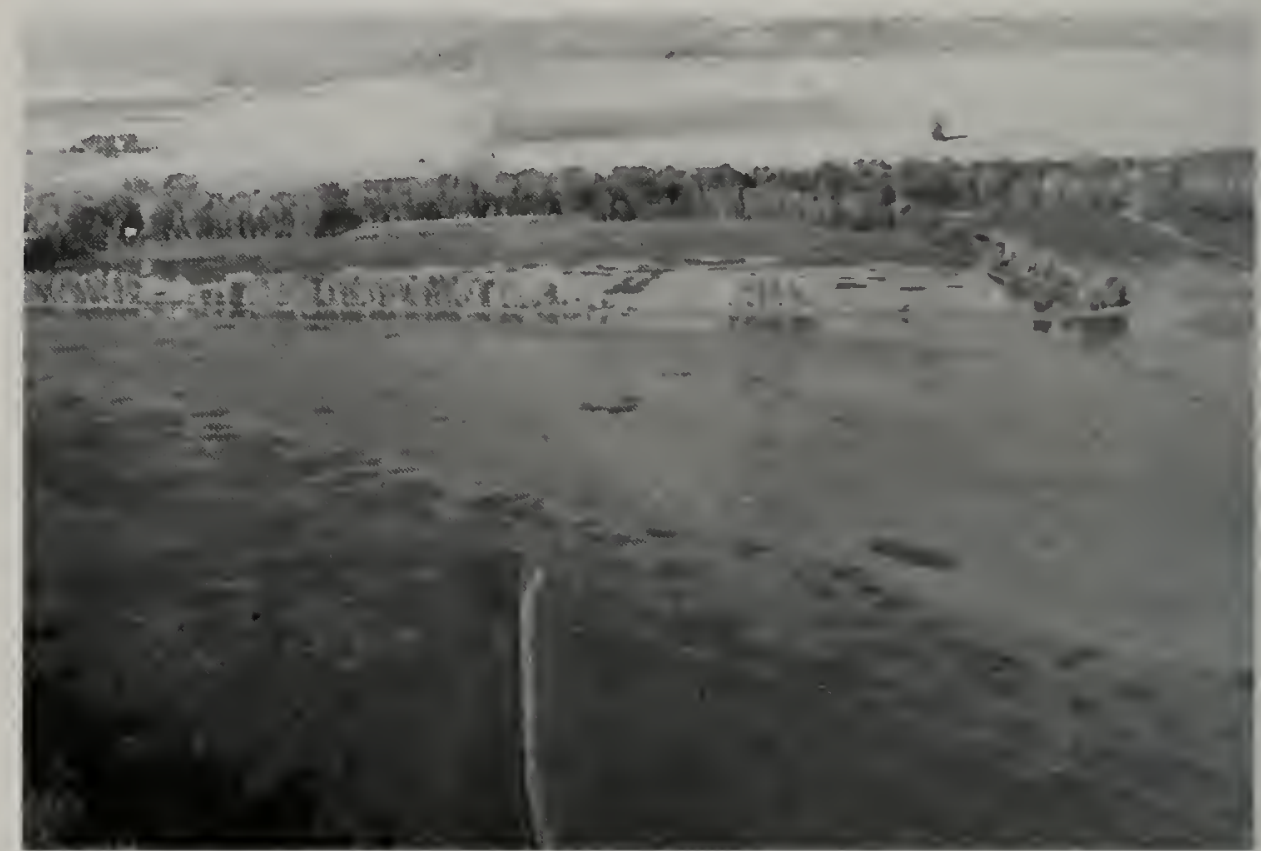

Fig. 26.-Duck club impoundment on Goose Lake, north of Havana, where moist-soil duck food plants volunteered following dewatering.

Table 18.-Waterfowl lands under state and federal ownership in the Illinois River valley, with the area of impoundments subject to or available for dewatering. Area figures are in hectares $(2.471$ acres/hectare).

\begin{tabular}{|c|c|c|c|c|c|}
\hline Location & $\begin{array}{c}\text { State or } \\
\text { Federal } \\
\text { Ownership }\end{array}$ & $\begin{array}{l}\text { Total } \\
\text { Area }\end{array}$ & $\begin{array}{c}\text { Water } \\
\text { Arca }\end{array}$ & $\begin{array}{c}\text { Area Subject } \\
\text { to Water } \\
\text { Level Control }\end{array}$ & $\begin{array}{l}\text { Percent } \\
\text { of Water } \\
\text { Area with } \\
\text { Water Levc] } \\
\text { Concrol }\end{array}$ \\
\hline Lake Depue & $\mathbf{S}$ & 826.0 & 212.1 & 10.1 & 4.8 \\
\hline Cameron Unit & $\mathbf{F}$ & 257.6 & 157.0 & 0.0 & 0.0 \\
\hline \multicolumn{6}{|c|}{ Sparland, Marshall County, } \\
\hline \& Spring Branch & $\mathbf{S}$ & $2,241.3$ & $1,621.6$ & 0.0 & 0.0 \\
\hline Woodford County & $\mathbf{S}$ & $1,173.9$ & 996.5 & 0.0 & 0.0 \\
\hline Pekin Lake & $\mathbf{S}$ & 602.2 & 221.8 & 0.0 & 0.0 \\
\hline Spring Lake & $S$ & 801.6 & 520.0 & 300.0 & 57.7 \\
\hline Rice Lake & $\mathrm{S}$ & $1,068.3$ & 559.8 & 306.4 & 54.7 \\
\hline Lake Chautauqua & $\mathbf{F}$ & $1,804.5$ & $1,378.0$ & 413.4 & 30.0 \\
\hline Anderson Lake & $S$ & 863.0 & 551.8 & 2.0 & trace \\
\hline Sanganois & $\mathrm{S}$ & $3,487.5$ & 689.3 & $1,099.6^{\circ}$ & 100.0 \\
\hline Meredosia Lake & $\mathbf{F}$ & 748.7 & 63.1 & 30.6 & 48.5 \\
\hline \multicolumn{6}{|l|}{ Calloun County \& } \\
\hline adjacent areas & $S$ & $4,509.9$ & $1,375.9$ & 752.7 & 62.3 \\
\hline Calhoun unit & $\mathbf{F}$ & $2,043.7$ & $1,094.6$ & 74.9 & 6.8 \\
\hline Total & & $20,428.2$ & $9,471.5$ & $2,9 \mathcal{S 9 . 7}$ & 31.7 \\
\hline
\end{tabular}

The larger area under water level control results from the potential inundation of bottomland timber within the impoundment. 
The duck clubs use some of the impoundments to grow corn that matures iI 90 days, sorghum, buckwheat, or a combination (Fig. 24). However, most impoundments are used to develop moist-soil vegetation; either Japanese millet seed is broadcast on mud flats, or native plants are permitted to volunteer and grow naturally (Fig. 25). An increasing number of clubs are relying at least to some degree on nature to provide food from volunteer native species (Fig. 26).

State and federal waterfowl areas i.1 the Illinois Valley have also been dereloped to provide control of water levels in the summer and fall. Data in Table 18 show the areas of impoundments on state and federal public shooting grounds and refuges. Nearly 20 percent of the government areas liave water management, a lower proportion than the 33.8 percent of private duck clubs.
The degree to which these low levees permit dewatering in summer and flooding in the fall clepends upon their height. The percentages of the years 1938-1976 in which water would have overtopped a particular elevation on the Henry gauge, Peoria Pool, between 15 July and 15 October were calculated from average gauge readings and are shown in Fig. 27. Similar data are shown for the Havana gauge, La Grange Pool (Fig. 28). To correct for locations upstream from the respective gauges, add $1.3 \mathrm{~cm} / \mathrm{km}(0.8 \mathrm{incl} / \mathrm{mile})$; downstream, subtract $1.3 \mathrm{~cm} / \mathrm{km}$.

At Henry any levee elevation up to $134.7 \mathrm{~m}$ (442 ft) msl would be overtopped about 1 year in every 3 , and at $135.3 \mathrm{~m}(444 \mathrm{ft}) \mathrm{msl}$, 1 year in every 5. Overtopping $132.1 \mathrm{~m}(433.3 \mathrm{ft}$ ) $\mathrm{msl}$ levees on the Havana gauge has occurred about every other year, and 133.3-m (437.3-ft) msl levees were overtopped 1 year in every 5 . The La
Fig. 27. The percentage of years, 1938-1976, that water levels would have overtopped a levee of given elevation on the Henry gauge in the Peoria Pool from 15 July to 15 October.

Fig. 28.-The percentage of years, 1938-1976, that water levels would have overtopped a levee of given elevation on the Havana gauge in the La Grange Pool from 15 July to 15 October.

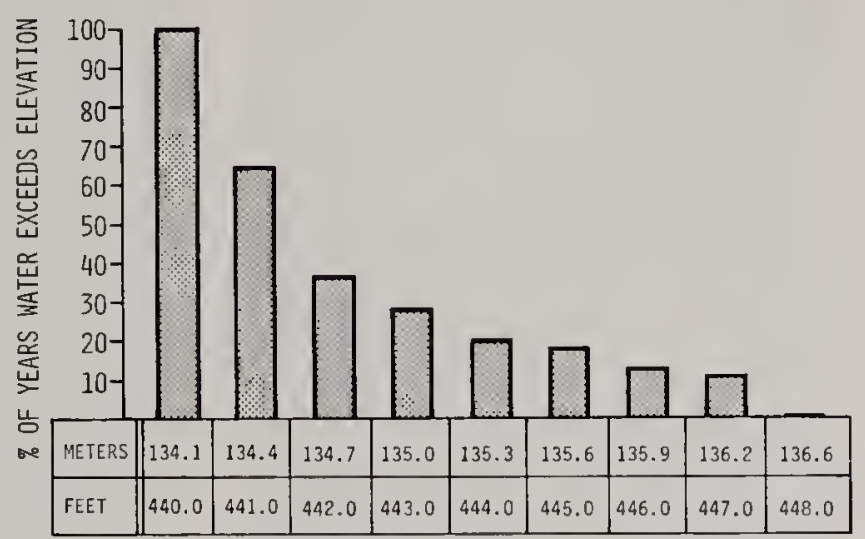

MSL ELEVATION, HENRY GAUGE, ILLINOIS RIVER

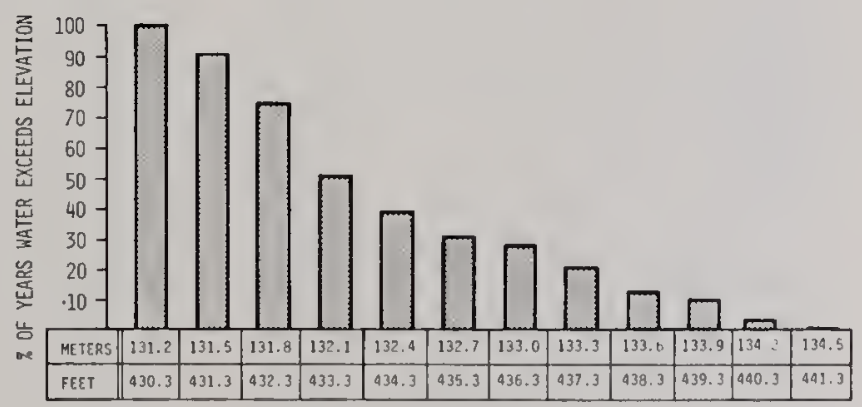

MSL ELEVATION, HAVANA GAUGE, ILLINOIS RIVER 
Grange Pool is subject to more frequent flooding than the Peoria Pool because of the entrance of the Mackinaw and Spoon rivers below Peoria.

The lower the levee, the lower its initial cost and subsequent maintenance costs. Shallow waters limit the size of waves; as waters cleepen, waves grow, as do their erosive effects on levees. Once flood waters overtop levces, their erosive force is diminished. Consequently, in determining the height of a levee, two opposing factors must be considered: The higher a levee, the more it will cost to build and maintain, but the more summer floods (15 July-15 October) it will exclude. To attempt to exclude summer floods in all years would be unrealistic.

\section{DISCUSSION}

The degradation of bottomland lakes in the Illinois Valley by sedimentation lias adversely affected waterfowl. Aquatic and marsh vegetation declined almost to the point of extinction during the middle years of the study period (1938-1976). In the last decade, only remnant beds of the most tolerant plants-American lotus, river bulrush, and marsh smartweed-have persisted. Of all aquatic and marsh plants in the Midwest, these species are the best adapted to fluctuating water levels and turbiclity. Unfortunately, they are poor duck foods. American lotus seeds are too hard to be palatable to most clucks (Bellrose \& Anclerson 1943). River bulrush and marsh smartweed produce little seed under the existing harsh conditions-even less than the yield reported earlier by Low \& Bellrose (1944).

Aquatic and marsh plants used as food by waterfowl disappeared from the bottomland lakes of the Illinois Valley either because of altered water levels or because of increased turbidity. Altered water levels were of local im- portance, but turbidity increases were widespread and far more significant.

Turbiclity increased because of increased sedimentation. According to a study by Jackson \& Starrett (1959:166), waves produced by winds and movements of rough fish resuspended the fine bottom sediments. They concluded, "The resuspension of sediment particles, which were originally carried and deposited in the lake by flood waters of the lllinois River, caused the high turbiclities at Lake Chautauqua." Stall \& Melsted (1951) reported that although the largest sediment particles at Lake Chautauqua began to settla soon after disturbance ceased, much of the sediment took from 7 to 12 davs to scttle to the bottom.

Studies of sedimentation in bottomland lakes by Stall \& Melsted (1951), Lee et al. (1976 umpublished), Lee \& Stall (1976 unpublished), and by us demonstrate that these lakes are filling with secliment at an alarming rate. On three lakes-Upper Peoria, Chautauqua, and Meredosia-analyses of two different time periods show that the annual rate of seclimentation at a given water depth has increased. Because in two of the three lakes the earlier period (which showed a lower sedimentation rate) included more years, the sediments deposited in this period have been buried more deeply than more recently deposited sediments and thus maty have been subjected to a greater degree of compaction (David L. Gross, Illinois State Ceological Survey, personal communication). However, compaction alone cannot explain the great differences between the two periods' sedimentation rates. Hence, we conclude that strcams tributary to the Illinois River are now transporting more secliment into the main channel than they previously clirl.

Sediment tends to make lake bottoms more uniform because more material is deposited on deep than on shallow bottoms. Whereas at the turn of the century bottomland lake becls had di- 
versified clepths, they now invariably slope almost imperceptibly from shore to center. At normal water level, average clepths at the centers of 11 bottomland lakes now vary from 10.2 to $109.2 \mathrm{~cm}$ (4-43 inches) with a mean of $47.2 \mathrm{~cm}$ (18.6 inches). When water levels are at the margins of the wooded shorelines, it takes little additional reduction in water levels to expose large sections of the lake basins as mud flats. When water level reductions occur in early summer (up to 15 July), black willows, cottonwoods, and soft maples volunteer and grow rapidly on the newly exposed mud flats. In an amazingly short span of years, what had once been part of the lake basin accrues to the bottomland forest and is lost as potential mud flats for the development of moist-soil waterfowl food plants.

During the period 1933-1976, over 1,376 ha $(3,400$ acres $)$ of water surface (4.2 percent of the total lake acreage) in the bottomland lakes below Spring Valley were lost to sedimentation. The bottomland forest invadect as the water surface shrank (Bellrose et al. 1977); this process is continuing at an accelerating rate. Lee \& Stall (1976 unpublished) predicted that in 33 years sedimentation will entirely fill the basin of Lake Depue.

Lee (1976 unpublished) studied the filling of Lake Chautauqua by secliment and concluded that its life expectancy was 92 years. At Meredosia Bay, I.ce et al. (1976 unpublished) reported that sediment will fill the lake in 90 years. Because Peoria Lake is quite deep and the Illinois River flows through it, Peoria Lake will be the last lake in the valley to become extinct from sedimentation.

The loss of aquatic and marsh duck food plants combined with the evershallower bodies of water have caused private duck clubs, the Illinois Department of Conservation, and the U.S. Fisl and Wildlife Service to turn increasingly to dewatering as a method of producing moist-soil vegetation for duck food.

The dewatering technique requires that mud flats be exposed for 70-90 days between $15 \mathrm{July}$ and 15 October. Dewatering can be accomplished either by below-normal river levels during this time span or by managers' pumping out excess water. Small levees must isolate the managed unit from the river to minimize minor river fluctuations and to impound waters for inundating moist-soil plant beds after 1 October. Our studies show that the more comp'ete the separation of backwater areas from the river, the better the development of waterfowl food plants.

Under the most favorable summer water levels, a maximum of 44 percent of the 28,329 ha $(70,000$ acres) in lake basins of the Illinois Valley would be available for moist-soil plant development. Because small summer water rises frequently reflood mud flats, moist-soil plant development is usually limited to between 3 and 20 percent of the basin area in the valley. However, each year additional acreage is being brought under some degree of water level control by private duck clubs and the Illinois Department of Conservation, thereby increasing the potential area available for moist-soil plant development.

Although a number of marsh managers in the Illinois Valley sow agricultural crops on the drier sites and Japanese millet on the wetter sites, it is doubtful whether this practice is justified. Most volunteer moist-soil plants are used intensively by waterfowl, which find them highly palatable (Bellrose \& Anderson 1943). Cocklebur is the most important exception. but this "weed" species can be controlled by a brief reflooding.

Other species of moist-soil plants of value as duck food are more tolerant of temporary flooding than is cocklebur. All moist-soil plant species considered in this studly perish when com- 
pletely inundated. However, after germination and early growth on mud flats, some species continue to grow with the basal part of their stems in water. Rice cutgrass and Walter's millet are species most tolerant of prolonged basal inundation.

It is imperative that the moist-soil waterfowl food resources of the valley be enhanced. This enlancement can only be accomplished through more extensive construction of low levees, which, in conjunction with the use of pumps, will enable lakes or parts of lakes to be dewatered during the summer and flooded cluring the fall.

Over the past four decades, mallards have been able to obtain a large proportion of their food from waste corn in harvested fields (Anderson 1959). However, fall plowing and reduced waste grain, stemming from more efficient combines and new plant varieties, have reduced the availability of corn to mallards. No doubt improvements in harvest equipment and plant varieties will continue to decrease the availability of waste grain. Therefore, if mallard populations are to be maintained at current levels, the native food resources will have to be enhanced. Because water turbidity suppresses the growth of aquatic duck food plants in the Illinois Valley, the development of moist-soil plant resources provides the only feasible means of accomplishing this objective.

Under present cultural practices, farmlands of the Illinois River basin will continue to be subject to severe sheet erosion, tributaries will continue to transport soil particles into the Illinois River, and turbidity and sedimentation will continue to degrade and fill the shallow bottomland lakes.

If the degradation of wildlife values of the Illinois Valley is to be minimized, present levels of soil erosion must be reduced. The single most effective means of accomplishing this goal would be the adoption of min- inum tillage practices on slopes devoted to open row crops. Slopes that erode severely should be restricted to small grain, hay crops, or permanent pastures.

Stream bank erosion also merits attention. In the last decade, the removal of trees and other woody regetation from hundreds of miles of stream banks has greatly accelerated soil loss. A protective "green belt" is needed along tributary stream banks if this source of sediment is to be reduced.

Unless stern measures are taken in the near future, the lateral bottomland lakes of the Illinois River are loomed to early extinction.

\section{SUMMARY}

1.-The bottomland (backwater) lakes of the Illinois River valley embrace about 28,500 ha $(70,000$ acres $)$ and attract hundreds of thousands of waterfowl during their fall and spring migrations. All of these backwater lakes except Peoria Lake are lateral to the river channel.

2.- The Illinois River occupies a valley much olcler than the river itself as a result of a series of unique geological events. This valley in essence was the Mississippi River valley before the Wisconsinan glaciation. Its bottomland lakes developed because the river's remarkably low rate of fall resulted in its aggrading rather than degrading.

3.-Unfortunately, the very principles of sedimentation that created the lakes also set the stage for their extinction. Under pristine conditions this extinction would have taken hundreds, perhaps thousands, of years, but man. through intensive use of the land, has greatly accelerated the process.

4.-Aquatic and terrestrial habitats of the Illinois Valley have suffered a series of cataclysmic events since 1900: first, a permanent rise in water level from water diverted from Lake Michigan; second, the draining of more 
than half of the 161,878 -ha $(400,000$ acre) floodplain through the construction of levees and pumping stations; third, an upsurge in untreated urban and inclustrial pollution during the 1920 's; fourth, the creation of a $2.7-\mathrm{m}$ (9-ft) channel and its attendant navigation dams in the 1930's; and fifth, an acceleration in sedimentation rates following World War II, apparently resulting from an increase in the amount of open row crops grown within the basin.

5.-Waterfowl food plant resources have been dramatically altered by the many changes wrought by man. Factors that have directly affected the species composition and abundance of the wetland plants are (1) fluctuating water levels, (2) water turbidity, (3) water depth, and (4) competition between plant species.

6.-Fluctuating river levels adversely affect the development of aquatic and marsh vegetation on those bottomland lakes connected with the river at all stages. In the early years of the study, the more the lakes were separated from the river, the more extensive were their aquatic and marsh plant beds.

7.-During the carlier years of the study, aquatic and marsh plants disappeared from those lakes connected with the river at all water stages (and thus subject to water-level fluctuations). During the later years of the study, aquatic plants disappeared and the area of marsh plants greatly declined in all lakes, even in those enjoying a degree of scparation from the river and minimal water-level fluctuations. Increases in water turbiclity and bottom softness, stemming from sedimentation, appear to be responsible.

8.-However, low levees and pumps have increasingly been used to dewater all or part of the lake basins. This procedure controls small summer fluctuations and cxposes mud flats for the development of moist-soil plants be(ween 15 July and 15 October. Moist- soil plants-millets, smartweeds, nutgrasses, rice cutgrass, water hemp, and teal grass-produce an abundance of seed palatable to many species of ducks. Low summer water levels permit or expedite dewatering. Summer rises that overtop low levees usually destroy moist-soil plant beds.

9.-Sedimentation is rapidly filling in the bottomland lakes of the Illinois Valley, reducing their size, degrading water quality, and minimizing the diversity of bottom deptlss. The fine silts and clays deposited on the bottoms when river waters invade bottomland lakes are readily resuspended by wave action and the activity of rough fish. The consequent turbidity reduces the euphotic zone to such a shallow depth that acpuatic plants can no longer survive. Marsh plants have difficulty maintaining footings as bottom soils become softer.

10.-Seclimentation occurs at a higher rate in deep water than in sluallow water. Thus, most lakes now possess a uniform bottom instead of the turn-of-thecentury variation in bottom depths. (Peoria Lake, through which the river channel passes, is an exception.) Lake basins are now platter shaped. Estimited life expectancies are 33 years for Lake Depuc, 92 years for Lake Chantauqua, and 90 years for Meredosia Bay.

11.-The abundance of certain species of waterfowl in the Illinois Valley is related to the abundance of native food resources. Among the dabbling ducks, the size of fall populations of the pintail, green-winged teal, and wigeon correlated with the abundance of wetland plants. Mallards feed extensively on waste grain in harvested fields, but even so, when annual variations in the continental mallard population were taken into account, moistsoil plant abundance influenced the abundance of mallards. Diving duck populations were unrelated to wetland plant abundance. However, when a 
catastrophic loss of fingernail clams occurred, diving duck numbers crashed. Neither this food resource nor the population of diving ducks has recovered in the ensuing two decades.

12.-Fall river levels determine the depths in bottomland lakes and thus the availability of moist-soil plant foods. If the river is low and mud flats are exposed, moist-soil plant seeds will be unavailable to waterfowl. If, on the other hand, the river is high and mud flats are too deeply submerged, the result is the same. The higher the fall rise in water, the greater the reduction in numbers of green-winged teal, with the same influence to a lesser degree on pintails, wigeons, and mallards.

13.-As a result of the disappearance of aquatic plants and the prohibition of baiting, private duck clubs, the Illinois Department of Conservation, and the U.S. Fish and Wildlife Service have placed increasing empliasis on controlled dewatering of wetland habitats. Private duck clubs control 23,198 ha $(57,320$ acres $)$ of land and water in the Illinois Valley and have 6,723 ha (16,612 acres) under varying degrees of low water level control. State and federal agencies control 15,644 ha $(38,656$ acres) and have 4,688 ha (1 1,585 acres) under similar water-level management. 


\section{LITERATURE CITED}

ANDERSON, H. G. 1959. Food habits of migratory ducks in Illinois. Illinois Natural His. tory Survey Bulletin 27(4):289-344.

Barrows, H. H. 19]0. Geography of the middle Illinois V'alley. Illinois State Geological Survey Bulletin 15. 128 p.

Bellrose, F. C., JR. 1941. Duck food plants of the lllinois River valley. Illinois Natural History Survey Bulletin 2](8):237-280.

1944. Duck populations and kill: an evaluation of some watesfowl regulations in Illinois. Illinois Natural History Survey BuIletin 23(2):327-372.

-, and H. G. Anderson. 1943. Preferential rating of duck food plants. Illinois Nat. ural History Survey Bulletin 22(5):417-433. and R. 1). Crompton. 1970. Migrational behavior of mallards and black clucks as detcumincel from banding. Illinois NaturaI History Survey Bulletin 30(3): 167-234. R. E. Siarks, F. L. Paveglio, JR., D. W. StefFeck, R. C. Thomas, R. A. Weaver, and D. MoLL. 1977. Fish and wildlife habitat changes resulting from the construction of a nine-foot navigation channel in the Illinois Waterway from La Grange Lock and Dam upstream to Lockport Lock and Dam. U.S. Army Corps of Engineers District, Cliicago. 120 p.

Evans, R. L., and D. H. SChnepper. 1977. Sources of suspended sediment: Spoon River, Illinois. North-Central Section, Geological Society of Amcrica meeting. Carbondale, Illinois. $9 \mathrm{p}$.

Forbes, S. A., and R. E. Richardson. 1919. Some recent changes in Illinois River biology. Illinois State Natural History Survey Bulletin 13(6):139-156.

- 1920. The fishes of 11linois. 2nd ed. Illinois Natural History Survey. cxxxvi + 357 p.

lelinols Cooperative Crop Reporting Service. 1968. Illinois agricultural statistics, field crops by counties, twenty-one years, 19451965. Bulletin 68-4. Springfield. $155 \mathrm{p}$.

1977. Illinois agricultural statistics annual summary 1977. Bulletin 77-1. Springfield. $106 \mathrm{p}$.

JACksoN, H. O., and WV. C. Starrett, 1959. I urbidity and sedimentation at Lake Cliantauqua, Illinois. Journal of Wildlife Management 23(2):157-168.

KofoId, C. A. 1903. Plankton studics. IV. The plankton of the Illinois River, 18941899, with introductory notes upon hydrography of the Illinois River and its basin. Part I. Quantitative investigations and gen- cral results. Illinois State Laboratory of Natural History Bulletin 6(2):95-629.

Low, J. B., and F. C. Bellrose, JR. 1944. The secel and regetative yeld of waterfowl food plints in the lllinois River valley. Journal of Wilclife Management 8(1):7-22.

NH.LS, H. B., W. C. Starrett, and F. C. BELLRosE. 1966. Man's effect on the fish and willlife of the lllinois River. Illinois Natural History Survey Biological Notes 57 . $24 \mathrm{p}$.

Mutritil, W. F., and L. D. Cornısh. 1929. Flood control rcport: an engineering study of the Ilood situation in the statc of Illinois. Jlinois Division of Waterways. $402 \mathrm{p}$.

National. Oceanic and Atmospheric AdminisTRATION ENIIRONMENTAL DATA AND INFORMation Service (U.S. Weather Bureau). 1939-1976. Daily River Stages Vol. 37-Vol. 72.

PURDY, W. C. 1930. A study of pollution and natural purification of the Illinois River. II. The plankton and related organisms. U.S. Public Ilealth Service Bulletin 198. 212 p.

Richardson, R. E. 1921. The small bottom and shore fauna of the middle and lower llinois River and its connecting lakes, Chillicothe to Grafton: its valuations; its sources of food supply; and its relation to the fishery. Illinois State Natural History Survey Bulletin 13(15):363-522.

Stali, J. B., and S. W. MElsted. 1951. The silting of Lake Chautauqua, Havana, Illinois. Illinois State Watcr Survey, in cooperation with Illinois Agricultural Expericent Station, Report of Investigation 8. $15 \mathrm{p}$.

StarretT, W. C. 1971. A survey of the mussels (Unionacea) of the Illinois River: a polluted stream. Illinois Natural History Survey Bulletin 30(5):267-403.

U.S. ARMY CORPS OF ENGINEERS, U.S. ENGINEERS Office, Chicago, Illinors. 1933. Illinois and Des Plaines Rivers from mouth of the Illinois River to Lockport, Illinois.

WILl.MAN, H. B. 1973. Gcology along the Illinois Waterway-a basis for environmental plaming. Illinois State Geological Survey Circular $478.48 \mathrm{p}$.

__, and J. C. Frye. 1970. Pleistocene stratigraplyy of Illinois. Illinois Statc Geolog. ical Survey Bulletin 94. 204 p.

WoermanN, J. W. 1902-1904. Map of the sccondary triangulation system of the Illinois and Des Plaines Rivers from Chicago, Illinois to the Illinois River. Corps of Engineers, Chicago Office, U.S. Army. 


\section{LIST OF COMMON AND SCIENTIFIC NAMES}

With few exceptions the classification of the plants follows Gray's New Manual of Botany, seventh edition. The waterfowl classification follows Bellrose's Ducks, Geese and Swans of North America, second edition.

\section{PLANTS}

Algae

Cattail

Giant bur-reed

Pondweeds

Longleaf pondweed

Leafy pondweed

Sago pondweed

Southern naiad (also called bushy pondweed)

Arrowleaf (also called arrowhead)

Duck potato

Waterwced (also called elodea)

Wild celery

Teal grass (also called love grass)

Rice cutgrass

Wild rice

Wild millet (also called duck millet, bamyard grass)

Japanese millet

Walter's millet

Sorghum

Corn

Soybeans

Nutgrasses

American bulrush

Softstem bulrush (also called roundstem bulrush)

Hardstem bulrush

River bulrush

Spike rush

Duckweeds

Pickerel weed

Water stargrass (also called mud plantain)

Black willow

Cottonwood

Pin oak

Pecan

Buckwheat

\author{
Chlorophyceae \\ Typha latifolia, $T$. \\ angustifolia \\ Sparganium \\ eurycarpum \\ Potamogeton spp. \\ Potamogeton nodosus \\ Potamogeton foliosus \\ Potamogeton \\ pectinatus \\ Najas guadalupensis
}

Sagittaria calycina (formerly Lophotocarpus calycinus)

Sagittaria latifolia

Anacharis canadensis

Vallisneria americana

Eragrost is hypnoides

Leersia oryzoides

Zizania aquatica

Echinochloa crusgalli

Echinochloa

frumentacea

Echinochloa walteri

Sorghum bicolor

Zea mays

Glycine max

Cyperus spp.

Scirpus americanus

Scirpus validus

Scirpus acutus

Scirpus fuviatilis

Eleocharis palustris

Spirodela polyrhiza,

Lernna spp.

Pontederia cordata

Heteranthera dubia

Salix nigra

Populus delloides

Quercus palustris

Carya illinoensis

Fagopyrum

esculentum
Nodding sma rtweed

Marsh smartweed

Largeseed smartweed

Swamp smartweed

Water hemp (also called pigweed, hog. weed)

Coontail

Yellow pond lily

White water lily

American lotus

Soft maple (also called silver maple)

Marsh mallow

Cocklebur

Spanish needles

\section{ANIMALS}

\section{Mollusca}

Fingernail clams

\section{Fish}

Carp

\section{Birds}

Wood duck

American wigeon

American green-

winged teal

Mallard

Pintail

Blue-winged teal

Canvasback

Ring-necked duck

Lesser scaup

Ruddy duck

Coot
Polygonum lapathifolium

Polygonum coccineum (formerly muhlen. bergii)

Polygonum pennsylvanicum

Polygonum hydropiperoides

Amaranthus tuber. culatus (formerly Acnida tuberculata)

Ceralophyllum dernersum

Nuphar luteum (formerly Nymphaea advene)

Nymphaea tuberosa (formerly Castalia tuberosa)

Nelumbolutea

Acer saccharinum

Hibiscus militaris

Xanthium spp.

Bidens spp.
Sphaeriidae

Cyprinus arpio

Aix sponse

Anas americana

Anas crecca carolinensis

Anas platyrhynchos platyrhynchos

A nas acute acuta

Anas discors

Aythya valisineria

Aythya collaris

A thya affinis

Oxyura jamaicensis rubida

Fulica americana 


\section{INDEX}

\section{Algae, 4, 41}

A

Aquatic plants, $3,6,8,9,12,14,18,20,21$, $22,23,27,28,36,37,46,47,48$

American lotus, 14, 18, 20, 21, 22, 23, 27, 28, 46

coontail, 3, 4, 18, 21, 22, 23, 27, 28, 36

longleaf pondweed, $20,22,23$

pondweeds, 4, 18, 22, 27

sago pondweed, $20,21,22,23,28,36$

southern naiad, 18, 22, 23, 36

waterweed, 18

white water lily, 22, 23, 27

wild celery, 4

\section{B}

Banks (natural levees), 1, 2, 10, 18, 31

Big Bend, 1

Bottomland forest, 3

black willow, 27, 28, 47

cottonwood, 47

pccan, 4

pin oak, 4

soft maple, 47

Bottomland lakes, evaluation of, 1, 2

classes, 9, 14, 18

class $1,9,14,18,20$

class $11,9,14,18,20$

class $111,9,14,18$

class IIIA, 9, 18, 20, 21, 22

class $111 \mathrm{~B}, 9,18,20$

class IV, 9

\section{C}

Chautauqua National Wildlife Refuge (see also Lake Chautauqua), 21

Chicago (Mctropolitan) Sanitary District, 3, 4 Chicago Sanitary and Ship Canal, 3, 4

Coot, 36, 37

Corn (waste), 34, 35, 38, 41, 43, 45, 48

\section{D}

Des Plaincs River, ]

Dewatering, $9,10,12,18,41,43,44,45,47,48$ Diversion (water from Lake Michigan), 3, 4, 12

Duck clubs, 9, 43, 45, 47

Duck-day use, $8,9,38,40,41$

Ducks, dabbling, 20, 35, 37, 39, 41

bluc-winged teal, 37,39

grecn-winged teal, 36, 37, 39, 40, 41

mallard, $4,35,37,38,39,40,41,43,48$

pintail, $35,37,39,40,41$

wigcon, $36,37,39,40,41$

wood duck, 4

Ducks, diving, $35,39,41$

canvasback, $39,40,41$

lesser scaup, 35, 39, 40, 41

ring.nccked duck, 39,40

ruddy duck, 39

Duration of Stay Index, 40, 41
Fall plowing, 48

l'ingernail clams, 41

Floods, cffect of, 22, 23, 46

G

Glaciation, Wisconsinan, I

Green-beIt, 48

Growth-pcriod index, 8

H

History

geological, ]

human, 2, 3

\section{I}

1llinois Department of Conservation, 9, 47

K

Kankakee River, 1

Lake

Anderson, 6, 23, 27, 30, 31

Babbs (Slough), 6, 32

Billsbach, 6, 32

Chautauqua, 6, 21, 22, 28, 29, 30, 31, 34, 16 47

Cuba Island, 22

Depue, 34, 47

Douglas, 23

Flat, 22, 23

Gilbert, 22, 36

Mercdosia (Bay), 6, 30, 31, 34, 46, 47

Peoria (Upper), 6, 8, 24, 29, 30, 31, 32, 46, 47

Rice, $6,22,23,30,31,32$

Sawmill, 6, 32

Senachwine, 6

Sparland, 6, 32

Spring, 9, 23, 27

Swan (Flat), 8, 22, 23, 36

Thompson, 3

Wightman, 6, 32

Lake-bottom profile(s), 3]

Lakc Michigan, 3, 4, I2

Levec and drainage districts, 4

Levec clevations, 9, 45, 46, 47, 48

\section{M}

Mackinaw River, 29, 46

Mark Twain National Wildlife Refuge, 8, 22

Marsh plants, $3,6,8,9,12,21,23,35,36,46$, 47

duck potato, 14, 18, 20,21, 23

marsh smariwced, 14, 18, 20, 22, 23, 27, 28, 46

pickerel weed, 18,27

river bulrush, 14, 18, 20, 21, 22, 23, 27, 46

wild rice, 18, 27

Memphis Datum, 6

Minimum tillage, 48 
Mississippi River, 1, 12, 22

Moist-soil plants, $5,6,8,9,12,14,18,20,21$, $23,35,37,39,41,45,47,48$

arrowleaf, 18, 20

cocklcbur, 18, 47, 48

Japanese millet, 18, 20, 45, 47

largeseed smartweed, 18

nodding smartweed, 18

nutgrasses, 18,20

rice cutgrass, $18,20,22,48$

Spanish needles, 18

teal grass, 18, 20

WaIter's millet, 18, 20, 48

water hemp, 18,20

wild millet, 18,20

Moist-Soil Water-Level Index, 8, 9, 20, 21, 37, $38,39,41$

Mud flat(s), 8, 12, 18, 20, 21, 39, 41, 45, 47, 48

\section{N}

Navigation dams, $1,3,4,12,13$

Alton, 4, 12, 22

Brandon Road, 12

Copperas Creek, 3

Dresden Island, 12

Henry, 3

La Grange, 3, 4, 12, 13, 45

Lockport, 12

Marseilles, 12

Peoria, 3, 4, 12, 13, 20, 23, 45, 46

Starved Rock, 4, 12

Plankton, 3, 27

Plant competition, 9, 18, 22, 23, 35

Pollution

domestic, 27

urban, 4

$\mathbf{R}$

River gauges

Havana, $8,12,45$

Henry, 8, 12, 45

S

Sedimentation (rates), 1, 4, 6, 9, 23, 28, 29, 30, $31,32,34,46,47,48$
Seeds

availability, 39,48

maturity, 12,18

preference, 36,46

production, 20,41, 48

yield, 35

Soil crosion, $29,34,48$

bank, 31,48

Spoon River, 2, 29, 46

Surface area

bottomland lakes, 4,48

row crops, $34,45,48$

soybeans, 34

$\mathbf{T}$

Turbidity (see water transparency)

$\mathbf{U}$

U. S. Fish and Wildlife Service, 9, 47

V

Vegetation maps, 8

\section{W}

Water depth(s), 6, 9, 20, 23, 24, 27, 28, 47

Waterfowl areas

federal, 45

state, 45

Waterfowl censuses, 8

Water-level index, 8

Water levels, 12, 13

fall, $39,40,41,48$

fiuctuation, $9,12,20,23,28,46$

stability, 14, 27

summer, 39, 40, 41, 47

Water-Stability Index, 9, 21, 22

Water transparency, 3

fish activity (effect of), 28, 46

Jackson Turbidity Unit (JTU), 28, 29

Secchi disk, 27, 28

turbidity, 9, 22, 23, 27, 28, 29, 46, 48

wave action (effect of), 28, 46

Watcrway (9-foot), 4

Wooded shoreline (vegctation line), 7, 8, 39, 47 




\section{Some Publications of the ILLINOIS NATURAL HISTORY SURVEY}

\section{BULLETIN}

Volume 31, Article 7.-The Mecoptera, or Scorpionflies, of Illinois. By Donald W. Webb, Norman D. Penny, and John C. Marlin. August, 1975. 66 p., index.

Volume 31, Article 8.-An Electrofishing Surrey of the Illinois River, 1959-1974. By Ricliard E. Sparks and William C. Starrett. August, 1975. 64 p., index.

Volume 31, Article 9.-Pesticides and Environmental Quality in Illinois. By Robert L. Metcalf and James R. Sanborn. August, 1975. $56 \mathrm{p}$., index.

Volume 31, Article 10.-The Bantam Sunfish, Lepomis symmetricus: Systematics and Dis. tribution, and Life History in Wolf Lake, Illinois. By Brooks M. Burr. September 1977. 30 p., index.

\section{BIOLOGICAL NOTES}

103.-The Types of Collembola (Insecta) at the Illinois Natural History Survey. By José A. Mari Mutt. February 1978. 7 p.

104.-A Summary of the Life History and Distribution of the Spring Cavefish, Chologaster agassizi Putnam, with Population Estimates for the Species in Southern Illinois. By Philip IV. Smith and Norbert M. Welch. May 1978. 8 p.

105.-Distribution and Abundance of the Gray Squirrel in Illinois. By Charles M. Nixon, Stephen P. Havera, and Robert E. Green. berg. June 1978. $55 \mathrm{p}$.

106.-The Life History of the Cypress Darter, Elheostoma procliare, in Max Creek, Illinois. By Brooks M. Burr and Lawrence M. Page. July 1978. 15 p.

107.-Soybean Spiders: Species Composition, Population Densities, and Vertical Distribution. By Charles D. LeSar and John D. Unzicker. July 1978. 14 p.
108.-The Nest Biology of the Bees Andrena (Melandrena) regularis Malloch and Andrene (Melandrena) carlini Cockerell (Hymenoptera: Andrenidae). By Martha Northam Schrader and Wallace E. LaBerge. August 1978. $24 \mathrm{p}$.

109.-Illinois Birds: Ciconiiformes. By Jean W. Craber, Richard R. Graber, and Ethelyn L. Kirk. August 1978.80 p.

110.-Illinois Birds: Sylviidae. By Jean W. Graber, Richard R. Graber, and Ethelyn L. Kirk. July 1979. 22 p.

111.-Monitoring the Seasonal Appearance and Density of the Black Cutworm with a Virgin Female Trap. By Lynn Pautler, William G. Ruesink, Hans E. Hummel, and William H. Luckmann. July 1979. 7 p.

112.-The Life History of the Least Darter, Etheostoma microperca, in the Iroquois River, Illinois. By Brooks M. Burr and Lawrence M. Page. August 1979. 16 p.

\section{CIRCULAR}

47.--1llinois Trees and Shrubs: Their Insect Enemies. By L. L. English. May 1976 (Sixth printing, with revisions). $88 \mathrm{p}$.

49.-The Duncsland Heritage of Illinois. By Herbert H. Ross. August 1963 (Reprinted May 1974). 28 p.

51.-Illinois Trees: Selection, Planting, and Care. By J. Cedric Carter. March 1977 (Third printing). $123 \mathrm{p}$.

52.-Fertilizing and Watering Trees. By Dan Neely and E. B. Himelick. December 1971 (Third printing). $20 \mathrm{p}$.

54.-Corn Rootworm Pest Management in Canning Sweet Corn. By W. H. Luckmann, J. T. Shaw, D. E. Kuhlman, R. Randell, and C. D. LeSar. March 1975. 10 p.

List of available publications mailed on request

No charge is made for publications of the lluinois N.ITURaz IListory Surver. A single copy of most publications will be sent free to anyone recpuesting it until the supply becomes low. Costly publications, mote than one copy of a publication, and publications in short supply are subjects for special correspondence. Such correspondence should identify the writer and explain the use to be made of the publication or publications. 